UNIVERSIDADE DE BRASÍLIA

INSTITUTO DE LETRAS

DEPARTAMENTO DE LINGUÍSTICA, PORTUGUÊS E LÍNGUAS CLÁSSICAS PROGRAMA DE PÓS-GRADUAÇÃO EM LINGUÍSTICA

Sarah Freitas Rabêlo

SINTAGMAS LOCATIVOS NO PORTUGUÊS DE MOÇAMBIQUE E DO BRASIL: O PAPEL DO CONTATO DE LÍNGUAS 


\title{
SINTAGMAS LOCATIVOS NO PORTUGUÊS DE MOÇAMBIQUE E DO BRASIL: O PAPEL DO CONTATO DE LÍNGUAS
}

\author{
Dissertação apresentada ao Programa de Pós-graduação \\ em Linguística da Universidade de Brasília como \\ requisito parcial para obtenção do título de mestre em \\ linguística. \\ Área de concentração: Teoria e Análise Linguística. \\ Orientadora: Profa. Dra. Heloísa Maria Moreira Lima \\ Salles.
}




\section{SINTAGMAS LOCATIVOS NO PORTUGUÊS DE MOÇAMBIQUE E DO BRASIL: O PAPEL DO CONTATO DE LÍNGUAS}

Dissertação apresentada ao Programa de Pós-graduação em Linguística da Universidade de Brasília como requisito parcial para obtenção do título de mestre em linguística.

Comissão examinadora:

Profa. Dra. Heloísa Maria Moreira Lima Salles - UnB

Profa. Dra. Zenaide Dias Teixeira - UEG

Profa. Dra. Eloísa Nascimento Silva Pilati - UnB

Prof. Dr. Marcus Vinícius da Silva Lunguinho - UnB 
Ficha catalográfica elaborada automaticamente, com os dados fornecidos pelo(a) autor(a)

Rabêlo, Sarah Freitas

Rs Sintagmas locativos no português de Moçambique e do Brasil: o papel do contato de linguas / Sarah Freitas Rabêlo; orientador Heloíaa Maria Moreira Lima Salles. -. Brasilia, 2016.

99 p.

Dissertaçăo (Mestrado - Mestrado em Linguística) Universidade de Brasilia, 2016.

1. Locativos, 2, Preposiçăo, 3, Contato linguistico. I. Salles, Heloisa Maria Moreira Lima, orient. II. Titulo. 
Quando derem vez ao morro, todo o universo vai sambar. (Lenine) 


\section{AGRADECIMENTOS}

Primeiramente, agradeço aos meus pais o apoio, o incentivo e a confiança que depositaram em mim durante toda minha carreira escolar e vida acadêmica. Ao meu pai, agradeço o legado da curiosidade, da criticidade e da valorização aos estudos que me propiciou conquistar sonhos que ele tenha talvez projetado para si, mas não tenha alcançado por empecilhos decorrentes de sua própria condição social. Minha realização também é a sua, onde quer que o senhor esteja!

A minha mãe agradeço todo o amor incondicional que me foi transmitido sob diferentes formas nesses meus anos de vida. Mãe, a senhora é meu espelho! Espero recompensar todo o esforço que a senhora sempre fez por mim em forma de amor, proteção e carinho. Tu és a joia mais preciosa que tenho!

Ao meu namorado, Bryan, companheiro de todas as horas, agradeço a paciência comigo nesses quase 7 anos de UnB, especialmente nesses dois últimos meses. Sem você, meu amor, eu teria enlouquecido nesse período. Obrigada por me dar proteção, carinho e, sobretudo, por tentar compreender minha cabeça maluca! Espero conquistar mais e mais sonhos ao teu lado.

Às amigas da época do ensino médio, Evelyn e Bianca, agradeço por terem compreendido o motivo de minha ausência nos aniversários, nas colações de grau e em outros eventos importantes a que faltei devido aos estudos na UnB. Carrego vocês em meu coração.

A minha orientadora, profa. Dra. Heloísa Salles, agradeço por ser essa pessoa admirável que me forneceu inspiração profissional para despertar o interesse pelos estudos acadêmicos. Querida Helo, agradeço demais a sua confiança em meu trabalho e o estímulo que me deu para que eu não desistisse dessa conquista. Devo muito a ti!

Aos professores que compõem a banca examinadora, obrigada por terem aceitado esse convite-desafio.

Agradeço à profa. Dra. Eloísa Pilati pelo exemplo de ser humano que é. Você, professora, deixava as aulas de sintaxe formal muito mais descontraídas. Obrigada por tudo!

Ao prof. Dr. Marcus Lunguinho agradeço a inspiração profissional e a parceria que pudemos edificar nesse meu último ano do mestrado. Obrigada também pelas indicações bibliográficas e pelos ensinamentos em sala de aula, sem os quais eu não teria crescido tanto. 
Ao meu grande amigo inseparável, querido Rick. Obrigada pelos cafés que você preparou para mim nesses últimos dias (ou seriam noites?) para que eu aguentasse firme o tranco. Jamais me esquecerei do teu apoio.

Agradeço aos amigos da pós-graduação, Paula Guedes, Wagner Santos, Elisabete Ferreira e Manoel Pereira, pela troca de conhecimentos durante o curso. Muito obrigada, gerativos!

Agradeço às políticas públicas de inclusão que possibilitaram a mim e aos meus colegas da escola pública o acesso à universidade pública, sem a qual eu não seria a profissional e o ser humano que hoje sou.

Agradeço à CAPES pelo auxílio financeiro fornecido durante grande parte do período de pesquisa.

Não posso deixar de agradecer a Darcy Ribeiro por ter criado esse conceito humanístico de universidade. Nada mais honroso que ter estudado em um campus que carrega o nome desse grande brasileiro.

Agradeço, enfim, a todos os meus familiares e amigos que acreditaram que essa conquista seria possível, apesar das tantas dificuldades. Dedico tudo a vocês! 


\section{RESUMO}

O presente estudo investiga a realização dos sintagmas locativos no português de Moçambique (PM), focalizando o comportamento das preposições que os constituem, em uma perspectiva comparativa com o português brasileiro (PB) e o português europeu (PE) língua-alvo no processo de formação das variedades brasileira e moçambicana. $\mathrm{Na}$ análise dos dados do PM, extraídos do corpus elaborado por Gonçalves (1990), observou-se que, nessa língua, os sintagmas locativos preposicionados podem: (i) exercer função oblíqua, quando inseridos na estrutura argumental de verbos de movimento direcional (nem todos íamos na mesma escola / só voltei para aqui o ano passado) ou de verbos estativos (veio morar em casa dos meus pais / fui viver para o campo); (ii) ocupar posição de tópico (na beira saímos dia cinco); (iii) ocupar posição pré-verbal em predicados transitivos e (ou) existenciais (nas escolas não dão certificados de habilitação / em cada escola tinha capacidade para albergar seiscentos alunos / Na minha casa nunca teve dificuldade); (iv) ocupar posição pré-verbal em predicados copulativos com verbo "estar" (nesses museus está muito relacionados com a guerra de libertação / neste lugar está fora do coiso, está fora da cidade. Considerando a escolha da preposição, no contraste com a língua alvo, verifica-se que em (i), (ii) e (iii), o PM utiliza indistintamente a preposição 'em' introdutora do locativo, enquanto o PE utiliza sistematicamente as preposições 'a' e 'para', com verbos de movimento, e a preposição 'em' com predicados estativos. Nesse aspecto, o PM identifica-se com o PB, embora o uso da preposição 'em' seja ainda mais difundido no PM do que no PB. Assumindo o quadro teórico da gramática gerativa (Chomsky 1995), verifica-se que as três variedades (moçambicana, brasileira e europeia) licenciam as construções (i) e (ii), com o argumento locativo como oblíquo e na posição de tópico, respectivamente, de um predicado inacusativo biargumental, e somente o PM autoriza as construções em (iv). Em relação a (iii) e (iv), este estudo investiga a hipótese de que o PP é realizado na posição de sujeito como uma construção do tipo inversão locativa ou em uma posição pré-verbal acima de TP e abaixo de $\mathrm{CP}$, distinguindo-se os casos em que o predicado é transitivo, sendo o argumento externo ligado por um operador genérico ou realizado em posição pós-verbal, e existencial, em que o argumento externo está ausente. Propõe-se que, no contexto de contato linguístico que envolveu a aquisição do português como segunda língua (L2) em Moçambique e no Brasil, a opacidade dos traços provenientes do input do PE motivou a emergência de construções inovadoras, tanto por interferência da L1 (línguas Bantu em ambos os casos), como por acesso (parcial) à GU. Seguindo a hipótese de Gonçalves \& Chimbutane (2004), consideramos que o uso generalizado da preposição 'em' como introdutora de sintagmas locativos no PM seja decorrente do fato de que essa preposição tenha ganhado estatuto estritamente funcional nessa língua, o que implica que o Nome locativo seja introduzido por essa preposição, independentemente do tipo de predicado verbal em que ocorra, um padrão característico da marcação de locativos nas línguas Bantu. Com base em Tortora $(2006,2008)$, assume-se que o sintagma locativo preposicionado (PP locativo) possui uma projeção em camadas (PP shell), que inclui uma projeção funcional de aspecto. A variação verificada entre o PM, o PB e o PE decorre do tipo preposição realizada no sintagma aspectual (AspP) interno à projeção do $\mathrm{PP}$ locativo.

Palavras-chave: Locativo; Preposição; Contato linguístico. 


\begin{abstract}
The present study investigates the syntax of locative phrases in Mozambican Portuguese (PM), focusing on the syntactic behavior of the prepositions that introduce them, in a comparative perspective with Brazilian Portuguese (BP) and European Portuguese (EP) which are goal-languages in the development of the Brazilian and Mozambican varieties. In the analysis of MP data, which are extracted from Gonçalves' (1990) corpus, the following patterns are observed regarding locative prepositional phrases: (i) they may occur as obliques, when they are inserted in the argument structure of verbs of directional movement (nem todos íamos na mesma escola / só voltei para aqui o ano passado) and stative verbs (veio morar em casa dos meus pais / fui viver para o campo); (ii) they may occur in the topic position (na beira saímos dia cinco); (iii) they may occur in preverbal position in transitive and/ or existential predicates (nas escolas não dão certificados de habilitação / em cada escola tinha capacidade para albergar seiscentos alunos / Na minha casa nunca teve dificuldade); (iv) they may occur in preverbal position in copular constructions with "estar" (nesses museus está muito relacionados com a guerra de libertação / neste lugar está fora do coiso, está fora da cidade. Considering the choice of the preposition, it is observed that PM uses indistinctively the preposition em ('in') introducing the locative phrase, while EP uses systematically the prepositions $a$ and para ('to') with verbs of movement and the preposition em ('in'), with stative predicates. In this respect, then, MP is similar to BP, although the preposition em ('in') is even more widely used in the former than in the latter. Assuming the framework of generative grammar (Chomsky 1995), it is noted that the three varieties (either the Mozambican, the Brazilian and the European one) license the constructions in (i) and (ii), with the locative occurring as an oblique argument of a biargumental unaccusative predicate, or as topic phrase, respectively, while only MP allows the construction in (iv). Regarding (iii) and (iv), our hypothesis is that they may occur in a type of locative inversion construction or in a position above TP and below CP. In this respect, we distinguish transitive predicates, in which the external argument either is bound by a generic operator or is realized in a VS configuration, and existential predicates, in which the external argument is absent. The study proposes that in the acquisition of Portuguese as a second language (L2), both in Mozambique and in Brazil, the opacity of the input involved in language contact accounts for the emergence of innovative constructions, under L1 interference (Bantu languages both in Mozambique and Brazil; Indian languages in Brazil), among other factors. Following Gonçalves \& Chimbutane's (2004), we assume that the generalized use of the preposition em 'in' in locative phrases in MP is due to the fact that this preposition is a functional category in this language, locative Nouns being introduced by it, independently of the predicate in which they are found, a pattern that is characteristic of locative marking in Bantu languages. Following Tortora $(2006,2008)$, we assume that the locative phrase is projected in a PP shell, including an Aspectual functional head. The difference among MP, BP and EP is determined by the type of preposition that is merged in the aspectual phrase (AspP) internal to the locative PP shell projection.
\end{abstract}

Key-words: Locative; Preposition; Language contact. 


\section{SUMÁRIO}

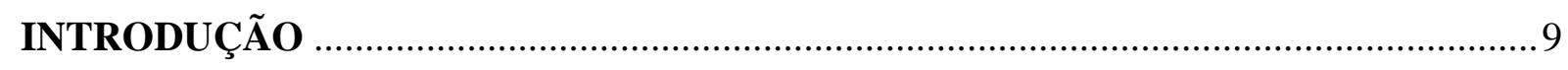

CAPÍTULO 1: METODOLOGIA E PRESSUPOSTOS TEÓRICOS ............................ 14

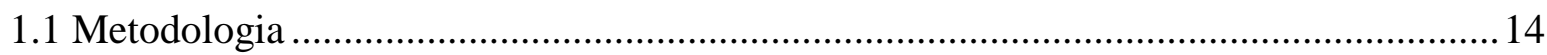

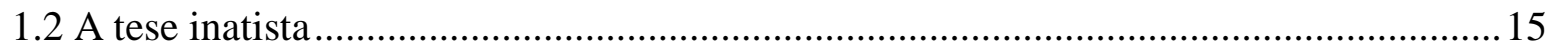

1.3 A situação linguística em Moçambique ...................................................................24

CAPÍTULO 2: ASPECTOS SEMÂNTICOS E SINTÁTICOS DOS PREDICADOS

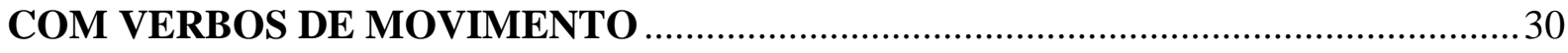

2.1 Estrutura argumental dos verbos de movimento................................................... 30

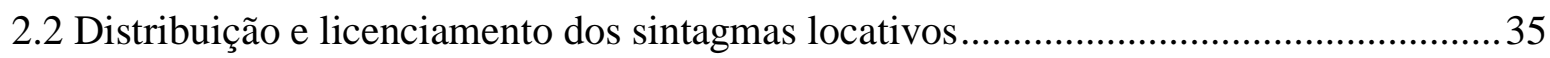

2.3 O papel das preposições no licenciamento dos sintagmas locativos em estruturas com

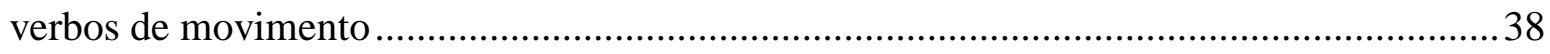

CAPÍTULO 3: ASPECTOS SINTÁTICOS E SEMÂNTICOS DOS SINTAGMAS LOCATIVOS NO PORTUGUÊS DE MOÇAMBIQUE: UMA ANÁLISE COMPARATIVA COM DADOS DO PORTUGUÊS DO BRASIL ..............................43

3.1 PPs locativos em predicados com verbos de movimento ........................................43

3.2 PPs locativos como uma projeção em camadas (PP shell) .........................................50

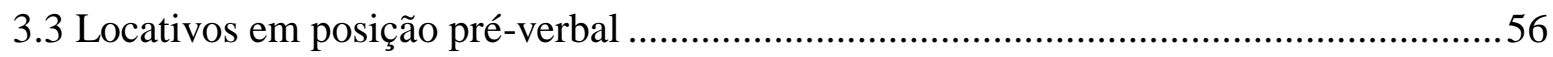

3.3.1 PPs locativos em posição pré-verbal em predicados com cópula ...........................71

CAPÍTULO 4: ARGUMENTOS LOCATIVOS NA VARIEDADE BRASILEIRA E EM VARIEDADES AFRICANAS DA LÍNGUA PORTUGUESA: A HIPÓTESE DO

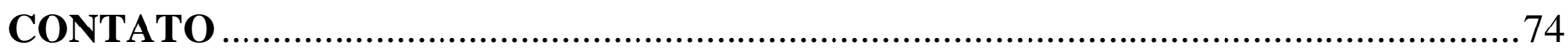

4.1 Aproximações entre o português brasileiro e línguas africanas...................................74

4.2 Realização sintática do Locativo em outras variedades africanas do português ............83

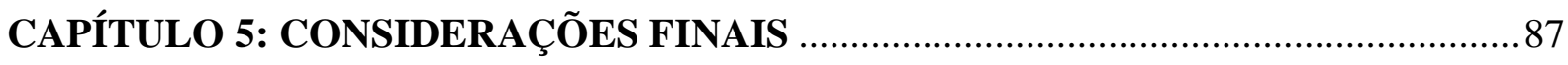

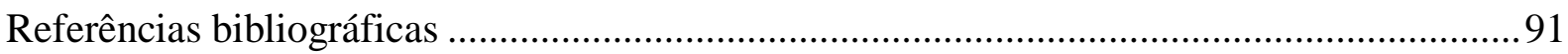





\section{INTRODUÇÃO}

Moçambique é um dos países africanos que, após o regime colonial português, passaram a adotar a língua portuguesa como língua oficial. Sendo Moçambique um país multilíngue, com mais de 40 línguas nativas em sua extensão territorial, um efeito da ação política de adotar o português como língua oficial é que o processo de implantação da língua do colonizador levou a uma situação de contato linguístico, envolvendo troncos linguísticos distintos, em que adultos falantes majoritariamente de línguas Bantu (LB) foram expostos, por hipótese, a um processo de transmissão imperfeita, que gerou formas inovadoras, as quais deram origem à variedade do português falada no país. Essa abordagem é adotada em vários estudos linguísticos na análise das propriedades lexicais (cf. Ngunga, 2009; Reite, 2013; entre outros) e sintáticas (cf. Carvalho 1991; Chimbutane, 1995; Gonçalves \& Sitoe, 1999; Brito 2002, 2008; Gonçalves, 2002; entre outros) que caracterizam o português de Moçambique $(\mathrm{PM})$.

Visando contribuir para a agenda de pesquisa que trata de propriedades sintáticas presentes na gramática do PM, mas não na do português europeu (PE), este estudo levanta, com fundamentação teórica pautada na Teoria de Princípios \& Parâmetros (doravante P\&P) (cf. Chomsky, 1986, 1995), argumentos para explicar o comportamento sintático-semântico das preposições nos sintagmas com papel temático locativo no PM.

Além de muitas das construções do PM serem divergentes dos padrões de marcação locativa encontrados no PE, como se nota pelos dados em (1), o PM distingue-se da variedade europeia por licenciar estruturas com sintagma locativo preposicionado (doravante PP locativo) em posição pré-verbal em predicados transitivos, sem pausa antes do verbo nem marcas que evidenciem a omissão do sujeito da sentença (2), e em predicados copulativos com verbo "estar" (3):

(1) a. "vem matinê dançante no Zambi"

$$
\left(\mathrm{PB}^{\mathrm{ok}} / \mathrm{PE}\right. \text { : vem ... ao Zambi) }
$$

b. "chegamos até no Maputo"

$$
\left(\mathrm{PB}^{\mathrm{ok}} / \mathrm{PE}\right. \text { : chegamos ... (até) a Maputo) }
$$

c. "em janeiro arrancamos para cá em Maputo"

(?PB / PE: ... arrancamos (para) cá para Maputo)

d. "fui colocado para a faculdade de educação" 
$\left(\mathrm{PB}^{\mathrm{ok}} / \mathrm{PE}:\right.$... na faculdade $)$

e. "quando vim viver cá para o Maputo"

$\left(\mathrm{PB}^{\mathrm{ok}} / \mathrm{PE}\right.$ :... (cá) em Maputo)

(2) "nas cartas de amizade admite quase todo o tipo de linguagem"1

$\left(\mathrm{PB}^{\mathrm{ok}} / \mathrm{PE}\right.$ : nas cartas de amizade, admite-se...)

(3) "neste lugar está fora do coiso, está fora da cidade" (*PB / *PE)

(Gonçalves, 1990)

Nota-se que a seleção da preposição “em", nos dados em que constam verbos de movimento $^{2}(1 \mathrm{a}-1 \mathrm{c})$, tornam tais sentenças agramaticais no $\mathrm{PE}$, cujo padrão de seleção preposicional nesses contextos prevê "a" ou "para". No sentido inverso, a preposição "para", em $(1 \mathrm{~d}-1 \mathrm{e})$, foi selecionada em um contexto para o qual o PE prevê "em".

Segundo Costa (2010), a sentença em (2) só ocorreria no PE se houvesse pausa marcada ao final do PP locativo ou se fosse dada ênfase ao PP locativo, de modo a marcar seu posicionamento como tópico na sentença. Divergindo do PE e aproximando-se do PM, o português brasileiro (PB) aceita esse tipo de construção e ainda licencia construções em que o locativo funciona como sujeito da sentença, o que na literatura tem sido denominado de tópico-sujeito (cf. Pontes, 1986, 1987; Galves, 1998; Pilati, 2006; entre outros).

Construções como a apresentada em (3), por outro lado, além de serem totalmente agramaticais e imprevistas no PE, não foram detectadas nos estudos do PB consultados como referência bibliográfica nesta pesquisa, o que suscita questionamentos a respeito também das possíveis diferenciações entre PM e PB. Embora o sujeito locativo seja encontrado, em diferentes línguas, em estruturas equativas de predicado locativo com auxiliar "ser", os dados do PM se distinguem por predicarem de um locativo em estrutura com o verbo "estar".

\footnotetext{
${ }^{1}$ Dado de registro escrito recolhido do corpus organizado por Gonçalves (1990, p. 734).

2 Assim como Eugenio Souto (2014) fez em seu estudo, neste trabalho adota-se a expressão "verbo de movimento" em referência aos verbos que denotam movimento direcional, os quais não devem ser confundidos com verbos de modo de movimento, como nadar, atravessar, que são verbos que descrevem o movimento de um objeto pelo ponto de vista do modo como se dá o movimento, sem que haja a descrição de uma trajetória ou a indicação de uma direção do movimento.
} 
Entretanto, outros dados do PM demonstram que também há possibilidade de uso convergente com o PE no que se refere à realização dos sintagmas oblíquos locativos:

(4) a. "e tornou a regressar para a casa do meu pai"

b. "tive que interromper de novo os estudos na casa do gaiato e voltar cá para a cidade"

c. "não tem quem lhe levar ao Zambi"

d. "fomos ao hospital fazer uma inspeção médica"

e. "conseguimos chegar até ao centro"

(Gonçalves, 1990)

Todas as sentenças acima apresentam sintagmas locativos estruturados em conformidade com os padrões do PE, o que significa que os falantes do PM captam as propriedades de seleção próprias da língua-alvo, mas, por algum motivo, marcam padrões diferentes na maioria das vezes. Importa salientar que construções como as apresentadas em (4) são registradas em menor número que algumas das apresentadas em (1), conforme constatado por Gonçalves \& Chimbutane (2004). Inclusive, registram-se casos em que um mesmo falante realiza o locativo de acordo ora com o padrão do PE, ora com o do PM, em um único período, como exemplificado a seguir:

(5) "quando chegaram a Palmares chegaram no meio da mata de Palmares"

(Gonçalves, 1990, p. 553)

Com relação especificamente aos locativos com função oblíqua, a estrutura argumental dos verbos de movimento e as preposições selecionadas nesses contextos são, aparentemente, os itens mais afetados na construção da sintaxe dos locativos no PM. A junção desses fatores de variação implica que as construções locativas do PM sejam, na maioria das vezes, desviantes em relação ao PE, mas semelhantes ao que se encontra no PB. Diversos pesquisadores têm postulado que as propriedades que aproximam o PB e o PM, mas que distanciam ambas do PE, decorre do contato de línguas envolvido na formação das variedades brasileira e moçambicana (cf. Galves, 2008; Oliveira, 2008; Petter, 2007, 2008, 2009; Rabêlo \& Salles, 2013; Baxter, Mello \& Santana, 2014; entre outros). 
Tendo em vista a hipótese de que a variação linguística no PM decorre do contato entre línguas tipologicamente distintas, nosso objetivo primordial neste estudo é o de investigar as características das construções em que se verificam alterações na estrutura argumental e na estrutura interna do PP locativo, tendo como referência tanto análises prévias dos fenômenos pertinentes ao PM (cf. Duarte et. al., 1998; Gonçalves, 2002; 2005; Gonçalves \& Chimbutane, 2004; Brito, 2008; entre outros) quanto estudos que tratam de construções que guardam semelhança com os fenômenos do PM encontradas no português brasileiro (PB) (cf. Galves, 1998; Farias, 2006; Pilati 2006; Araújo, 2008; Avelar \& Cyrino, 2008; Avelar, 2009; Pilati \& Naves 2010, entre outros) $)^{3}$.

Utilizando o aporte teórico supramencionado, parte-se do pressuposto de que os falantes moçambicanos, frente ao contexto de aquisição de língua ambíguo e com escassez de input proveniente do contato com falantes nativos do PE, tanto recorrem às propriedades gramaticais de suas L1 quanto marcam novos valores paramétricos, indisponíveis no PE e nas respectivas L1, mediante um processo de reanálise das propriedades formais dos itens lexicais, processo esse estruturado, por hipótese, via acesso parcial à Gramática Universal (cf. White, 2003).

Os dados em (1) são tratados sob a hipótese de que a gramaticalização da preposição "em" nos predicados com verbos de movimento desencadeou um processo de expansão do emprego dessa preposição para outros tipos de predicados em que ocorre o sintagma locativo. Não se descartam, neste estudo, os casos em que são empregadas as preposições "para" e "a" nos mesmos contextos, mas a preocupação com o emprego da preposição "em" justifica-se por sua maior incidência nos dados examinados, bem como pelo fato de que a ocupação da posição de sujeito por PPs locativos está, por hipótese, associada à gramaticalização dessa preposição.

Frente aos dados, o presente estudo levantou as seguintes questões de pesquisa:

- O que motiva o emprego generalizado da preposição “em” no PM?

\footnotetext{
${ }^{3}$ Embora a análise translinguística seja sempre prioridade em uma pesquisa fundamentada nos pressupostos teóricos gerativistas, como é o caso do presente estudo, o recurso à bibliografia que, baseada nesses pressupostos, trata das construções locativas no PB, seja em função oblíqua ou de (tópico)-sujeito, foi praticamente a única forma de encontrar respaldo teórico que sustentasse uma argumentação referente aos dados do PM, uma vez que os estudos acerca dessa língua ainda são bem incipientes, pelo menos no que diz respeito às preposições.
} 
- Como explicar os dados em que sintagmas locativos ocupam a posição inicial da sentença, exercendo, aparentemente, a função de sujeito?

- Há alguma relação entre as propriedades gramaticais das línguas maternas — línguas Bantu — dos moçambicanos e a emergência desses fenômenos?

- Como explicar o licenciamento de certas construções, como a inversão locativa, no PB e no PM, mas não no PE? Essa aproximação entre PB e PM poderia ser explicada sob a hipótese do contato de línguas?

Com vistas a responder a tais questionamentos, o presente estudo está organizado da seguinte maneira: no capítulo 1, são expostos a metodologia de recolhimento dos dados e os pressupostos teóricos adotados para explicar o contexto de transmissão e aquisição do português em Moçambique; no capítulo 2, analisam-se a estrutura argumental dos verbos de movimento no português, o licenciamento dos sintagmas locativos e o papel das preposições nesses sintagmas, conforme os pressupostos da Teoria Gerativa; no capítulo 3, os dados do PM que foram recolhidos são submetidos a uma análise comparativa com dados do PB e de outras línguas que apresentam construções similares às detectadas no PM. Os dados estão organizados em seções próprias de acordo com a função/posição que o PP locativo exerce/ocupa na sentença; no capítulo 4, estabelece-se de que forma a literatura vem vinculando os fenômenos encontrados no PM e no PB ao contato com línguas de origem africana, de maneira a apresentar a defesa de que as inovações gramaticais dessas variedades do português, em oposição ao PE, devem-se, em parte, ao processo de transmissão linguística ocorrido no Brasil e em Moçambique; por fim, no capítulo 5, apresenta-se a conclusão, em que consta a síntese dos resultados obtidos no estudo, bem como apontamentos para pesquisas futuras. 


\section{CAPÍTULO 1 METODOLOGIA E PRESSUPOSTOS TEÓRICOS}

Este capítulo delineia a forma como a base empírica do trabalho foi obtida, bem como os pressupostos teóricos adotados para tratar dos dados recolhidos do corpus selecionado. Por apresentar os pilares teóricos que sustentam a tese inatista, este capítulo é peça fundamental para o entendimento da hipótese de que o contato linguístico entre PM e LB impactou a emergência das construções presentes no PM, mas não no PE.

O capítulo está dividido da seguinte forma: na seção 1.1, trata-se da metodologia adotada para se proceder à coleta e à análise de dados do PM; na seção 1.2, são expostos os pressupostos da tese inatista, adotada neste estudo, a partir da qual argumentamos que o lócus da mudança gramatical é o processo de aquisição. Na apresentação da tese inatista, inclui-se uma apresentação sintética do aparato formal da Teoria Gerativa, na abordagem do Programa Minimalista (Chomsky, 1995); na seção 1.3, abordam-se aspectos da situação sociolinguística de Moçambique, com a finalidade de relacioná-la ao processo de formação da gramática do PM.

\subsection{Metodologia}

Os dados do PM analisados neste estudo foram extraídos do corpus elaborado por Gonçalves (1990), o qual foi utilizado pela autora em sua tese de doutoramento e se encontra disponível para acesso público no portal virtual "Cátedra de Português Língua Segunda e Língua Estrangeira"4, que reúne um robusto acervo bibliográfico de estudos acerca das variedades do português faladas em diferentes países do mundo.

O corpus é composto por dados de discursos orais obtidos em 39 entrevistas, concedidas por 40 inquiridos. De acordo com Gonçalves (1990), as entrevistas totalizaram 14 horas de gravação, o que, na versão transcrita, constitui 727 páginas. Foram obtidos também dados de escrita por meio de 70 redações elaboradas pelos mesmos participantes das entrevistas, mas apenas nove redações constam do referido corpus.

Foram consideradas relevantes para nossa pesquisa as sentenças finitas em que o predicado continha sintagma locativo. Todas as entrevistas e textos escritos foram lidos atentamente para que os dados selecionados pudessem fornecer evidências suficientes para se definir de que forma opera a sintaxe nos sintagmas locativos no PM. A partir do recolhimento

\footnotetext{
${ }^{4}$ Link do portal: http://www.catedraportugues.uem.mz/? target_=lista-bibliografia
} 
dos dados, procedeu-se a sua análise preliminar com base na literatura que trata mais pontualmente das preposições nos predicados com verbos de movimento e das construções com sintagma locativo pré-verbal. Tal base bibliográfica, constituída principalmente pelas pesquisas de Gonçalves (2002; 2005), Gonçalves \& Chimbutane (2004), Pilati (2006) e Avelar \& Cyrino (2008), forneceu também os dados das LB apresentadas na presente análise.

Depois de definidos os fenômenos detectados a partir da análise preliminar, passouse à consulta de uma bibliografia que, dentro dos pressupostos teóricos gerativistas, tratasse tanto dos verbos de movimento quanto das preposições e de seu papel na construção de sintagmas locativos em outras línguas, como o PB, uma vez que, sendo este estudo fundamentado em P\&P (cf. Chomsky, 1986), esperava-se encontrar construções iguais ou semelhantes em outras línguas, o que se confirmou nessa fase da pesquisa, em que a bibliografia consultada forneceu subsídios para o tratamento teórico dado aos dados aqui analisados.

Entre esses subsídios, inclui-se a perspectiva de análise dos dados mediante o estudo das preposições pela interface sintático-semântica, cuja vantagem teórico-metodológica reside no fato de que as preposições podem tanto ser núcleos de predicados, selecionando argumentos e apresentando projeção sintagmática, semelhante ao que fazem as categorias lexicais Nome e Verbo, quanto manifestar propriedades essencialmente gramaticais, estabelecendo relações de Caso, nos termos gerativistas, conforme se detalha na seção subsequente.

\subsection{A tese inatista}

A tese de que língua é uma faculdade inata do ser humano surgiu na década de 50, quando se discutia o fenômeno da aquisição de linguagem no âmbito da Linguística.

Rebatendo os behavioristas, que argumentavam ser esse processo baseado no princípio de estímulo-resposta-reforço, Chomsky (1959) levanta a hipótese de que todo ser humano, diferentemente de qualquer outro ser vivo, nasce dotado da capacidade de adquirir língua e atua ativamente nesse processo. A essa capacidade mental, biologicamente adquirida durante a evolução humana, Chomsky (1986) denomina de Faculdade da Linguagem (FL).

Assim como há no cérebro humano áreas especificamente destinadas ao desenvolvimento das habilidades sensório-motoras e articulatório-perceptuais, há também, por hipótese, um espaço destinado para a aquisição e desempenho das funções linguísticas, o que significa dizer que o cérebro humano é dotado de FL. 
A fim de explicar de que forma a FL atua na aquisição de língua, Chomsky postula o conceito de Gramática Universal (GU) - um dos componentes da FL. A GU compreende todas as possibilidades linguísticas combinatórias presentes nas línguas. Conforme essas possibilidades são fixadas, forma-se a gramática de uma língua específica. Assim, Chomsky considera que "o estado inicial compartilhado tem de ser bastante complexo para produzir cada língua, dada a experiência apropriada; mas não tão complexo que exclua alguma língua que os humanos possam atingir" (CHOMSKY, 1998, p. 20).

A partir desse pressuposto, o modelo da GU prevê a existência de: princípios gerais e comuns a todas as línguas do mundo; e parâmetros, que consistem em opções de variação a serem fixadas no contato com o input de uma dada língua. Nesse sentido, o processo de aquisição de língua é equivalente a uma especialização da GU, uma vez que, diante dos princípios, a GU prevê que os parâmetros sejam fixados, dando origem à representação de uma língua particular na mente do indivíduo. Esse é o fundamento da denominada Teoria de Princípios \& Parâmetros (P\&P), desenvolvida por Chomsky (1981, 1986), e na abordagem proposta no Programa Minimalista (CHOMSKY, 1995).

Considerando que, apesar da capacidade mental inata, é necessário que o ser humano esteja exposto aos dados da língua a ser adquirida, ou seja, é necessário o input linguístico, Chomsky explica que "cada língua é o resultado da atuação recíproca de dois fatores: o estado inicial e o curso da experiência" (CHOMSKY, 1998, p. 19). Dessa maneira, a aquisição da linguagem depende tanto dos processos mentais quanto dos estímulos externos.

Para esclarecer que, no entanto, o componente interno determina o papel que o componente externo assume no processo de aquisição de língua, Chomsky recorre ao argumento da pobreza do estímulo, de acordo com o qual a marcação dos valores paramétricos da língua produz um resultado que vai além do que o input provê, o que justifica que seja considerado pobre, e se confirma pela forma como se manifesta, com os truncamentos típicos da fala, as ambiguidades, especialmente em relação à avaliação do desempenho do aprendiz pelo interlocutor (que pode ser orientada para o conteúdo ou para a forma). Ou seja, mesmo com tantas imperfeições presentes no input, a criança adquire língua e, ainda em tenra idade, é capaz de produzir sentenças tão complexas quanto às produzidas por um falante adulto, sem necessariamente ter tido acesso às propriedades da língua pela experiência sensível do contato com o input. Dessa forma, conclui-se que o conhecimento linguístico adquirido é mais complexo do que o input que o indivíduo recebe. 
Adquirida a língua, o falante torna-se capaz de produzir sentenças infinitas, aplicando a criatividade e a recursividade para tanto.

Tendo isso em vista, os estudos em Gramática Gerativa ocupam-se das propriedades da língua no nível mental, buscando explicitar de que maneira a gramática das línguas interage com os princípios e os parâmetros da GU. No modelo minimalista, Chomsky (1995) postula que os sistemas de performance articulatório-perceptual e conceptual-intensional envolvidos na produção da fala ligam-se, respectivamente, às componentes Forma Fonológica (PF) e Forma Lógica (LF) da Faculdade da Linguagem, pelas quais as sentenças necessariamente devem passar para serem externadas. Antes de alcançar PF e LF, os objetos linguísticos perfazem alguns caminhos. No Minimalismo, entende-se que a Faculdade da Linguagem é composta pelo léxico ("vocabulário da língua”) e por um sistema computacional, responsável pela estruturação sintática das sentenças.

A partir do léxico são selecionados itens que o sistema computacional organiza como pares ordenados $(\pi, \lambda)$, cujos membros carregam traços que devem ser interpretados em PF e em LF, respectivamente. Para que uma sentença convirja ao final da computação, é necessário que ela apresente apenas traços interpretáveis nesses níveis de interface, conforme prevê o Princípio da Interpretação Plena. Para atender a esse princípio, uma série de operações sintáticas é acionada. A primeira delas é Select, que consiste em selecionar do léxico os itens necessários para a formação de uma sentença. Esse conjunto de itens lexicais denomina-se Numeração. Selecionados os itens, a Numeração é fechada, não sendo mais possível acessar novamente o léxico para acrescentar outros itens/traços lexicais na computação, conforme pressupõe a Condição de Inclusividade. Ou seja, somente os itens e seus traços presentes na Numeração passarão para as próximas fases da derivação. Em seguida, os objetos que compõem a Numeração sofrem Merge, operação binária que os concatena, de modo a formar objetos sintáticos maiores que podem ser combinados a outros objetos sintáticos já formados, até que se esgotem os itens da Numeração.

Em uma sentença como "João viu Maria”, ocorre primeiramente Merge entre o verbo e "Maria", que formam uma categoria intermediária (V'), a qual, por sua vez, realiza Merge com "João" e forma a projeção máxima $\mathrm{VP}^{5}$. Se houvesse um elemento adjunto, como o advérbio “ontem”, por exemplo, Merge atuaria concatenando esse adjunto à projeção máxima, formando uma representação arbórea como a que apresentamos a seguir:

\footnotetext{
${ }^{5}$ Uma vez que a ausência de $v$ P não compromete a explicitação acerca do conceito de Merge, preferimos adotar, naquele ponto especificamente, a estrutura mais simples, por motivos didáticos.
} 
(1)

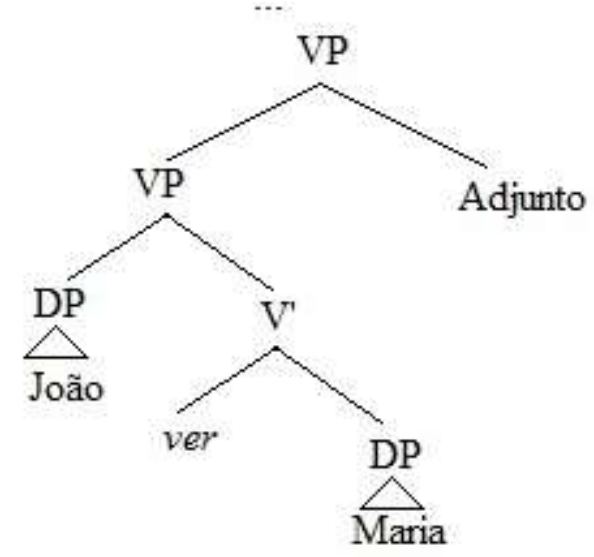

Nessa configuração atua também a operação Agree, que é responsável por estabelecer uma relação entre os traços formais dos itens que foram concatenados. No âmbito do Minimalismo, traços formais incluem traços de Caso (Nominativo, Acusativo, Dativo), traços categoriais (Determinante, Nome, Verbo, Preposição), traços de seleção (pertinentes apenas às categorias que predicam, como Verbo e Preposição) e traços de concordância das categorias funcionais (isto é, pessoa, número e gênero), além de traços semânticos e fonológicos.

Tendo em vista que, no modelo de Regência e Ligação (CHOMSKY, 1981), o Nominativo era o único Caso atribuído em uma relação entre núcleo e especificador (Spechead), no domínio de uma categoria funcional (no caso, IP), em oposição aos demais Casos, que eram atribuídos sob regência de um núcleo lexical, o Programa Minimalista buscou uma forma de unificar o licenciamento de DPs, assumindo que o Caso seria um by-product do processo de valoração de traços formais não-interpretáveis em um núcleo funcional, por traços formais interpretáveis em um núcleo lexical, referida como operação Agree. Em decorrência dessa demanda e devido a evidências de línguas que apresentam concordância verbal tanto com sujeito como com objeto, Chomsky (1991) refina a proposta de cisão do IP inicialmente proposta por Pollock (1989 apud Chomsky, 1991), delimitando a operação de checagem de Caso à relação Spec-head, dentro de uma projeção sintagmática como a seguinte: 
(2)

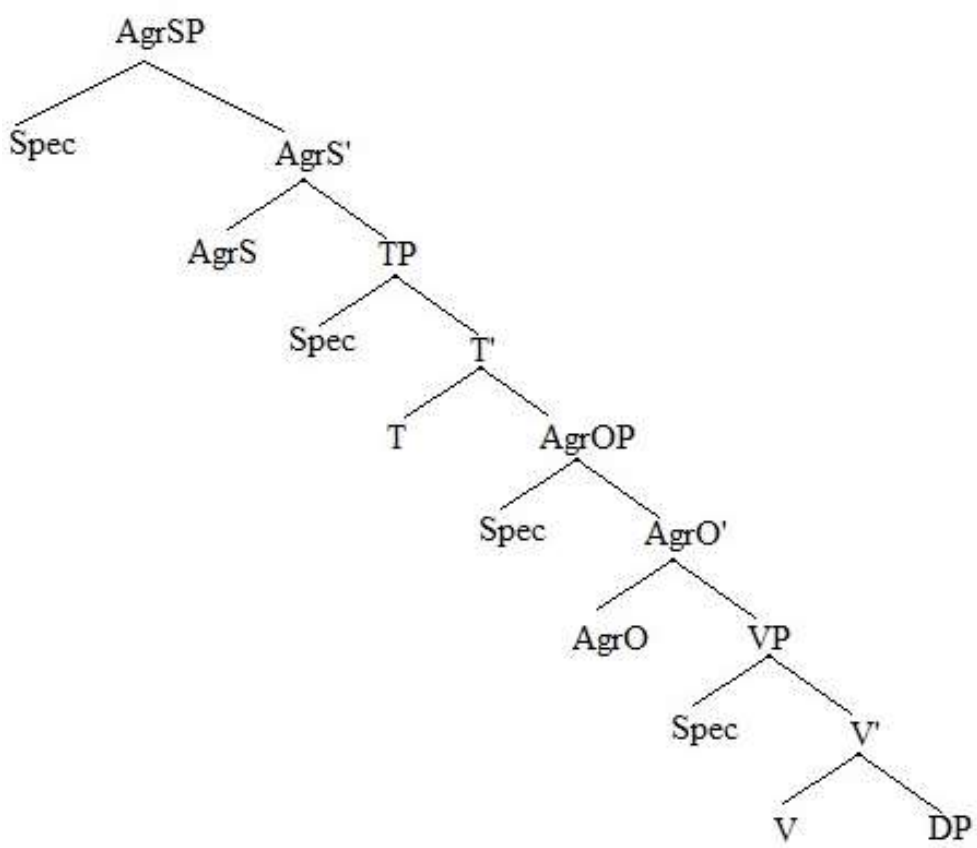

Nessa projeção, os núcleos funcionais AgrS e AgrO são os responsáveis pelo licenciamento do traço formal de Caso dos DPs, que é validado como Nominativo e Acusativo, respectivamente, em cada núcleo funcional. Por hipótese, mesmo línguas que não apresentam concordância com o objeto, movimentariam o DP para Spec-AgrO, com a ressalva de que, nesse caso, o movimento seria encoberto, uma vez que a diferença entre o movimento encoberto e o explícito reside apenas nos traços de concordância dos DPs em cada língua, que podem ser fortes (movimento explícito) ou fracos (movimento encoberto).

Com o Programa Minimalista, Chomsky (1995) entende que a assunção de uma projeção tão complexa como (2) atende mais aos constructos inerentes à teoria que ao critério de economia no qual se acredita que o processamento linguístico é pautado. Resgatando, então, a proposta de Hale e Keyser (1993 apud Chomsky, 1995), o Programa Minimalista propõe uma representação em que o VP é explodido em camadas, o denominado modelo $V P$ shell ${ }^{6}$ :

\footnotetext{
${ }^{6}$ A criação dessa representação decorreu também da discussão empreendida por Larson (1988) acerca da projeção dos dois argumentos internos selecionados por verbos dativos de transferência, como na sentença "João deu um presente a Maria". Com base no modelo VP-shell, entende-se que: o argumento Alvo [a Maria] é licenciado em Compl- $\mathrm{V}$, onde terá seu Caso atribuído pela própria preposição que projeta o $\mathrm{PP}$; o argumento Tema [um presente] é licenciado em Spec-VP; e o argumento externo, licenciado em Spec- $v$ P.
} 
(3)

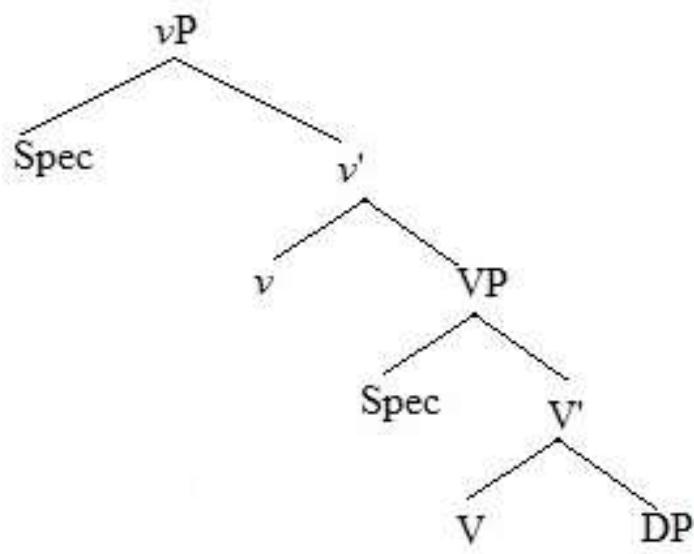

(HORNSTEIN; NUNES; GROHMANN, 2005, p. 122)

A partir dessa representação, assume-se que o verbo leve (v) é responsável pela atribuição do papel temático ao argumento externo e pela valoração do traço formal de Caso do argumento interno, que pode ser movido para o especificador de $v \mathrm{P}$, na sintaxe aberta, ou permanecer in situ, uma opção determinada no nível paramétrico. No nível de IP/TP, é realizada a valoração do traço de Caso nominativo, com a realização do DP na posição de especificador. Diante disso, o núcleo de VP (isto é, V) é responsável pela marcação do papel temático interno, sendo a verificação dos traços formais dos DPs que realizam esses argumentos verificados no nível das projeções funcionais.

Tanto os traços de concordância (doravante traços- $\phi$ ) quanto traços de Caso são valorados mediante Agree, em uma relação (dita match) entre um elemento Sonda e um elemento Alvo. Funcionam como Sonda as categorias funcionais com traços- $\phi$ não interpretáveis, que devem ser valorados antes que os objetos sintáticos passem para LF e PF. Como DPs carregam traços- $\phi$ interpretáveis, estes funcionam como Alvo, valorando e eliminando os traços não interpretáveis da Sonda.

Há casos em que Agree não é suficiente para valorar determinados traços formais, por isso a operação Move é requerida. Com essa operação, os sintagmas são movimentados na estrutura para que a checagem de traços não interpretáveis seja efetuada. É o que ocorre, por 
exemplo, em português, na verificação de traço $\mathrm{EPP}^{7}$, alocado no especificador da Sonda em T.

No inglês, por exemplo, há duas formas de checagem do traço EPP: por Merge, mediante a inserção de um expletivo (4a); ou por Move, que desloca o DP "a man" para Spec$\mathrm{TP}$, onde se encontra o traço EPP à espera de ser valorado (4b):

(4) a. [TP $\left[\right.$ Spec-T there $\left[\operatorname{arrived}_{\mathrm{k}}\left[\mathrm{vP}\left[\mathrm{v}, \mathrm{t}_{\mathrm{k}}[\mathrm{DP}\right.\right.\right.$ a man $\left.\left.\left.\left.\left.]\right]\right]\right]\right]\right]$

b. $\left[\mathrm{TP}\left[\right.\right.$ Spec-T $_{\mathrm{T}}$ a $\left.\left.\operatorname{man}_{\mathrm{i}}\left[\operatorname{arrived}_{\mathrm{k}}\left[\mathrm{vP}\left[\mathrm{V}, \mathrm{t}_{\mathrm{k}}\left[\mathrm{DP} \mathrm{t}_{\mathrm{i}}\right]\right]\right]\right]\right]\right]$

(HORNSTEIN; NUNES; GROHMANN, 2005, p. 212)

Sendo a operação em (4a) mais econômica que a apresentada em (4b), pode-se entender que aquela é preferível a esta, tendo em vista a hipótese minimalista de que o sistema computacional é conservador.

Depois de valorados os traços não interpretáveis, ocorre, em um ponto da derivação, Spell-out, que envia à PF o que for interpretável nesse nível, seguindo a derivação para LF, que interpreta as informações relevantes para o componente semântico. Considera-se que, até Spell-out, as operações acontecem na chamada sintaxe aberta e geram efeitos tanto em LF quanto em PF. Quaisquer operações que ocorram após Spell-out acontecem na chamada sintaxe encoberta e são acessíveis apenas para LF.

A seguir está representado o esquema que demonstra a perspectiva minimalista do sistema computacional que opera as operações sintáticas supramencionadas:

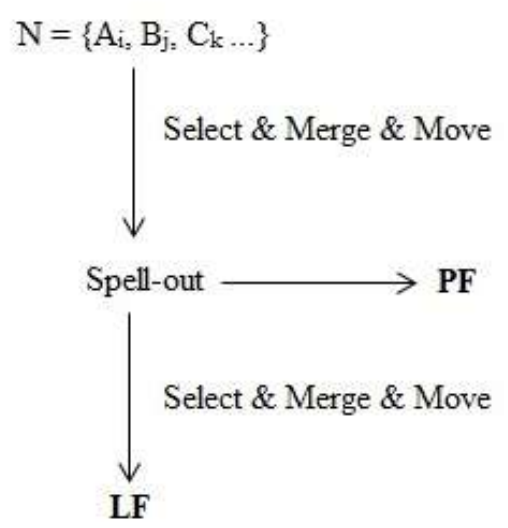

(HORNSTEIN; NUNES; GROHMANN, 2005, p. 73)

\footnotetext{
${ }^{7}$ EPP refere-se a Princípio de Projeção Estendida (EPP), criado por Chomsky (1991) para explicar que toda língua preenche a posição de sujeito, seja por uma categoria fonologicamente realizada, seja por uma categoria nula.
} 
No tocante às categorias que participam da computação, entende-se que todo processo de derivação é guiado pelas categorias funcionais, cujos traços não interpretáveis são valorados por categorias lexicais. Em vista disso, sabe-se que a aquisição de categorias funcionais e lexicais demanda diferentes condições. O mesmo acontece com relação às preposições de estatuto funcional e as de estatuto lexical, conforme menciona Littlefield $(2005)^{8}$ :

\begin{abstract}
In a study examining five- to eight-year-old children's reaction times to open versus closed class items, Friederici (1983) again investigated the divided nature of prepositions. Using a word-monitoring task, she found that children reacted significantly more slowly when presented with syntactic prepositions than lexical ones. This was more pronounced in the youngest children, but was still apparent in the oldest group. Additionally, the younger children had more difficulty responding to the functional prepositions, and didn't respond to the syntactic ones as often as the lexical ones. (LITTLEFIELD, 2005, p. 3)
\end{abstract}

Nesse sentido, afirma-se que, assim como as categorias funcionais $\mathrm{C}$ (Complementador, do inglês Complementizer), $\mathrm{T}$ (Tempo, do inglês Tense) e D (determinante, do inglês, Determiner), as preposições de estatuto funcional apresentam aquisição mais tardia que as lexicais. Além disso, Littlefield (2005) menciona estudos que apontam maiores taxas de erros registradas no uso de preposições funcionais que lexicais em contexto de aquisição. Para o autor, o motivo de tais resultados decorre do forte conteúdo semântico das preposições lexicais em contrapartida ao esvaziado do conteúdo semântico das preposições funcionais.

Considerando-se que a variação translinguística, bem como a mudança linguística, ocorre no contexto de aquisição de língua (cf. Roberts, 2007), é razoável supor que os contrastes apresentados pelos dados do PM em contraste ao PE, no que se refere ao comportamento das preposições, relacionam-se ao processo de aquisição do português como segunda língua (L2) pelos moçambicanos, oferecendo ainda evidência quanto ao estatuto da preposição no que se refere à distinção entre categorias funcionais e lexicais.

\footnotetext{
8 "Examinando, em um estudo, o tempo de reação de crianças com idade entre cinco e oito anos aos itens de classes abertas versus fechadas, Friederici (1983) investigou a natureza da divisão das preposições. Utilizando um teste de monitoramento de palavra, ela detectou que as crianças reagiam significativamente mais devagar quando apresentadas a preposições funcionais do que lexicais. Isso foi realizado mais entre as crianças pequenas, mas também apareceu no grupo dos mais velhos. Além disso, as crianças mais jovens tinham mais dificuldade de responder a preposições funcionais e não responderam às funcionais com a mesma frequência que às lexicais." (tradução nossa)
} 
Acerca desse assunto, Gonçalves (2002), com base em P\&P, considera que a aquisição de língua é um processo que envolve aprendizagem de material lexical e marcação das propriedades abstratas e primitivas (ou seja, parâmetros) de um dado sistema gramatical. Dessa forma, além de a marcação de um único parâmetro ser capaz de demarcar um conjunto de propriedades específicas de determinada língua, os efeitos gerados a partir da marcação de um único parâmetro se propagam por todo o sistema gramatical da língua, o que, na literatura, já fora denominado por Lightfoot (1991 apud Gonçalves, 2002, p. 327) como "natureza catastrófica da aquisição de língua".

Tomar tais pressupostos implica, sobretudo, considerar que a marcação de um parâmetro na L1 gera sérias consequências para a marcação de parâmetros de L2. Por isso, Gonçalves (2002) destaca o papel crucial que L1 tem no desenvolvimento de L2 e considera que o conhecimento do falante acerca de sua L1 funciona como guia para a aquisição de L2. Em outras palavras, isso significa dizer que os triggers ("gatilhos") que desencadeiam a aquisição do português de Moçambique, desde seus primórdios, são, de acordo com a hipótese da autora, analisados com base nos parâmetros das L1/LB, sendo isso responsável por algumas das características gramaticais que o PM, mas não o PE, apresenta.

Assim, determinadas estruturas do PE passam a ser ambíguas, ou seja, têm mais de uma descrição gramatical possível apenas para quem as adquire como L2 e tem L1/LB, como no caso dos moçambicanos. Embora haja diversas discussões acerca do papel da GU no processo de aquisição de L2, Gonçalves não se posiciona acerca dessa questão, apenas cita e considera o modelo de acesso total/transferência total, de Schwartz e Sprouse (1996 apud Gonçalves, 2002), uma "hipótese forte" (Gonçalves, 2002, p. 328).

White (2003), por sua vez, levanta a hipótese de que o processo de aquisição de L2 é desencadeado via acesso parcial à GU. Esse modelo de análise concebe que o estágio final da aquisição de L1 é o ponto de partida do processo de aquisição de L2. Isso significa que os parâmetros já marcados na L1 do falante interagem com os princípios da GU na aquisição de L2, de maneira que as sentenças reproduzidas em uma dada língua adquirida nessa situação ora convergem com a gramática da L1, ora convergem com a gramática da língua-alvo, ora apresentam construções inovadoras, inexistentes em L1 e na língua-alvo.

Devido ao espaço e tempo reduzidos, este estudo também não adotará um posicionamento em favor de uma ou outra hipótese, mas releva que essa discussão deve ganhar espaço em pesquisas futuras. 
Com base no que foi exposto nessa seção, defendemos que as propriedades formais das preposições, ao serem reanalisadas no processo de aquisição do PM, promovem o desencadeamento de valores paramétricos que se distinguem daqueles que determinam o padrão europeu, gerando, por consequência, sentenças como as presentes nos dados que são objeto de análise da presente pesquisa.

\subsection{A situação linguística em Moçambique}

Localizado na região sudeste do continente africano, Moçambique é um dos tantos países africanos que foram colônia de Portugal até meados do século XX. Atualmente, possui uma população total de 24.042.000 habitantes, dos quais apenas 59\% são alfabetizados, de acordo com o Ethnologue (Lewis et al, 2016). Estima-se que em Moçambique sejam faladas 43 línguas, entre as quais se incluem as diversas línguas autóctones da família Bantu, faladas pela maioria da população, e o português, herança do período colonial.

A distribuição das LB pelo território moçambicano está representada no mapa abaixo, fornecido pelo Ethnologue. A legenda designa cada LB por um número e demonstra, no número entre parênteses, quantas vezes uma mesma língua aparece em diferentes regiões do território moçambicano.

\footnotetext{
9 Ethnologue é um catálogo virtual que disponibiliza informações acerca das línguas faladas em diferentes regiões de cada país do mundo. O foco principal desse catálogo é fornecer dados estatísticos sobre aspectos sociolinguísticos (número de falantes, localização geográfica, genética das línguas etc.) relacionados a línguas minoritárias, como é o caso das línguas nativas africanas.
} 
Mapa 1 - línguas Bantu faladas no território de Moçambique

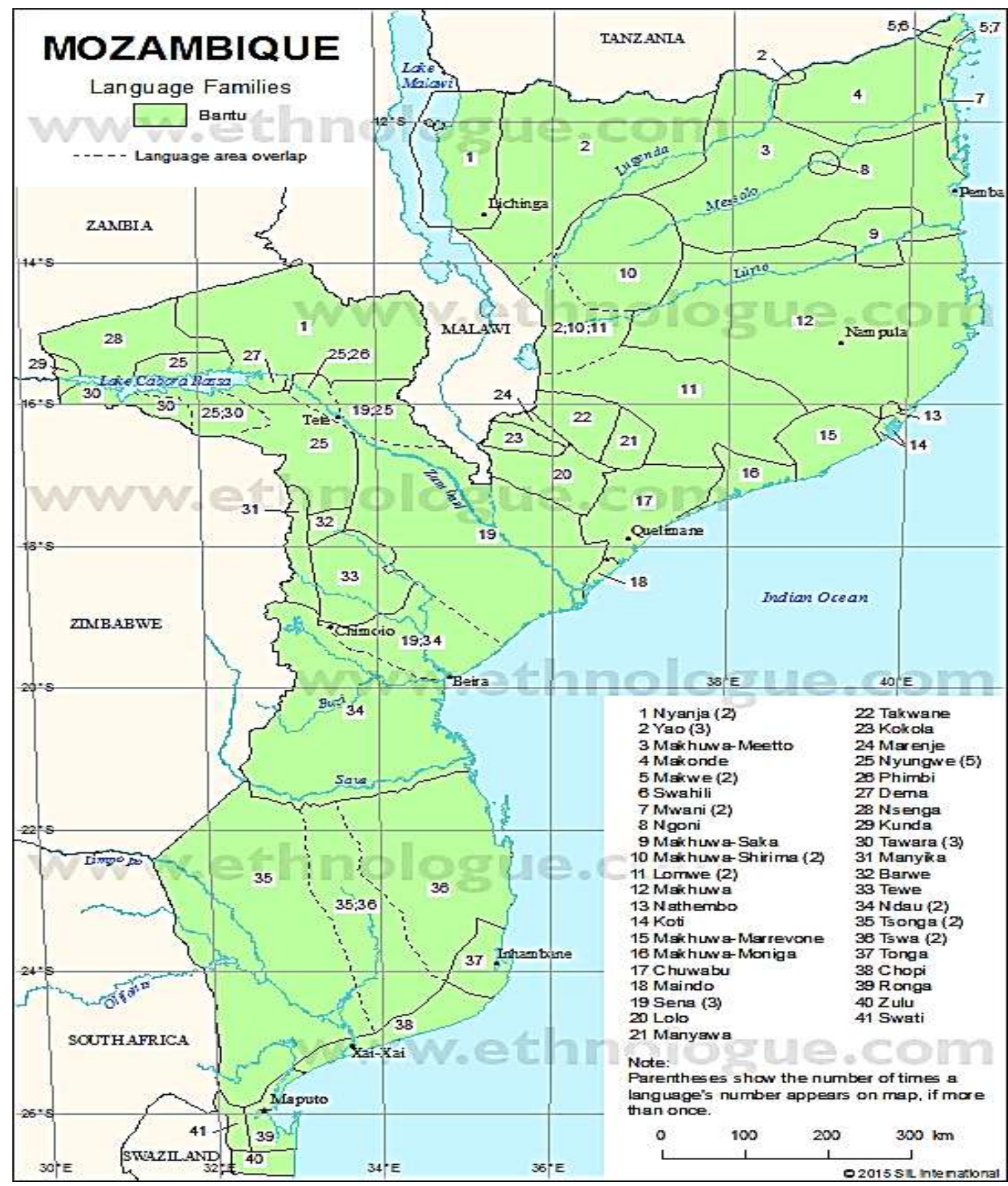

Fonte: página virtual do Ethnologue $e^{10}$

Um dos primeiros estudos acerca da diversidade linguística de Moçambique foi realizado por Guthrie, entre 1967 e 1971, que organizou as LB faladas no território moçambicano em quatro zonas linguísticas, de acordo com as propriedades diferenciadoras e compartilhadas entre as línguas registradas, como esclarece Firmino (2000). Com o objetivo

${ }^{10}$ Disponível em: http://www.ethnologue.com. 
de complementar esse enquadramento e determinar a correspondência entre as línguas e as regiões em que elas eram faladas, Firmino (2000, p. 2) menciona que se seguiram à pesquisa de Guthrie o Recenseamento Geral da População e Habitação (RGPH) realizado em 1997, o estudo de Nelimo (1989) e o estudo de Sitoe \& Ngunga (2000).

Firmino (2000) explicita que a adoção do português como língua oficial, após a independência de Moçambique, justificou-se pela necessidade de um símbolo nacional que fosse capaz de padronizar a comunicação geral e unificar a identidade do povo moçambicano, uma vez que cada uma das diversas línguas autóctones concentra-se em regiões específicas do país. Observa que:

\footnotetext{
(...) nenhuma das línguas autóctones cobre todo o território nacional, sendo por isso que não se reconhece uma língua franca, para além do português, que, apesar de não ser conhecido por todos os moçambicanos, ainda assim é a língua com falantes distribuídos por todo o país, principalmente nas camadas escolarizadas. Por exemplo, o Makua, língua autóctone mais conhecida, é falada no norte de Moçambique, na província de Nampula e em parte das de Cabo Delgado, Niassa e Zambézia. Nas restantes partes de Moçambique, o uso de Makua não tem muito expressão. Por outro lado, o Tsonga, predominante no sul, apenas é amplamente falado nas províncias de Gaza e de Maputo. (FIRMINO, 2000, p. 3)
}

A tentativa de padronizar a comunicação entre os moçambicanos mostrou-se, no entanto, falha, porque expandiu a desigualdade entre as populações urbanas e rurais. Citando o RGPH de 1997, Firmino esclarece que apenas 6\% da população moçambicana tinha o português como língua materna, sendo esse percentual localizado exclusivamente em zonas urbanas. Ainda segundo o referido recenseamento, $72 \%$ dos inquiridos que habitavam zonas urbanas declararam saber falar português, ao passo que apenas $27 \%$ dos entrevistados em zonas rurais afirmaram o mesmo, o que demonstra a dificuldade de acesso da população rural à educação e, consequentemente, ao português, uma vez que, em Moçambique, a língua portuguesa é adquirida quase que exclusivamente por via instrucional.

Além disso, a aquisição do português como L1 é algo recente na sociedade moçambicana, pois, segundo Firmino, está entre 10 e 20 anos a faixa etária dos falantes de português como L1, sendo "insignificante" o número de recenseados com 50 anos ou mais que declararam ter conhecimento da língua oficial.

Nesse contexto, as línguas autóctones prevalecem como L1 da população moçambicana e continuam a ser as mais utilizadas no cotidiano. Por sua vez, o português, adquirido como L2, fica restrito a domínios institucionais, conforme destaca Firmino. 
Apesar disso, é importante ressaltar que se tem registrado aumento no número de falantes de português em Moçambique, como se pode detectar pela comparação dos danos recolhidos no Recenseamento Geral da População (RGP) realizado em 1980 e dos obtidos no RGPH de 1997, conforme apresentado no seguinte gráfico:

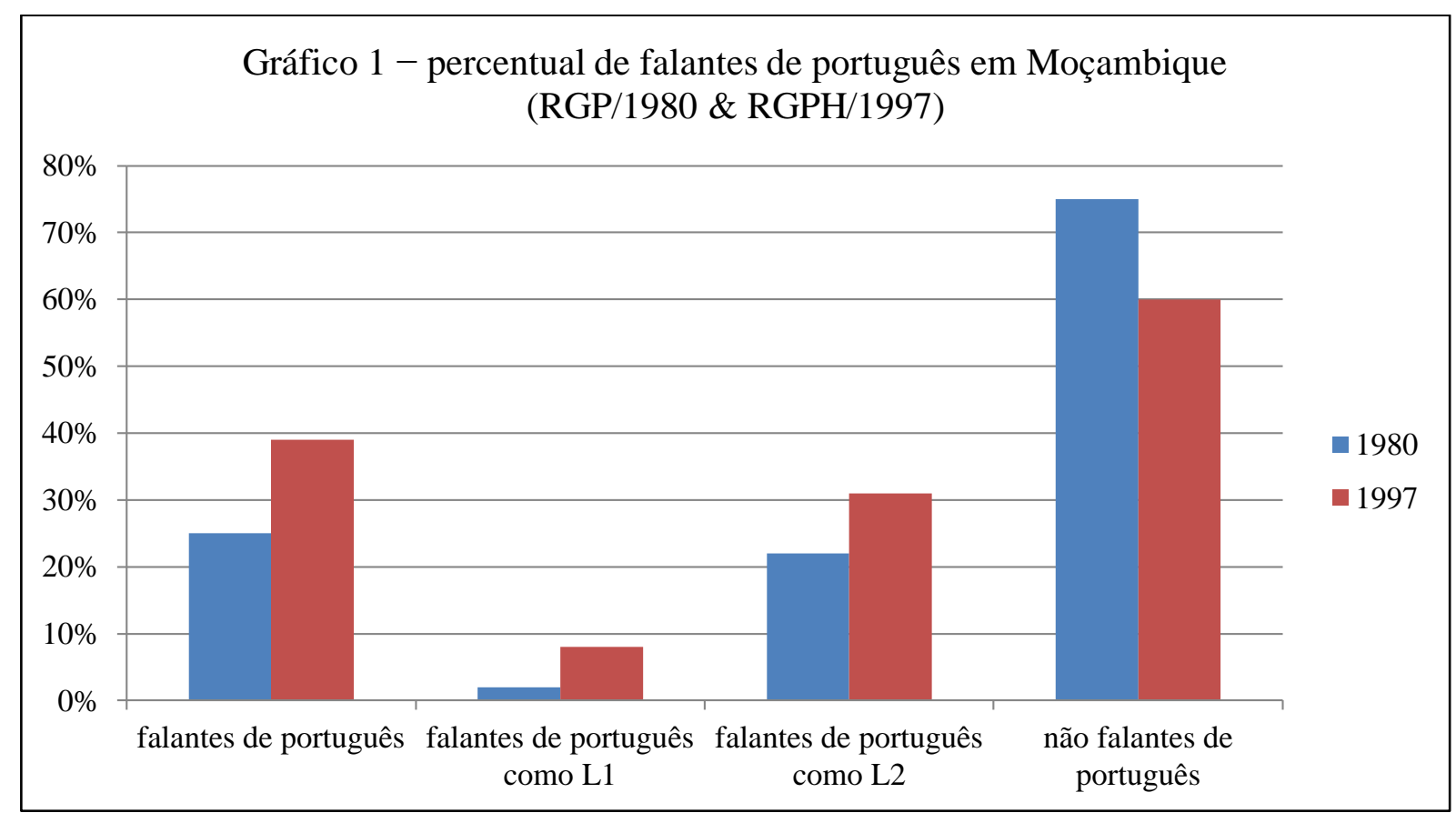

Fonte: FIRMINO, 2000, p. 11

Infere-se do gráfico que, no decorrer dos anos, o acesso da população moçambicana ao português vem sendo ampliado, tanto nos contextos de aquisição do português como L1 quanto nos de aquisição como L2, embora o percentual de moçambicanos que não falam português ainda seja demasiadamente alto - em torno de $60 \%$, segundo o gráfico.

O favorecimento à aquisição e ao uso do português em detrimento das línguas autóctones deve-se, principalmente, ao prestígio que a língua oficial vem ganhando, afirma Firmino (2000). O processo de migração do meio rural para as zonas urbanas contribui para a sobreposição da língua portuguesa em relação às línguas locais, o que Firmino considera prejudicial para o patrimônio linguístico e cultural de Moçambique.

Entretanto, é importante lembrar que o português falado em Moçambique constitui uma variedade bastante distinta da falada em Portugal. Firmino (2000) explica que, após a independência, houve uma massiva saída dos portugueses (antes colonos) de Moçambique. Consequentemente, o acesso aos padrões da língua-alvo foi comprometido em certa medida, o 
que acarretou uma série de efeitos de superfície na gramática da variedade do português formada em Moçambique. Por esse motivo, defende-se que as diversas particularidades encontradas no PM, mas não no português europeu (PE), relacionam-se com a forma com que a gramática do PM foi estruturada, uma vez que esse processo implicou o acesso aos dados disponíveis da língua-alvo e sua reestruturação a partir de propriedades gramaticais das L1 da população, ou seja, das LB.

Neste estudo, assumimos que o processo de formação do PM está envolvido em um contexto de transmissão linguística irregular, que configura uma situação prolongada de contato de línguas nativas com uma língua estrangeira eleita, politicamente, como dominante — um "ponto de referência" a partir do qual se forma uma nova variedade. Nesse contexto, forma-se uma nova variedade linguística que apresenta alterações em estruturas gramaticais provenientes da língua-alvo, as quais, devido à falta de clareza do input, são submetidas à reanálise, por vezes, apoiada nas propriedades da L1.

A hipótese da transmissão linguística irregular é proposta por Lucchesi (2003) na análise dos dados dialetais do PB. O autor postula que o contexto favorecedor dessa transmissão possui as seguintes características: i) um grupo minoritário monolíngue subjuga grupos quantitativamente maiores e linguisticamente diversos; ii) os indivíduos do grupo dominado são adultos aloglotas forçados a adquirir a língua do grupo dominante; iii) a situação de contato interlinguístico é prolongada, chegando a atingir gerações futuras do grupo dominado; iv) diante da falta de robustez do input da língua-alvo, o grupo dominado procede a reestruturações das propriedades desta (ou à marcação de novos valores paramétricos) com a finalidade de adquirir a língua; v) as inovações resultantes dessa estratégia de reestruturação/reanálise são passadas às gerações seguintes, que sedimentam uma nova variedade linguística da língua-alvo.

Nota-se que, em Moçambique, o contexto de aquisição do português envolveu exatamente as características elencadas acima, o que permite deduzir que as propriedades gramaticais encontradas no PM (e também nas LB), mas não no PE, sejam fruto de um processo de transmissão linguística irregular envolvido na formação inicial do PM. Importa ressaltar que esse processo não impede a aquisição dos parâmetros da gramática da línguaalvo, uma vez que o PM apresenta construções convergentes com o PE. No entanto, entendese que algumas estruturas ou mesmo traços formais de determinados itens lexicais da línguaalvo podem se tornar ambíguos para quem os adquire como L2. Em um contexto de transmissão linguística irregular, no qual o input à disposição do falante é reduzido, a 
aquisição é mediada pela reanálise das propriedades ambíguas, podendo o falante recorrer a valores paramétricos ainda não marcados ou marcados em sua L1 para resolver essa problemática. Assim, não se trata do processo de aquisição ser imperfeita, pressuposto incompatível com o que dispõe $\mathrm{P} \& \mathrm{P}$, mas sim de o contexto de acesso ao input envolver, por vezes, evidências fracas da L2 em contrapartida a evidências fortes da L1. 


\section{CAPÍTULO 2}

\section{ASPECTOS SEMÂNTICOS E SINTÁTICOS DOS PREDICADOS COM VERBOS DE MOVIMENTO}

Antes de proceder à análise dos dados do PM, faz-se necessário estabelecer os critérios classificatórios adotados neste estudo para designar as estruturas que compõem os predicados que comportam PPs locativos no português, de modo geral. Ou seja, o presente capítulo tem por objetivo apresentar estudos prévios sobre os PPs locativos e a estrutura sintática que os envolve, conforme realizadas na variedade dita padrão. O objetivo é definir um modelo de análise para que, no próximo capítulo, sejam investigadas as propriedades dos dados do PM, comparativamente aos dados do PB, a partir dos quais foram levantados usos desviantes que as variedades moçambicana e brasileira apresentam em relação à europeia. Para tanto, o presente capítulo está organizado da seguinte forma: em 2.1, apresenta-se a estrutura argumental dos verbos de movimento no português, uma vez que seu entendimento é importante para a compreensão das possíveis funções que os PPs locativos podem desempenhar nesse tipo de predicado; na seção 2.2, expõe-se a maneira com que PPs locativos são licenciados e organizados na estrutura sintática; e, na seção 2.3 , trata-se da função da preposição no processo de licenciamento dos locativos.

\subsection{Estrutura argumental dos verbos de movimento}

Tradicionalmente entendidos como predicados intransitivos (cf. Almeida, 1978; Cunha \& Cintra, 1985), os verbos que denotam movimento direcional, como "ir", "vir", "voltar", "chegar", entre outros, sempre foram objeto de discussão no que se refere a sua estrutura argumental. Considerando-se que a organização da estrutura argumental pressupõe a noção de predicação, que consiste nas relações sintático-semânticas que se estabelecem entre um núcleo lexical (Nome, Verbo, Adjetivo, Preposição ou Advérbio) e seus argumentos, importa definir, primeiramente, os critérios para a diferenciação entre o que na literatura se denomina argumento e adjunto.

Um desses critérios inclui considerar que adjuntos participam do predicado verbal, sem, no entanto, depender de um item lexical específico, conforme exposto em Mateus et. al. (2003). Nessa perspectiva de análise, adjuntos são facultativos na construção de sentenças, distinguindo-se, por isso, dos argumentos. Seguem-se alguns dos exemplos dados pelas autoras para esclarecer tal diferenciação: 
(1) a. Os atletas partiram [para Estocolmo] ontem à noite.

b. Vi [muitos quadros de Monet] no Museu Marmotan.

Nessas sentenças, os sintagmas entre colchetes correspondem aos argumentos selecionados pelos verbos "partir" e "ver", para os quais, respectivamente, não há previsão da informação de tempo nem de espaço apresentada em negrito. Nessa perspectiva, os sintagmas em negrito são classificados como adjuntos, e os delimitados nos colchetes são argumentos.

Com relação à quantidade de argumentos que um verbo pode selecionar, Mateus et al. (2003, p. 185) distinguem quatro tipos de predicadores verbais:

I. verbos com zero argumentos: Hoje amanheceu às 5 horas.

II. verbos com um argumento: [Maria] gritou, porque teve um pesadelo. / [O menino] nasceu à noite.

III. verbos com dois argumentos: [O Boavista] venceu [o campeonato] em 2001.

IV. verbos com três argumentos: [Pedro] emprestou [seu livro de matemática] [ao João].

Mateus et al. (2003) explicam que esses enquadramentos são relevantes ao estudo da sintaxe dos verbos à medida que, ao justificarem as propriedades semântico-lexicais desses itens, destacam a permanente interação entre sintaxe e semântica estabelecida nas operações gramaticais, uma vez que propriedades semânticas dos itens lexicais também são relevantes para que uma sentença convirja ou não.

Além da quantidade, os argumentos são selecionados conforme sua natureza categorial, sendo esse outro critério importante para a construção da estrutura argumental dos verbos, segundo Mateus et. al. (2003). Isso significa dizer que o predicador verbal exige categorias sintáticas específicas em sua estrutura argumental. Por exemplo: o verbo “acreditar" prescinde um sintagma preposicional (PP) como argumento interno; por sua vez, o verbo "aborrecer" exige um sintagma nominal/determinante (NP/DP). Caso essas condições sejam violadas, será gerada uma sentença com padrão não previsto na língua portuguesa, o que acarretará a agramaticalidade da sentença.

O terceiro e último critério levantado por Mateus et. al. (2003) na definição dos componentes da estrutura argumental dos verbos refere-se aos chamados papéis temáticos. 
Adotando os pressupostos de P\&P (Chomsky, 1986), as autoras argumentam que os verbos atribuem papel temático a cada argumento que selecionam, ou seja, indicam o tipo de relação semântica que estabelecem com seus argumentos. Os papéis temáticos elencados por Mateus et al. (2003) estão sistematizados nos tópicos a seguir, com a ressalva de que se trata de um recorte no âmbito de várias teorias (cf. Cançado, 2009):

- Agente: entidade controladora, tipicamente humana;

- Tema: entidade que muda de lugar, de posse ou de estado, podendo ter sido criada pela atividade expressa pelo verbo ou afetada por ela;

- Fonte: faz parte da origem de uma situação, mas não pode controlá-la. Geralmente, a entidade com esse papel temático está ligada a uma força da natureza, um lugar ou um ser animado que desencadeia uma mudança de forma não intencional;

- Locativo: exprime a localização espacial de uma entidade;

- Alvo: representa o receptor, animado ou locativo, para o qual algo foi transferido; ou seja, ocorre em uma situação de transferência.

Assim como a noção de categoria, o papel temático do argumento selecionado pelo verbo acarreta consequências para a construção sintática, conforme exemplificam Mateus et al. (2003, p. 187):

(2) a. $[\mathrm{O} \text { criminoso }]_{\mathrm{SN}}$ assassinou [três motoristas $]_{\mathrm{SN}}$

a'. $*[\text { A tempestade }]_{\mathrm{SN}}$ assassinou [três motoristas $]_{\mathrm{SN}}$

b. [O João $]_{\mathrm{SN}}$ pôs [o livro $]_{\mathrm{SN}}[\text { na estante }]_{\mathrm{SP}}$ b'. *[O João $]_{S N}$ pôs $[0 \text { livro }]_{S N}[\text { para a estante }]_{S P}$

Observa-se que a troca dos papéis temáticos de agente para fonte, no primeiro par, e de locativo para alvo, no segundo par, resultou sentenças agramaticais, ainda que a categoria dos argumentos estivesse satisfazendo as condições de seleção categorial exigidas pelos verbos.

Acerca especificamente dos VPs projetados por verbos de movimento, Mateus et. al. discorrem o seguinte: 
(...) há verbos que não asseguram sozinhos a marcação temática dos seus argumentos internos. Constatam-se entre eles os verbos não causativos de movimento, de que são exemplos irl vir, entrarl sair, partirl chegar. Tratando-se de verbos não estativos de movimento, a sua natureza lexical associa-os à ideia de mudança de lugar. Contudo, os papéis temáticos de Fonte, Alvo ou Locativo só são atribuídos pela combinação do verbo com uma preposição específica: de, para Fonte, em, para o Locativo, a ou para, para o Alvo. (MATEUS et al., 2003, p. 202)

Desse excerto, infere-se que as autoras assumem, com base nos pressupostos de $\mathrm{P} \& \mathrm{P}$, que os verbos de movimento atuam em conjunto com as preposições na atribuição do papel temático ao argumento locativo, o que significa dizer que é obrigatória, no PE, a inserção de preposição introduzindo o argumento locativo desse tipo de verbo. Aproveitando as propriedades de seleção argumental até aqui descritas, interessa-nos delinear, com maior precisão, as propriedades específicas de seleção argumental de verbos de movimento. Para tanto, assumimos a aplicação da Hipótese Inacusativa nesses contextos verbais, como proposto por Levin \& Rappaport (1992) e Duarte \& Brito (2003).

A Hipótese Inacusativa foi inicialmente formulada por Perlmutter (1978) e posteriormente refinada por Burzio (1986). Essa hipótese consiste na identificação de duas classes de verbos intransitivos: uma em que os verbos selecionam um argumento interno, ao qual é atribuído o papel temático de Tema; e outra em que os verbos selecionam um argumento externo, ao qual é atribuído o papel temático de Agente. Uma consequência dessa distinção é que os verbos intransitivos que selecionam o argumento interno não têm propriedades licenciadoras do Caso acusativo. Essa restrição dá origem à generalização de Burzio, segundo a qual um verbo incapaz de atribuir Caso acusativo também é incapaz de atribuir papel temático compatível com argumento externo. Assim, devido à impossibilidade de marcação de Caso acusativo, esses verbos são denominados inacusativos.

No modelo de Regência e Ligação (Chomsky, 1981), postulava-se que os Casos eram atribuídos por categorias predicadoras, entre as quais se incluem os Verbos e as Preposições. Em construções inacusativas, como o argumento interno não consegue receber Caso na posição em que foi gerado, ele deve se mover para a única posição de Caso disponível, que seria a Spec-IP, responsável pelo estabelecimento da atribuição de Nominativo ao DP que desencadeia concordância com o verbo, movido para I com a finalidade de realizar flexão. A seguinte representação arbórea demonstra a concepção de estrutura inacusativa no modelo de Regência e Ligação: 


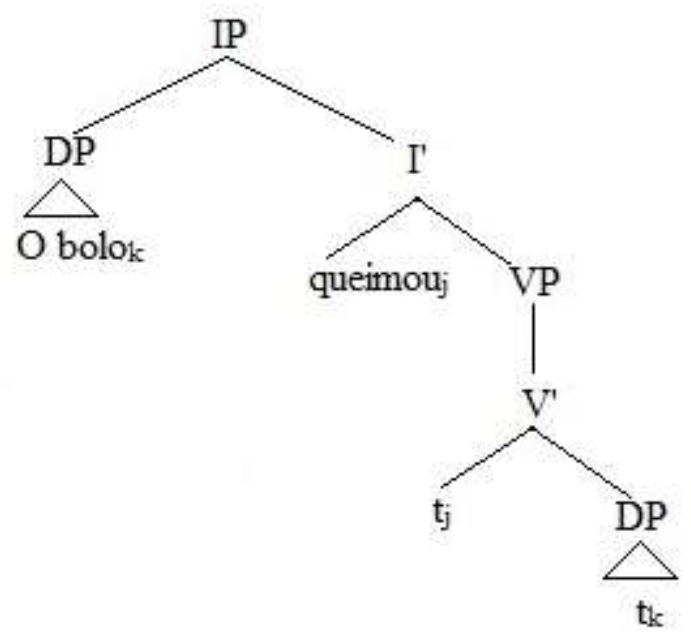

Nessa análise, assume-se que o especificador de VP não é projetado, e o argumento que funciona como sujeito é, na verdade, o argumento interno que foi demovido para uma posição em que pudesse receber Caso, isto é, para Spec-IP. Assim, o Nominativo é atribuído ao argumento interno, haja vista ser esse o único Caso disponível na estrutura.

Em termos minimalistas, o contraste entre inergativos e inacusativos é estabelecido em função da projeção do núcleo funcional v', o qual, conforme mencionado anteriormente (capítulo 1, seção, 1.2), é responsável por abrigar o argumento com papel temático externo. Nos casos dos predicados inacusativos, não ocorre a projeção de $v \mathrm{P}$, já que não há argumento externo para o qual $v$ ' possa atribuir papel temático externo. Por esse motivo, $v \mathrm{P}$ não participa da projeção sintática de predicados inacusativos. O que ocorre nas construções inacusativas, de acordo com a abordagem minimalista, é que a presença do traço EPP em T implica a movimentação do argumento interno para Spec-TP, posição em que esse sintagma valora os traços de Caso Nominativo via Agree, o que é essencial para que a sentença seja gramatical, uma vez que esse traço tem de ser valorado antes de Spell-out.

Inicialmente, propôs-se que os verbos “ir", "chegar", "voltar”, entre outros verbos de movimento, incluíam-se no grupo dos verbos inacusativos, uma vez que o sujeito desses verbos não comportava papel temático de Agente, mas de Tema, e cumpriam, em certa medida, os testes diagnósticos de inacusatividade. Ao encontro dessa argumentação, Levin \& Rappaport (1992), e posteriormente Duarte \& Brito (2003) empreenderam uma discussão, para os dados do português, relativa ao estatuto argumental do sintagma locativo selecionado por esses verbos, uma vez que as evidências demostravam que não se tratava de mero adjunto, sendo, por vezes, indispensável para a gramaticalidade da sentença. Nesse sentido, entende-se 
que o argumento locativo satura as relações argumentais e temáticas dos verbos de movimento, devendo, por isso, ser incluído na estrutura. No entanto, como dar conta de verbos inacusativos que selecionam dois argumentos?

Entre outros pesquisadores, Tortora $(1996 ; 1997)$ levantou a hipótese de que os verbos de movimento direcional constituem uma classe específica de verbos inacusativos: os inacusativos biargumentais. Esses verbos selecionam um argumento interno DP, posteriormente alçado à posição de sujeito (Spec-TP), e um argumento oblíquo, PP, com papel temático Locativo. A depender do contexto, este último pode ser dispensável ou indispensável para a gramaticalidade da sentença.

A fim de melhor compreender a estruturação de um PP locativo no âmbito da estrutura argumental de um VP projetado por um verbo de movimento, sob a hipótese de ser esse inacusativo biargumental, é necessário entender como a literatura analisa os próprios PPs locativos. Para tanto, a seção seguinte apresenta, então, as descrições que a literatura fornece para explicar o licenciamento dos PPs locativos no português.

\subsection{Distribuição e licenciamento dos sintagmas locativos}

A fim de demonstrar sob quais condições os PPs locativos comportam-se como argumentos e adjuntos, para depois empreender a discussão acerca do licenciamento dos PPs locativos em predicados com verbos de movimento, partimos da assunção de que sintagmas preposicionados podem funcionar como oblíquos obrigatórios (4), opcionais (5) ou adjuntos (6), conforme demonstrado em Mateus et. al. (2003, p. 294):

(4) a. João pôs o livro [na estante].

b. O cobrador foi [ali].

(5) a. O Pedro viajou [do México] [para Lisboa].

b. O João trouxe [do Senegal] essa estatueta.

(6) a. O meu amigo pintou um quadro [para Maria].

b. Há falta de leite [por causa da seca].

Além das sentenças, as autoras apresentam o teste interrogativo "O que é que [sujeito] fez [oblíquo]?” para definir a diferença entre os oblíquos obrigatórios e os adjuntos: 
(7) a. P: "O que é que meu amigo fez [para Maria]?”

R: "Pintou esse quadro."

b. P: *O que é que João fez [na estante]?

R: "Pôs o livro."

Pelo teste, demonstra-se que, ao contrário dos oblíquos adjuntos, os oblíquos obrigatórios ligam-se diretamente ao verbo, sendo, pois, parte de sua grelha e projeção argumentais.

À luz da proposta de Larson (1988) para verbos bitransitivos ${ }^{11}$, assumimos a hipótese de que os argumentos de verbos inacusativos biargumentais são projetados no domínio mínimo de V. Sendo os verbos de movimento inacusativos biargumentais, conforme a hipótese adotada neste estudo, propomos ${ }^{12}$ que o argumento Tema e o argumento Locativo selecionados por verbos de movimento são projetados, respectivamente, na posição de especificador e complemento de V. Assim, para uma sentença como "A Maria saiu de casa", sugerimos a seguinte representação arbórea, na qual assumimos que o verbo "sair" é um inacusativo biargumental:

(8)

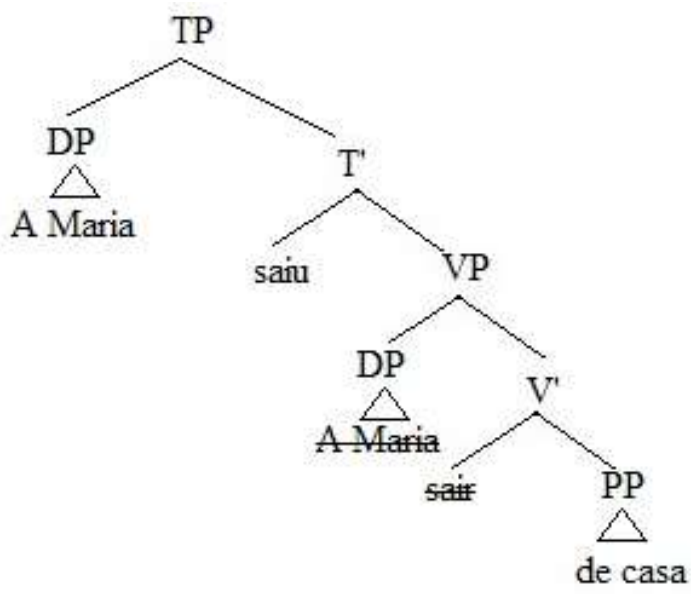

\footnotetext{
${ }^{11}$ Na proposta de Larson (1988), uma sentença como "João entregou o livro a Ana” possui a seguinte projeção: o argumento Alvo [a Ana] é licenciado como complemento de V, posição em que terá seu Caso atribuído pela preposição que projeta o PP; o argumento Tema [o livro] é licenciado em Spec-VP; e o argumento externo é licenciado em Spec- $v \mathrm{P}$.

${ }^{12}$ Essa hipótese é igualmente adotada por Munhoz (2011) na discussão das estruturas de tópico-sujeito locativo, como será apresentado na seção 3.3 do capítulo 3 deste estudo. A autora baseou-se na proposta de Lunguinho (2005 apud Munhoz, 2011) referente à projeção dos argumentos nas construções de tópico-sujeito genitivo.
} 
Considerando que a posição temática de argumento externo é Spec- $v \mathrm{P}$, a qual não está disponível nas construções inacusativas, e que Spec-VP é a posição temática de argumento interno, assumimos ser coerente adotar a proposta de que o DP [A Maria] é inserido na estrutura em Spec-VP, uma vez que esse sintagma se comporta, de fato, como um argumento interno. Sendo T rico em traços- $\phi$ e em EPP, esse sintagma move-se para Spec-TP para valorar esses traços via Agree. A respeito da projeção do PP locativo interno ao VP, evidencia-se que, diferentemente de um PP adjunto, que possui caráter opcional na sentença (isto é, sua exclusão não prejudica a gramaticalidade da sentença), o PP locativo é obrigatório para a gramaticalidade do predicado com verbo de movimento. É possível sua omissão, porém isso implica uma leitura dêitica do local do evento. Ou seja, esse PP tem de estar projetado na estrutura, mesmo que seu núcleo seja ocupado por uma categoria vazia, a qual será, nesse caso, responsável pela interpretação dêitica do locativo.

Tomando-se uma sentença como “A Maria saiu de casa por causa do calor”, exposta originalmente em Mateus et. al. (2003, p. 416), pode-se entender alguns dos fatores que diferenciam um locativo adjunto de um locativo argumental. Um desses fatores corresponde à mobilidade do sintagma na sentença, como apresentamos a seguir:

(9) a. Por causa do calor, a Maria saiu de casa.

b. A Maria, por causa do calor, saiu de casa.

c. A Maria saiu, por causa do calor, de casa.

(10) a. *A Maria de casa saiu por causa do calor.

b. De casa, a Maria saiu por causa do calor.

É possível notar que o PP adjunto (“por causa do calor") possui maior mobilidade que o PP argumento (“de casa”), uma vez que, por (9a-c), constata-se que aquele sintagma possui maior liberdade de movimentação na sentença. Ao contrário, o PP argumento necessita estar em uma posição mais próxima do verbo, senão a sentença pode até se tornar agramatical, como em (10a). Em outros casos, o licenciamento do PP locativo em outras posições está condicionado à projeção de uma categoria no domínio de CP, ou seja, no domínio discursivo, como em (10b). Isso significa que a movimentação do PP argumento deve ser sintaticamente motivada, ao passo que a do PP adjunto não. 
Além das diferentes posições que o oblíquo obrigatório e o oblíquo adjunto ocupam na estrutura, diferencia-os a preposição que os introduz, no que se refere ao estatuto funcional ou lexical que assume em cada contexto sintático, conforme postulado por Chomsky (1986).

Sendo a diferenciação desses estatutos um dos pontos mais importantes da presente pesquisa, dedicamos a seção seguinte para tratar especificamente da preposição nos sintagmas locativos.

\subsection{O papel das preposições no licenciamento dos sintagmas locativos em estruturas com verbos de movimento}

Há muito os estudos linguísticos vêm verificando que as preposições constituem uma categoria híbrida, de comportamento sintático heterogêneo, uma vez que ora se comportam como categorias lexicais, ora como gramaticais. Tais classificações remontam à tradição gramatical greco-latina, segundo a qual as palavras que se enquadram no conjunto das categorias lexicais apresentam maior aporte semântico que às das categorias funcionais/gramaticais. No entanto, nos estudos tradicionais prevaleceu o entendimento de que preposições são categorias relacionais, enquanto a distinção entre preposições lexicais e funcionais adquire um significado teórico no âmbito da Teoria Gerativa somente a partir de Chomsky $(1981,1986)$.

O comportamento das preposições no português relaciona-se às origens da língua, especificamente na passagem do latim vulgar para o português arcaico, de acordo com Tarallo (1990). Segundo o autor, as transformações do latim ao longo dos séculos desencadearam reduções tanto no quadro de declinações morfológicas quanto no número de casos atribuídos morfologicamente (de seis, reduziu-se a dois). Tais reduções decorreram de um processo fonológico de neutralização dos segmentos finais das palavras, os quais indicavam sua declinação e seu caso - inversamente, admite-se a possibilidade de que mudanças na constituição formal das categorias (funcionais) podem ter tornado obsoletos tais segmentos, conduzindo à neutralização e à eliminação dos mesmos.

Diante da neutralização dos casos morfológicos, surge, entre as novas estratégias de licenciamento das categorias argumentais antes explicitadas pelas desinências, o sistema de preposições. Tarallo (1990) ressalta que a quantidade de preposições latinas era muita pequena para suplantar todas as desinências de caso anteriormente existentes, por isso o pequeno conjunto de preposições disponível foi sendo empregado em diferentes contextos. 
Van Hoecke (1996) afirma que a proximidade nocional entre Dativo e Locativo pode ter sido um dos fatores que implicaram o compartilhamento da preposição latina $a d$ (equivalente à portuguesa "a") como marcadora desses dois tipos de Caso. Inicialmente empregada apenas para marcar Locativo (11a), diferenciando-se o Dativo pela desinência casual (11b), a preposição ad foi aos poucos sendo igualmente empregada em contextos locativos e dativos (11c-11e), a ponto de não mais marcar uma diferenciação morfológica entre esses Casos, conforme apresentado nos dados subsequentes:

\author{
(11) a. Adducere exercitum [ad urbem] \\ conduzir exército-AC [a cidade-AC] \\ "Conduzir o exército à cidade"
}

(VAN HOECKE, 1996, p. 20)

\title{
b. Caesar regnum [Cleopatrae] dedit \\ César reino-AC [Cleópatra-DAT] dar
}

"César deu o reino a Cleópatra"

(VAN HOECKE, 1996, p. 6)

$$
\begin{array}{lll}
\text { c. Hunc } & {\left[\begin{array}{ll}
\text { ad } & \text { carnificem }
\end{array}\right]} & \text { dabo } \\
\text { esse-AC }\left[\begin{array}{ll}
\text { a } & \text { carrasco-AC }
\end{array}\right] & \text { entregarei }
\end{array}
$$

"Entregarei esse (homem) ao carrasco"

d. [Ad hostes $]$ exuvias dabit

a inimigos-AC peles-AC deixarei

"Deixarei as peles para os inimigos"

(VAN HOECKE, 1996, p. 21)
e. Puer adnatat ${ }^{8}$
[delphino]
criança aproximou nadando golfinho-DAT

\begin{abstract}
8 Importa ressaltar que as preposições latinas têm uma estreita relação com os advérbios, como esclarece Said Ali: "Há pontos de contacto entre os advérbios e as preposições, e sabe-se que as preposições latinas foram primitivamente advérbios." (SAID ALI, 2001, p. 154). Em virtude disso, encontra-se a forma ad na estrutura morfológica do verbo - natat, como em (11e), a qual ocorre posteriormente como preposição introdutora de um sintagma em adjunção ao predicado.
\end{abstract}


"A criança nadou para/até o golfinho."

(VAN HOECKE, 1996, p. 10)

Para Van Hoecke, a maior transparência semântica das preposições para a indicação de direcionalidade/trajetória resultou na expansão do seu uso para outros contextos casuais que não o de Locativo: "(...) the fundamental characteristic of the dative seems to be to indicate the pole towards which the process expressed by the predicate is directed. Occasionally, the dative takes on the behaviour of a real locative of destination (...)" (VAN HOECKE, 1996, p. 11) ${ }^{13}$.

No desenvolvimento inicial da teoria de categorias sintáticas, Chomsky (1965) assume que as categorias lexicais são definidas de acordo com traços categoriais binários baseados nas propriedades dos Nomes e dos Verbos, a saber [+/-N] e [+/-V], cuja combinação permite quatro possibilidades lógicas, que, por hipótese são associadas às categorias lexicais, a saber: $\mathrm{N}=[+\mathrm{N},-\mathrm{V}], \mathrm{V}=[-\mathrm{N},+\mathrm{V}], \mathrm{A}=[+\mathrm{N},+\mathrm{V}]$. Nessa época, Chomsky não cogitava a possibilidade de as preposições serem alinhadas com as categorias lexicais, predicadoras. Somente a partir de 1981, as preposições passam a ser consideradas categorias lexicais portadoras dos traços $[-\mathrm{N} ;-\mathrm{V}]$.

Ainda assim, somente em 1986, Chomsky postula que as preposições demonstram particularidades que as demais categorias lexicais não possuem, como o fato de serem acionadas na estrutura sintática por um requisito que nada tem a ver com o papel de predicador, próprio dos núcleos lexicais, ao atuar no licenciamento de Caso de complementos de adjetivos (12a) ou de substantivos (12b), por exemplo:

(12) a. John is proud *(of) his children.

b. the destruction *(of) the city

(ROBERTS, 1997, p. 87 - 88)

Por hipótese, tanto o adjetivo "proud" quanto o substantivo "destruction" estão impossibilitados de atribuir Caso diretamente aos seus argumentos, porque apresentam traço

\footnotetext{
13 “a característica fundamental do dativo parece ser indicar o polo de orientação para o qual o processo expresso pelo predicado está direcionado. Ocasionalmente, o dativo adquire um comportamento de um verdadeiro locativo direcional" (tradução nossa).
} 
$[+\mathrm{N}]^{14}$. Por isso, a preposição, que apresenta o traço $[-\mathrm{N}]$, é inserida entre predicador e argumento, a fim de intermediar a atribuição de Caso, o que a caracteriza como uma categoria funcional. Sem a manifestação da preposição, a sentença seria agramatical.

Observando que as preposições assumem estatutos distintos a depender da estrutura argumental em que estejam inseridas, Chomsky (1986) estabelece uma diferenciação entre preposições que têm comportamento funcional ou lexical. Nesse sentido, a preposição funcional distingue-se dos casos em que ocorre como predicador, ou seja, como categoria lexical, em que seleciona argumentos, definindo, portanto, uma estrutura argumental. A seguir, exemplifica-se essa diferença com dados do PB:

(13) a. Maria trabalha com luvas.

b. Pedro está orgulhoso de seus filhos.

Em (13a), a preposição “com” tanto marca o papel temático (instrumento) quanto atribui Caso oblíquo ao DP [luvas], não requerido pelo predicador verbal da sentença, "trabalha". Nesse contexto, diz-se que a preposição é lexical, ou verdadeira (cf. Salles, 1992), uma vez que se comporta como um típico item predicador. Já a preposição “de” (13b) apenas marca o Caso (estrutural), enquanto o adjetivo "orgulhoso" atribui o papel temático ao DP [seus filhos]. A tradição gerativa também denomina as preposições funcionais de preposições dummy, considerando-se o baixo aporte semântico das preposições em estatuto funcional.

Salles (1992) propõe, ainda, que há contextos em que as preposições apresentam estatuto lexical e realizam o papel temático juntamente ao item lexical predicador, como apresentado em (13c) abaixo:

(13) c. confia em seu amigo / concorda com a ideia / acredita em deus

Com isso, as preposições funcionais comportam-se de uma única maneira realizando Caso atribuído por outro item lexical (como em 13b) —, ao passo que as preposições lexicais ou atribuem Caso e papel temático ao elemento que selecionam (13a), ou atribuem Caso e realizam papel temático ao item selecionado por um predicador verbal (como

\footnotetext{
${ }^{14}$ Roberts (1997, p. 88 - 89) ressalta que, diante da evidência de dados do alemão em que adjetivos atribuem sozinhos Caso a seus complementos, é possível que, em algumas línguas, Caso inerente seja licenciado sem a ativação de uma marca morfossintática, o que não é comportado na gramática do inglês.
} 
em 13c). Salles (1992) ressalta, ainda, que uma diferença fundamental entre o estatuto funcional e o lexical diz respeito à possibilidade de apagamento da preposição em determinadas condições. Enquanto as preposições lexicais ("sem”, “até”, “desde", "entre”, "sobre" etc.) são sempre obrigatórias na estrutura, as preposições funcionais admitem opcionalidade quando introduzem complemento de natureza oracional, por exemplo:

(14) Maria gosta (de) que lhe deem chocolates.

Com base nessas considerações, cabe indagar qual é o estatuto da preposição nos predicados com verbos de movimento. Por um lado, verificamos que o PP locativo pode ser omitido, como em Os alunos saíram (para o pátio). No entanto, tomando-se os verbos de movimento como uma classe, constata-se que a escolha da preposição que introduz o PP locativo determina o significado da predicação, o que torna o PP obrigatório, como no caso do verbo “vir” (Veio de/para São Paulo).

Nesse sentido, assumimos que é adequado o tratamento dado a esses verbos como inacusativos biargumentais, considerando que o PP locativo é um argumento interno do predicado que pode ser omitido em favor de uma interpretação não marcada, como em $M e u$ amigo veio (da escola para minha casa), em que é assumida a leitura de um movimento de um ponto de origem para um ponto que toma como referência o locutor.

Portanto, levando-se em consideração o tipo de predicador da sentença, o PP locativo pode ser projetado em posição adjunta, se estiver introduzindo um sintagma que não compõe a estrutura argumental do verbo, ou é projetado internamente ao VP, se o sintagma locativo for previsto na estrutura argumental do predicador, como no caso dos verbos de movimento, para os quais assumimos a classificação de inacusativos biargumentais, conforme referido na seção anterior deste capítulo. 


\section{CAPÍTULO 3}

\section{ASPECTOS SINTÁTICOS E SEMÂNTICOS DOS SINTAGMAS LOCATIVOS NO PORTUGUÊS DE MOÇAMBIQUE: UMA ANÁLISE COMPARATIVA COM DADOS DO PORTUGUÊS DO BRASIL}

Este capítulo é dedicado à análise dos dados do PM recolhidos do corpus de Gonçalves (1990). O objetivo é verificar o papel das preposições na expressão sintática dos fenômenos relacionados aos sintagmas locativos nessa língua. Para tanto, promove-se uma articulação entre as análises das evidências empíricas e o tratamento que a Teoria Gerativa vem conferindo aos argumentos locativos não só do PM, mas também de diferentes línguas. Além de assumir alguns argumentos presentes na literatura, levantamos novas propostas de análise com base nos modelos tomados como referência.

O capítulo organiza-se da seguinte forma: na seção 3.1., são apresentados os dados relativos ao comportamento das preposições que compõem argumentos locativos em função oblíqua. Nessa seção, são empreendidas discussões com base na literatura que trata ou especificamente desse assunto, ou de fenômenos que se aproximam dos encontrados no PM, buscando-se construir uma análise que respeite os pressupostos de adequação explanatória e explicativa da Teoria Gerativa; na seção 3.2., apresentamos a proposta de representação sintática da estrutura interna de PPs locativos, com base em Tortora (2008), estabelecendo suas implicações para a diferenciação na expressão do PP locativo no PM, no PB e no PE; na seção 3.3, comparamos as construções de tópico-sujeito e de inversão locativa do PB às construções do PM que apresentam um PP locativo pré-verbal, com a finalidade de averiguar se os dados do PM constituem exemplos dessas construções. Essa seção contém ainda a subseção 3.3.1, na qual analisamos as construções do PM em que o PP locativo pré-verbal ocorre em predicados com cópula. Nessa seção, concluímos que os dados PM analisados não configuram as construções de tópico-sujeito encontradas no PB, mas alguns deles podem ser analisados como um tipo de inversão locativa.

\subsection{PPs locativos em predicados com verbos de movimento}

Com relação à realização dos PPs locativos como argumentos oblíquos de verbos de movimento direcional no PM, os dados de Gonçalves (1990) revelam que essa língua não segue necessariamente os mesmos padrões de marcação do PE, como se observa nos dados a 
seguir, principalmente no que se refere à seleção da preposição introdutora do PP locativo, uma vez que o PE prevê, para esses predicados, a preposição "a" ou "para":

(1) a. "vem matinê dançante [no Zambi]"

b. "o Januário que era o adjunto do comandante foi portanto [num combate]"

c. "nem todos íamos [na mesma escola]"

d. "e fomos [nas casas de banho] para poder lavar a cara um bocado"

e. "voltar por acaso vivo [em casa]"

f. "saímos [no centro] onde estivemos todos"

g. "nós fomos os primeiros a chegar [na ilha da juventude]"

Nota-se que, independentemente do verbo de movimento, a preposição "em" é selecionada para introduzir o sintagma locativo, inclusive quando este é argumento de um verbo como "sair", para cuja estrutura argumental se prevê, no PE, a realização de locativo introduzido ou pela preposição "de", denotadora de origem, ou pela preposição "para", denotadora de destino, como observam Gonçalves \& Chimbutane (2004). Os autores afirmam que há uma tendência de uso da preposição "em" na construção de sintagmas locativos que indicam "lugar onde" ", de modo que essa estratégia generalizante de marcação do locativo é a mais utilizada pelos falantes do PM.

Em sua análise acerca desse assunto, Gonçalves \& Chimbutane (2004) argumentam que, no PM, a preposição "em" não possui valor lexical, mas apenas funcional. Segundo os autores, no processo de aquisição/construção da gramática do português em Moçambique, houve reanálise da preposição “em” com base nas propriedades das L1 (LB) dos falantes, uma vez que, nessas línguas, os locativos são expressos por morfemas (-eni / -ini / ka) que são incorporados ao Nome pelo qual se pretende designar o lugar, conforme exemplificam

\footnotetext{
${ }^{15}$ A expressão "lugar onde" foi empregada por Gonçalves e Chimbutante para explica os casos em que o PP locativo aparece na posição típica de sujeito ou objeto: "deve destacar-se em primeiro lugar o facto de que, de acordo com os dados disponíveis, apenas ocorrem na posição de sujeito e objecto directo os sintagmas em-SN que designam 'lugar onde'. Não se registram assim, por exemplo, contrapartes dos constituintes sujeito e objecto directo das frases (1b) ou (2a), como as que se seguem:

(1b)' na minha mãe era fértil (cf. (1b) na nossa zona era fértil)

(2a)' conheci nesse livro (cf. (2a) conheci em casa dela)" (GONÇALVES \& CHIMBUTANE, 2004, p. $10)$.

Em vista dos dados levantados na presente pesquisa, estendemos essa afirmação para os PPs locativos em função oblíqua.
} 
Gonçalves \& Chimbutane (2004, p. 15) com os seguintes dados ${ }^{16}$ da LB changana, uma das LB faladas em Moçambique:

(2) Tin-tombhi ti-y-e kerek-eni /ka-Gaza / ka kokwani.

10-moças 10-ir-pass 9igreja-Loc/ Loc-Gaza/ Loc 1vovó

“As moças foram na igreja/ em Gaza/ na (casa da) vovó.” (*PE; PB ${ }^{\mathrm{ok}}$ )

(3) Tin-tombhi ti-hum-a kerek-eni

10-moças MS-sair-vf 9igreja-loc

“As moças saem na igreja.” (*PE / *PB)

(4) Kerek-eni i ku-tsongo

9igreja-loc é 17-pequeno

"Na nossa igreja é pequeno." (*PE / *PB)

(5) Tin-tombhi t-a-ku-tiv-a

kerek-eni

10-moças 10MS-pres-MO-conhecer-vf

9igreja-loc

“As moças conhecem na igreja." (*PE / *PB)

A partir desses dados, Gonçalves \& Chimbutane (2004) explicam que os locativos, em LB, são expressos pela adição de morfemas específicos ao Nome que denota o locativo, podendo este ocorrer como sujeito (4) ou objeto (5) de uma oração, uma vez que pertence à categoria N. Ou seja, nessas línguas, a marcação do locativo não se restringe à função oblíqua, ao contrário do que ocorre no PE. Os autores acrescentam que, nas LB, a expressão de "direção" é incorporada no verbo de movimento, de maneira que a informação temática de "meta/destino" ou "origem" é inerente ao verbo.

Fundamentando-se em Talmy (1985), Gonçalves \& Chimbutane (2004) analisam as LB como parte de um grupo de línguas do tipo verb-framing, nas quais o movimento é lexicalizado pelo predicador verbal. Nesse modelo, o PE enquadra-se no grupo das línguas

\footnotetext{
${ }^{16}$ Abreviaturas adotadas nas glosas por Gonçalves e Chimbutane (2004), mas não neste estudo: pass = tempo passado; $\mathrm{MS}=$ marca de sujeito; vf = morfema que manifesta a propriedade verb-framing; pres = tempo presente; $\mathrm{MO}=$ marca de objeto.
} 
satellite-framing, nas quais a informação de "origem" e "direção" do movimento é expressa mediante o apoio de elementos morfossintáticos - as preposições. ${ }^{17}$

Tendo como base o padrão verb-framing e a marcação morfológica de locativo das LB, os falantes do PM teriam passado a priorizar a lexicalização do movimento em detrimento da realização das preposições direcionais, como defendem Gonçalves \& Chimbutane (2004). Para os autores, outra configuração do sintagma locativo no PM associada à propriedade verb-framing diz respeito à possibilidade de ausência de preposição introdutora desse sintagma, de maneira a ser o argumento locativo expresso por um NP/DP:

(6) a. "saiu [regulamento] um despacho"

b. "até chegávamos [um certo ponto] de vivermos assim tímidos"

(Gonçalves, 1990, p. 398 e 466)

c. "não posso entrar [o lugar] que tem muitas mulheres."

(Gonçalves \& Chimbutane, 2004, p. 9)

Apesar de tais dados, entendemos que a defesa de que a propriedade verb-framing presente em LB leva o falante do PM a dispensar as preposições do português parece não ser argumento suficiente para justificar o apagamento das preposições, uma vez que os próprios autores registram que esse apagamento é menos frequente, representando apenas cerca de $6 \%$ dos dados analisados. ${ }^{18}$

Além disso, o recurso à preposição "em" como introdutora de locativos não é uma estratégia exclusiva, ainda que majoritária. Por outros dados de Gonçalves (1990), atesta-se uma larga realização de locativos introduzidos por "para" em predicados com verbos de movimento:

(7) a. "fui [para a cidade capital de Inhambe]"

b. "foi-se embora [para casa]"

c. "caso era necessário vinha [para cá] consultar como devia fazer os problemas"

d. "então saí [para a beira] (...) de lá vim [para cá]"

\footnotetext{
${ }^{17}$ Ainda que haja essa divisão entre línguas verb-framing e satellite-framing, Gonçalves e Chimbutane (2004, p. 22) atentam para a possibilidade de existência de padrões alternativos dentro de uma língua, como ocorre em inglês: The boy moved across the road. / The boy crossed the road. Essa observação se aplica ao português, com dados semelhantes: $O$ menino se deslocou através do parque/ $O$ menino atravessou o parque.

${ }^{18}$ Gonçalves e Chimbutane (2004, p. 10) apresentam uma tabela em que consta, entre outros fatores, o quantitativo de locativos realizados como DPs (SNs, na referida tabela). Das 80 frases analisadas, registraram-se apenas 5 ocorrências desse tipo.
} 

e. "só voltei [para aqui] o ano passado"
f. "quando curou não voltou mais [para Moçambique]"
g. "e tornou a regressar [para a casa do meu pai]"

Observa-se que, à exceção do dado (7g), os demais dados apresentam os mesmos verbos de movimento empregados em (1) e (6). Como explicar, então, a alternância observada na comparação entre os dados (1), (6) e (7)?

A partir do estudo de Farias (2006) acerca da realização intercambiável das preposições "em" e "para" como introdutoras de PP locativo na estrutura argumental de verbos de movimento direcional no $\mathrm{PB}$, elencamos alguns fatores que possam esclarecer a gramaticalidade dessas sentenças no PM, que apresenta estruturas muito semelhantes das encontradas no PB.

Com relação a dados como os apresentados em (7), Farias (2006) esclarece que, no PE, admite-se a seleção de "para" nesse contexto desde que a interpretação seja a de que o movimento realizado é [+permanente], havendo, então, uma sutil diferença entre o uso de "a" e "para" nos PPs locativos nessa língua.

Nos dados recolhidos do PM, tal condição parece se confirmar, se observados os dados em (7), especialmente (7f) e (7g). Além de não constar do corpus de Gonçalves (1990) registros de argumento locativo iniciado por "em" junto ao verbo "regressar", que, lexicalmente, prevê o traço [+permanente], o registro do verbo "voltar" com essa interpretação de movimento permanente implica, por vezes, a realização do advérbio "mais", como em (7f). Ademais, detectamos, na análise do referido corpus, que a seleção do verbo "voltar" relaciona-se prioritariamente à interpretação de movimento [-permanente], o que explicaria o uso variável da preposição "em" ou "a" nesses contextos.

Para Araújo (2008), os traços léxico-semânticos das preposições locativas atuam em seu processo de seleção nesse contexto sintático. O autor argumenta que as preposições " $\mathrm{a}$ " e "para" possuem propriedades lexicais que focalizam o percurso de um movimento [+dinâmico], ao passo que a preposição "em" destaca a interioridade e os limites do locativo, motivo pelo qual se associa, no $\mathrm{PE}$, a verbos estativos, mas não aos de movimento direcional.

Na presente análise, deduzimos que a distribuição da preposição "a" e "para" no PE, conforme descrita em Farias (2006), é opaca no input disponível para os moçambicanos, o que explica a ausência desse contraste na codificação do locativo no corpus. O que se observa 
é o uso generalizado da preposição "em" com verbos de movimento (1), em variação com a preposição "para” (7), além da situação de ausência da preposição, conforme (6).

Os casos em que ocorre a seleção da preposição "para" justificam-se, entre outros fatores, pela possibilidade de incluir uma denotação de percurso/direção. Tal explicação parece ser válida para explicar os dados em (8), extraídos de Gonçalves (1990):

(8) a. "eu nasci cá... Maputo mas fui viver [para o campo]"

b. "entrei [para a escola primária] no início de 65 "

c. "fui colocado [para a faculdade de educação]"

Ainda que nem todos os verbos apresentados acima sejam estativos, importa destacar que, no PE, a preposição "em" seria a selecionada para introduzir os PPs destacados nos colchetes.

Além de introduzir a ideia de trajetória, a preposição "para" em (8) associa-se à interpretação de movimento [+permanente] em direção a um local — concreto e distante, em (8a), e abstrato em (8b) —, embora os verbos em questão não sejam de movimento direcional.

Araújo (2008, p. 85) apresenta dados do inglês para exemplificar semelhante mudança de foco do movimento, seja em relação à trajetória ou ao ponto final:

(9) a. He walks over the bridge.

b. He lives over the bridge.

Baseando-se em Mollica (1996), Vieira (2009) ressalta que, embora relevantes, os traços semânticos das preposições por si sós não são suficientes para explicar os fatores envolvidos na formação de PPs locativos. Segundo Vieira (2009), a interação entre os traços semânticos do verbo e da preposição são fundamentais para que a sentença convirja, caso contrário, serão geradas sentenças agramaticais, conforme exemplifica a autora ${ }^{19}$ :

(10) O diretor chegou a/na/*para a repartição no horário combinado.

\footnotetext{
${ }^{19} \mathrm{O}$ estudo de Vieira (2009) analisa dados do PB. Devido à proximidade entre os dados do PB analisados por ela e os encontrados no PM, aplicamos a análise da autora considerando ser válida para os dados do PM, uma vez que a estrutura "chegar para..." não foi encontrada no corpus analisado na presente pesquisa.
} 
Nesse exemplo, por ser o aspecto semântico do verbo "chegar" focado no "ponto final" do movimento, a seleção da preposição "para" torna a sentença agramatical, uma vez que "para" é centrada no "percurso", informação não prevista nos traços léxico-conceituais de "chegar", que focaliza a "direção" e o "ponto final" do movimento. Concluímos que a observação de Vieira (2009), referente ao PB, pode ser estendida tanto ao PM quanto ao PE.

Outro fator relevante destacado por Vieira (2009) é a configuração ou grau de definitude do espaço. O locativo é composto por um Nome que representa um espaço que pode ser caracterizado como [+/-aberto]. Por exemplo, 'mercado' é um lugar [-aberto], e 'rua' é um lugar [+aberto]. Com base nisso, Vieira argumenta que um locativo [+definido] e [-aberto] tende a ser introduzido pela preposição "em", porque esta indica uma relação de interioridade. Já as preposições "a" e "para" tendem a ser selecionadas quando o locativo é [-definido] e [+aberto].

Esses traços aparentemente também se tornam opacos ${ }^{20}$ para os falantes do PM, no sentido do acesso ao input, uma vez que não se registraram tais diferenças nos locativos analisados. Considerando-se nossa hipótese de que, no PM, a preposição "em” ocorre como uma categoria funcional em contextos locativos, a referida opacidade pode ser encarada como uma condição para a reanálise desse item como uma categoria funcional, já que, conforme Roberts (1997), as preposições funcionais apresentam menor transparência semântica que as lexicais.

A hipótese acima formulada se coaduna com a proposta de Gonçalves \& Chimbutane (2004) relativa à interferência de propriedades das L1/LB dos moçambicanos no PM e ao uso generalizado da preposição “em" nessa língua, apresentada no início da discussão dos dados.

A proposta dos autores mostra-se relevante para nossa análise, na medida em que, também nesses casos, é possível estabelecer a relação entre a marcação uniforme do PP locativo pela preposição "em” e a marcação de locativos na L1/LB.

Em (11a-d), constata-se a configuração do locativo na ordem [para AdvP [em NP]] é fixa, uma vez que não se encontrou registro do inverso no corpus analisado nesta pesquisa:

(11) a. "em janeiro arrancamos para cá em Maputo."

b. "depois de dois anos posso dizer saímos para aqui em Moçambique."

c. "vim para cá no Maputo."

d. "vir de Lichinga para aqui em Maputo."

\footnotetext{
${ }^{20}$ Para maior detalhamento do conceito de opacidade, indica-se consultar Roberts (2007).
} 
Com relação a essas construções, observa-se, ainda, que a preposição "para" não é necessária para a gramaticalidade da sentença, sendo, portanto, opcional nesse contexto, haja vista os seguintes dados:

(12) a. "os dois foram ali no quartel."

b. "quase todos os domingos vinham carros lá na escola."

c. "quando eu cheguei cá no Maputo."

d. "já regressaram aqui no país."

(GONÇALVES, 1990)

É interessante notar que, embora também opcional, o advérbio locativo quase sempre está presente na construção locativa de maneira fixa.

De acordo com Jackendoff (1972), os advérbios locativos, por serem selecionados por VP, referem-se exclusivamente ao verbo ou aos argumentos por ele licenciados, o que implica menor mobilidade desses itens na sentença, principalmente quando ocorrem na presença de um PP locativo, como se verifica nos dados do PM. Por hipótese, isso ocorre devido ao aspecto lexical dêitico dos advérbios, que contribui para uma interpretação específica acerca da direcionalidade do movimento.

Na próxima seção, propomos uma análise por meio de uma estrutura articulada de PPs locativos, a fim de demonstrar como os traços formais presentes nos dados do PE (L2) são neutralizados, ou reanalisados, pelo uso uniforme da preposição "em”.

\subsection{PPs locativos como uma projeção em camadas (PP shell)}

Nesta seção, apresentamos a proposta de Tortora (2008) para a análise de preposições complexas, demonstrando que se aplica não só aos dados do PM que apresentam duas preposições locativas, como também aos dados que envolvem uma única preposição.

Em estudo acerca da realização de PPs locativos, Tortora (2008, p. 274) observa os seguintes padrões de estruturação desses sintagmas no espanhol (13) e no italiano (14):

(13) a. Juan se había escondido [bosque adentro].

b. Juan se había escondido [dentro del bosque].

"João estava escondido dentro do bosque" 
(14) a. Gianni era nascosto [dietro a 1l'albero].

b. Gianni era nascosto [dietro l'albero].

"João estava escondido dentro do bosque"

Diante da possibilidade de o PP locativo ser marcado por duas preposições (adentro, no espanhol, e dietro a no italiano) ou por apenas uma (dietro, no caso do italiano), Tortora (2008) afirma que os locativos, nessas línguas, caracterizam-se como simples, quando realizados por apenas uma preposição, ou complexos, quando realizados por duas preposições (também referida como locução prepositiva). A autora argumenta que não se trata de uma simples diferença de superfície na realização do locativo, pois fatores sintáticos e semânticos condicionam a realização de uma ou outra forma.

Entre os fatores sintáticos inclui-se a seleção da preposição. Tortora esclarece que o locativo complexo envolve uma preposição de caráter lexical (dentro / dietro) e outra de caráter funcional $(a)$. Por outro lado, o locativo simples envolve apenas a preposição lexical.

Quanto aos fatores semânticos, Tortora dispõe que PPs complexos denotam espaço "ilimitado" (unbounded), ao passo que PPs simples especificam espaço "limitado/definido entre limites/pontual" (bounded). Admitindo que PPs estão no mesmo patamar de VPs e DPs, Tortora defende que os traços semânticos supramencionados são marcados na estrutura interna do PP por meio de um núcleo funcional de aspecto (AspP).

Baseando-se no argumento de que as subcategorias conceituais PATH e PLACE especificam a categoria semântica SPACE, conforme proposto por Jackendoff (1983), Tortora postula que o PP locativo é realizado na projeção de um núcleo funcional $\mathrm{F}$, o qual é selecionado por um núcleo aspectual responsável pela especificação dessas subcategorias

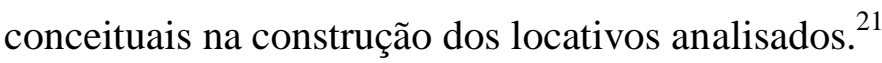

Abaixo, seguem-se as representações arbóreas propostas por Tortora (2008) para explicar o posicionamento estrutural dos PPs locativos investigados (respectivamente, o PP complexo "dietro a", do italiano, e o PP realizado pela preposição "adentro", do espanhol, em que o formativo "a-" ocorre na estrutura do item preposicional):

\footnotetext{
${ }^{21}$ Estrutura semelhante é proposta em Lobato (1995), na análise de locuções prepositivas em português, como perto de/ longe de. Em particular, a argumentação da autora é no sentido de defender que os itens perto/ longe não são preposições, mas advérbios que predicam de um DP locativo, em uma configuração de small clause, a qual, por sua vez, é selecionada pela preposição funcional de, que projeta um PP. Nessa configuração, o advérbio locativo desloca-se para o especificador do PP (funcional), e a ordem é obtida: ${ }_{\mathrm{PP}}[\mathrm{AdvP} \text { perto }]_{\mathrm{i}}\left[\mathrm{P}\right.$, de $\left[\mathrm{sc}[\mathrm{t}]_{\mathrm{i}}{ }_{\mathrm{DPP}}\right.$ casa]]. Por hipótese, na análise de Tortora (2008), o movimento para specAspP especifica/ delimita o movimento no espaço conceitual, o que requer uma elaboração teórica que não é contemplada na análise de Lobato.
} 
(15) a. "dietro all'albero"

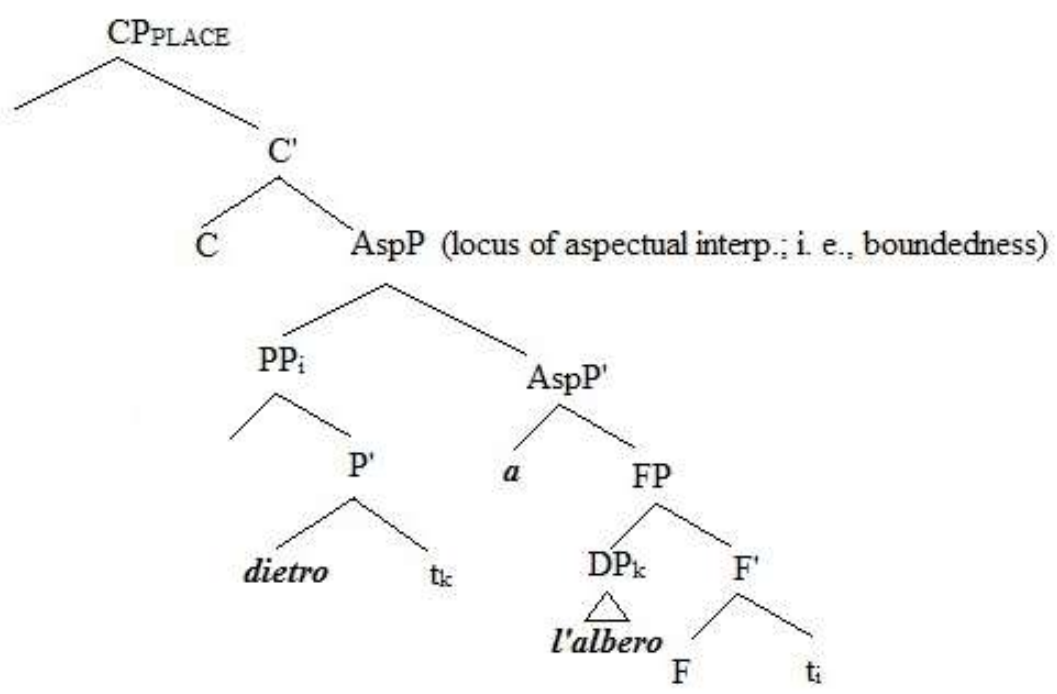

(TORTORA, 2008, p. 284)

b. "monte adentro"

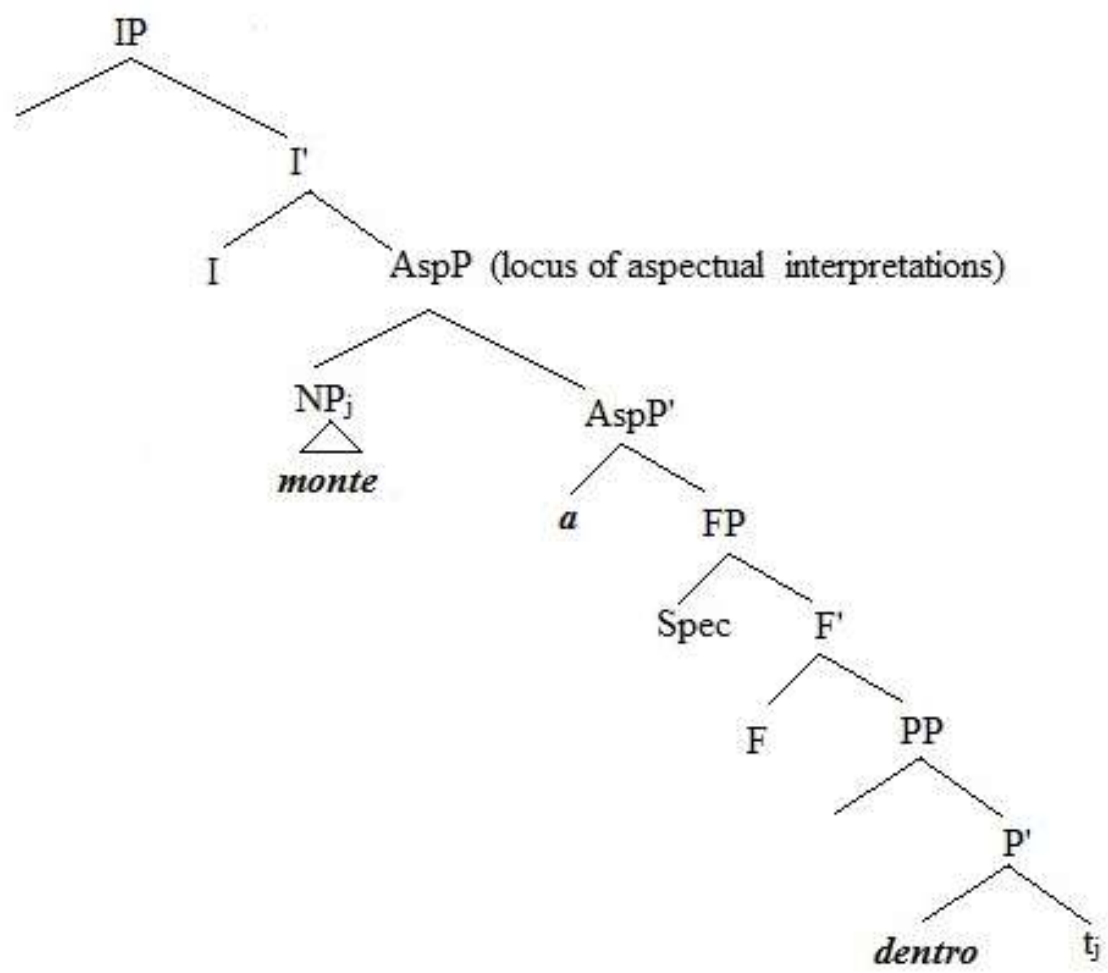

(TORTORA, 2008, p. 289) 
Tomando como referência o modelo de análise proposto por Tortora para locativos complexos, sugerimos que os dados em (11), repetidos aqui em (16), podem ser analisados da seguinte forma: a preposição "em” ocupa o núcleo da projeção AspP e apresenta estatuto funcional, exercendo papel de marcadora de Caso, ao passo que a preposição "para", de estatuto lexical, projeta PP, mas posteriormente se move, juntamente com seu complemento, para Spec-AspP, conforme a representação arbórea apresentada em (17), igualmente válida para todas as construções em (16):

(16) a. “em janeiro arrancamos para cá em Maputo.”

b. "depois de dois anos posso dizer saímos para aqui em Moçambique."

c. "vim para cá no Maputo."

d. "vir de Lichinga para aqui em Maputo."

$(17)$

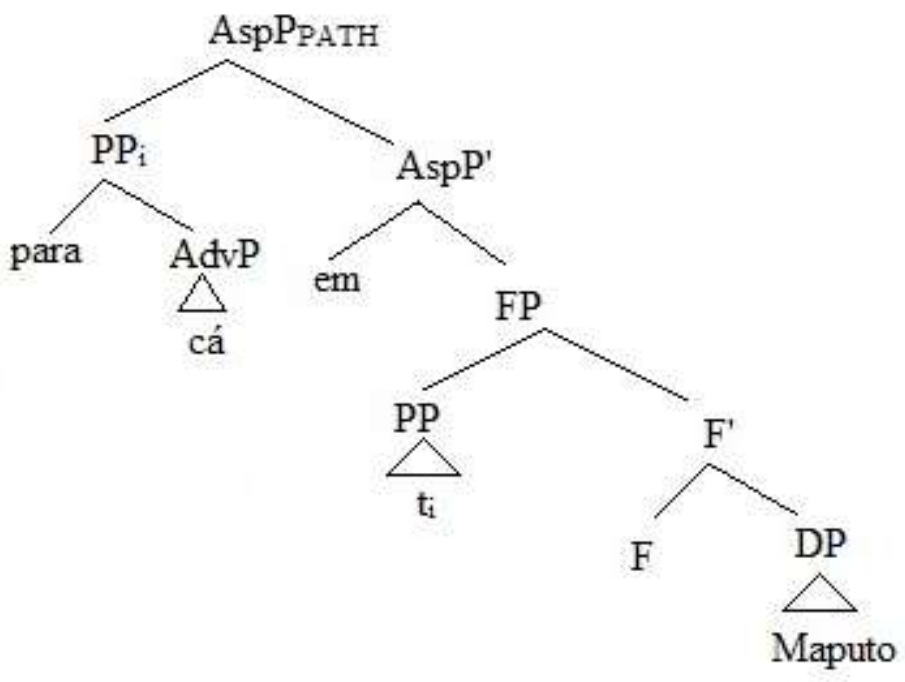

É possível aplicar essa hipótese para estruturas em que notamos a presença da preposição "até", no âmbito da projeção aspectual, que resulta na interpretação aspectual de "ponto limite do deslocamento", como indicam os dados em (18), para os quais cabe, considerando-se nossa hipótese de trabalho, a representação arbórea apresentada em (19):

(18) a. "viemos até em Maxixe."

b. "chegamos até no Maputo" 
c. "imediatamente fomos até em Dar es-Salam"

d. "e voltei até na minha aldeia"

(GONÇALVES, 1990)

(19)

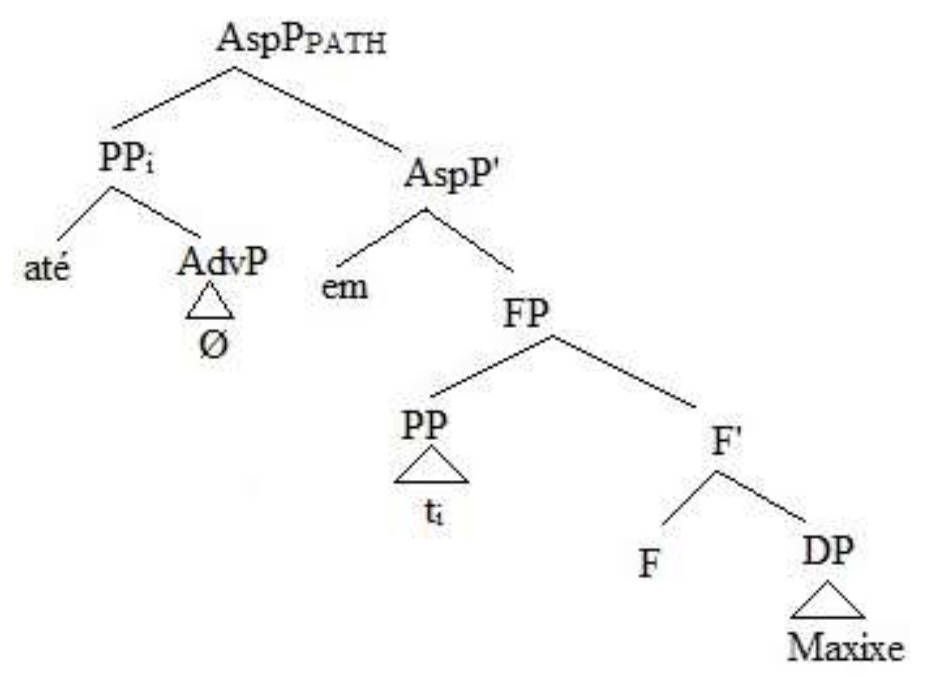

Essa configuração não seria exclusiva do PM, uma vez que o PE apresenta construções semelhantes, diferindo apenas com relação à preposição selecionada em AspP', já que, em vez de "em", no PE, seleciona-se "a". É interessante notar que o uso da preposição “a” na estrutura com a preposição "até" está presente também no PM, conforme ilustrado a seguir:

(20) a. "minha mãe levou-me até ao quilômetro dezesseis"

b. "conseguimos chegar até ao centro"

c. "ainda continuei até ao fim"

d. (as aulas) "iam até ao meio-dia"

(GONÇALVES, 1990)

Dessa forma, entende-se que a preposição "até" denota uma propriedade de aspecto (algo como "ponto limite do deslocamento") prevista tanto pela gramática do PE quanto pela do PM, resguardadas as especificidades desta em relação àquela com relação à seleção da preposição (funcional) licenciadora do DP locativo, já que “em” é encontrada somente no PM. 
Cabe ainda discutir as estruturas em que o PP locativo projeta apenas uma preposição. Ao assumir a configuração proposta por Tortora (2008) para as preposições complexas, e considerando a hipótese de que, nas estruturas com verbos de movimento, a preposição introdutora do locativo é uma categoria funcional, nossa proposta é que a estrutura se mantém a mesma, sendo o DP locativo gerado na projeção FP, conforme indicado a seguir:

(21) a. "nem todos íamos [na mesma escola]"

(GONÇALVES, 1990, p. 250)

$$
\left.\left.\mathrm{a}^{\prime} \text {. [AspP[=path] [Asp, em [FP [F, F [DP a mesma escola }\right]\right]
$$

Como se pode observar, a estrutura proposta mantém a projeção aspectual, a qual, por hipótese, é selecionada na estrutura do predicado de movimento.

Seguem-se dados adicionais com locativos introduzidos pela preposição "em”, com verbos como "carregar", "trazer", de movimento, e também com o verbo "frequentar" que seleciona um DP locativo, embora, em outras variedades (como o PE), sejam usados sem preposição, e ainda um dado em que o locativo introduzido por "em" ocorre exatamente como no $\mathrm{PE}^{22}$ :

(22) a. "mas frequento muito mais [nos cinemas]"

b. "carregávamos um bocado de farinha [em casa]"

c. "os meus irmãos mais velhos traziam giradiscos [em casa]"

d. "O que me contas da situação de lá [em Chimoio]?"23

(GONÇALVES, 1990)

Nesses contextos, a preposição "em" é eleita como marcador funcional prioritário dos sintagmas locativos, ou seja, passou a ter estatuto funcional sempre que associada a Nome locativo, independentemente do componente predicativo.

Os dados sugerem que o uso generalizado da preposição "em" como introdutora do DP/NP locativo, conforme mencionado por Gonçalves \& Chimbutane (2004), relaciona-se com o estatuto que essa preposição assume no PM. Pressupondo-se o caráter funcional da

\footnotetext{
${ }^{22}$ Essa configuração está de acordo com a proposta de Souto (2014) para a estrutura do PP Locativo selecionado pelo verbo "ir" de movimento no $\mathrm{PB}$, em que se verifica o uso da preposição "em" (não "a"). A autora assume a hipótese de Fábregas (2007) (que o PP consiste na projeção dos núcleos funcionais PlaceP e PathP, ambas realizadas pelo lexema "em".

${ }^{23}$ Dado de registro escrito recolhido do corpus organizado por Gonçalves (1990, p. 740).
} 
preposição "em" introdutora do DP locativo, é possível dar conta da ampla distribuição dos PPs introduzidos por "em" no PM. Essa situação se confirma nos dados a serem comentados a seguir, em que verificamos sua ocorrência em outras posições sintáticas.

\subsection{Locativos em posição pré-verbal}

Conforme observado no corpus de Gonçalves (1990), além dos contextos sintáticos analisados na seção anterior, o PM apresenta construções em que PPs locativos, tanto argumentais quanto não argumentais, ocupam a posição inicial da sentença:

(23) a. "[na cidade da beira] eu tinha um tio que já vivia lá há muitos anos”

b. "[na beira] saímos dia cinco"

(24) "[nas cartas de amizade] admite quase todo o tipo de linguagem"

(25) "[Na minha casa] nunca teve dificuldade"

(26) a. "[em casa] estava cheio de pessoas"

b. "[nesses museus] estava muito relacionados com a guerra de libertação não é?"

c. "[neste lugar] está fora do coiso, está fora da cidade"

(GONÇALVES, 1990)

Observando-se o conjunto de dados em (23) a (26), é possível constatar, preliminarmente, diferenças notáveis em relação à estrutura em que os PPs locativos aparecem

na posição pré-verbal.

Em (23a) e (23b), o sujeito dos predicados verbais é referencial, com realização lexical e nula, respectivamente. Considerando-se a hipótese relativa à biargumentalidade dos verbos de movimento, referida na seção 2.2 do presente estudo, o PP locativo em (23b) é argumental, uma vez que o predicado verbal é formado por um verbo de movimento. No caso de (23a), o PP locativo é não argumental, pois não está previsto na grelha argumental do verbo "ter" com interpretação de posse, mas pode aparecer adjunto a ele. Com relação a esses dois primeiros dados, não há dúvidas de que o PP locativo foi movido para uma posição mais alta que não corresponde à posição destinada ao sujeito da sentença, uma vez que tal posição já se encontra ocupada, como se nota pela presença do pronome nominativo "eu", em (23a), e pelos traços de pessoa no verbo "saímos", em (23b). 
Diferentemente de (23), as demais sentenças não apresentam de antemão evidências que apontem que outro sintagma que não o PP locativo esteja ocupando a posição de sujeito da sentença. Então, qual seria a posição estrutural e o estatuto argumental do PP locativo nos casos de (23) a (26)?

Tendo em vista que o PB autoriza construções semelhantes às encontradas no PM, a partir desse ponto serão resgatadas análises presentes na literatura que trata de construções do PB em que sintagmas locativos aparecem em posição pré-verbal, com a finalidade de verificar se os argumentos válidos para o PB também o são para o PM. Isso se torna fundamental para o entendimento acerca do papel sintático que os PPs locativos pré-verbais desempenham no PM.

Pontes $(1986,1987)^{24}$ foi quem realizou os primeiros estudos que apontavam haver no PB construções em que um sintagma locativo ocupa a posição inicial da sentença, que corresponde à contraparte em que o locativo aparece em posição pós-verbal:

(27) a. As gavetas não cabem mais nada. / Não cabe mais nada nessas gavetas.

(PONTES, 1986, p. 17)

b. Essa casa bate bastante sol. / Bate bastante sol nessa casa

(PONTES, 1987, p. 34)

Comparando o posicionamento do elemento locativo em relação ao argumento interno do verbo, Pontes (1987) percebe que a ordem sintagma locativo - sintagma sujeito verbo não é licenciada, conforme demonstrado pela autora nos dados em (28), os quais sugerem haver condições específicas que impliquem a movimentação do locativo para a posição inicial da sentença:

(28) a. *Essa casa bastante sol bate.

b. ${ }^{*} \mathrm{O}$ meu carro $60 \ell$ de gasolina cabe.

(PONTES, 1987, p. 36)

Além disso, o sujeito lógico desse tipo de sentença, quando posposto, não desencadeia concordância com o verbo, o que leva Pontes (1987) a cogitar que esse sintagma

\footnotetext{
${ }^{24}$ A fim de atender aos interesses deste trabalho, utilizamos as análises de Pontes $(1986,1987)$ que tratam apenas dos tópicos-sujeitos locativos, mas ressaltamos que seus trabalhos também abordam as chamadas construções de tópico-sujeito genitivo, como "O carro furou o pneu".
} 
exerça função de objeto na sentença, uma vez que, além de estar posicionado após o verbo, não desencadeia concordância com ele. Ademais, a ocorrência de concordância verbal com o sintagma locativo pré-verbal, como em (27a), induz à interpretação de “As gavetas" como o sujeito da sentença, uma vez que a autora assume que

O sintagma nominal ( $\mathrm{SN}$ ) que vem antes do verbo é o sujeito e o que vem depois é o objeto. A flexão do verbo indica o sujeito, porque o verbo, no português escrito por bons escritores e por pessoas que aprenderam a seguir a regra, deve concordar com o sujeito. A posição e a concordância são os dois critérios formais que no português considerado padrão distinguem as funções gramaticais. (PONTES, 1986, p. 151)

No entanto, Pontes nota que analisar o DP tema posposto ao verbo como objeto é questionável, devido à impossibilidade de substituição desse sintagma por um clítico acusativo, bem como de passivização da sentença:

(28) a. *Esse carro cabe-a.

b. *A gasolina é cabida pela Belina.

(PONTES, 1987, p. 19 e 23)

Em vista disso e tomando como base as construções de tópico-comentário do chinês $^{25}$, a autora considera que o argumento locativo configura um tipo de tópico que, por desencadear concordância quando da posição pré-verbal, deve ser considerado como um tópico-sujeito, sendo o argumento tema o sujeito semântico.

Uma vez que constitui um fenômeno que diferencia o PB em relação ao PE, o tópicosujeito locativo sugere que há uma distinção estrutural entre as gramáticas dessas línguas.

Analisando construções semelhantes às apresentadas em (27), Galves (1998) explicita, com base em Pontes (1987), uma diferença fundamental entre as línguas do mundo no que diz respeito ao sintagma que aparece na posição inicial da sentença. Segundo Galves, algumas línguas são orientadas para o sujeito; outras, para o tópico. No caso das primeiras, a presença de um sintagma que esteja na posição inicial da sentença, mas não seja argumento externo do predicador verbal, exige a manifestação de marcas que estabeleçam correspondência com a estrutura argumental do verbo. Esse é o caso do PE, conforme o seguinte exemplo dado por Galves (1998, p. 21):

\footnotetext{
${ }^{25}$ Um exemplo (traduzido) desse tipo de construção do chinês é: "Aquelas árvores, os troncos são altos" (PONTES, 1986, p. 178). Nesta, nota-se claramente uma distinção entre o elemento tópico e o sujeito da sentença, diferentemente do que apresentam os dados do PB.
} 
(29) Esta casa, bate muito sol nela.

A construção em (29), compatível com o PE, apresenta as seguintes características: i) o locativo não aparece preposicionado; ii) a vírgula demarca, na prosódia, a separação do locativo em relação ao restante do predicado; iii) há um pronome lembrete ("nelas") correferente ao locativo que inicia a sentença, o que indica que esse sintagma, mesmo deslocado, continua exercendo função oblíqua. Segundo Galves (1998), essas são algumas das marcas que comprovam que o PE é uma língua voltada para o sujeito.

Nas línguas orientadas para o tópico, nenhuma dessas marcas se faz necessária à gramaticalidade da sentença, por isso a autora assume ser o PB uma língua voltada para o tópico, uma vez que os dados do PB convergem com essa condição, conforme demonstrado pela autora nos dados em (30):

(30) a. Carpete de madeira não encera.

b. Estas casas batem muito sol *(nelas).

GALVES (1998, p. 22)

Além de não haver as restrições mencionadas anteriormente para os dados do PE, em (30b), observa-se concordância verbal com o locativo e a impossibilidade de inserção de pronome lembrete correferente a esse locativo. Com base nesses fatores, a autora endossa a argumentação de Pontes (1987), a respeito de o PB ser uma língua orientada para o tópico, e defende que a designação mais adequada para as construções em (30) consiste em considerar os DPs pré-verbais como tópicos-sujeitos, ou seja, sintagmas não-argumentais que ocupam a posição sintática de sujeito - SpecTP. Galves (1998, p. 21) destaca que essa orientação não deve ser encarada como uma variação paramétrica, mas sim "como um produto da articulação de diversas parametrizações diferentes". Galves (1998, p. 23) sumariza que, nas estruturas de tópico-sujeito, "não há pronome lembrete retomando o NP anteposto. Não há concordância entre o verbo e o NP pós-verbal. O argumento externo do verbo está ausente.”.

O estudo de Pilati (2006), por sua vez, defende que, mais do que um fator de diferenciação paramétrica do $\mathrm{PB}$ em relação ao $\mathrm{PE}$, os locativos pré-verbais no $\mathrm{PB}$ participam de predicados específicos e são essenciais para a gramaticalidade destes. Voltando-se ao estudo da ordem V-(O)-S no PB, Pilati (2006) constata que a posposição do sujeito ao verbo, 
embora seja mais favorecida em predicados inacusativos, também ocorre com determinados verbos inergativos e transitivos. A autora argumenta que, no PB, há uma estreita relação entre a ordem V-S e a presença de um sintagma locativo com interpretação dêitica na posição inicial da sentença:

(31) a. *Brincam as crianças. / Ali brincam as crianças.

b. *Moram os índios. / Ali moram os índios.

(PILATI, 2006, p. 39)

c. *Em hotéis dormiu a Maria. / Neste hotel dormiu a Maria.

(PILATI, 2006, p. 139)

Em vista dessa exigência, Pilati (2006) defende que as estruturas V-S do PB são instâncias do fenômeno referido como "inversão locativa", em que o sintagma locativo (adverbial ou preposicional) ocupa a posição de sujeito da sentença, ficando o sujeito lógico em posição pós-verbal. Por meio de testes em estruturas de alçamento, a autora demonstra que o sintagma locativo e o sujeito canônico da sentença não podem ocorrer, respectivamente, na posição pré-verbal da oração principal e da encaixada simultaneamente, o que indica uma ligação entre essas posições na sentença, conforme apresenta a autora: ${ }^{26}$

(32) a. Neste lugar parece estar prestes a ser realizada uma batalha.

b. Uma batalha parece estar prestes a acontecer neste lugar.

c. ??Neste lugar parece uma batalha estar prestes a acontecer.

(33) a. Ali parece que brincam as crianças.

b. As crianças parecem que brincam ali.

c. ??Ali as crianças parece que brincam.

(PILATI, 2006, p. 197)

O teste indica que, assim como DPs sujeitos canônicos, os sintagmas locativos também podem ser alçados, contexto em que o locativo alçado bloqueia a possibilidade de o

\footnotetext{
${ }^{26}$ Conforme observa Heloisa Salles (c. p.), é interessante notar que, nos dados em (32), do PB, o sujeito da oração infinitiva, por hipótese, recebe Caso nominativo do infinitivo (flexionado), o que distingue essa estrutura das de alçamento em línguas como o inglês, em que é obrigatório o alçamento do sujeito, uma vez que o Caso nominativo não está disponível (uma vez que o infinitivo é impessoal).
} 
DP sujeito aparecer em posição pré-verbal na oração encaixada (32c), bem como de ser alçado simultaneamente com o locativo (33c), o que significa que apenas um desses sintagmas pode ocupar a posição típica de sujeito da sentença.

Outra evidência de que na inversão locativa o sintagma locativo ${ }^{27}$ ocupa a posição de sujeito está na estrutura de retomada anafórica. Conforme se depreende de (34a), o DP sujeito da oração encaixada é ligado por um antecedente na posição de sujeito. No entanto, em (34b), essa ligação não ocorre, o que confirma que a oração mais alta é uma instância de inversão locativa, sendo a posição de sujeito ocupada por sintagma locativo, conforme exemplifica Pilati (2006, p. 209): ${ }^{28}$

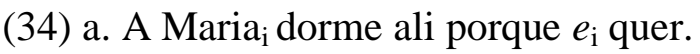

b. *Ali dorme a Maria porque $e_{\mathrm{i}}$ quer.

Acerca da inversão locativa, Pilati (2006) esclarece que as línguas que a autorizam podem diferir quanto ao desencadeamento de concordância entre o locativo e o verbo. Com dados da LB chichewa (35), extraídos de Bresnan e Kanerva (1989 apud Pilati, 2006), e do inglês (36), Pilati exemplifica como a inversão locativa difere nessas duas línguas:

(35) a. Chi-tsíme chi-li ku mu-dzi.

"O poço está na cidade"

b. Ku mu-dzi ku-Ii chi-tsíme.

"Na cidade está o poço"

c. Ku-um-dzi ku-na-bwér-á a-léndo.

"À cidade vieram visitantes"

(PILATI, 2006, p. 175)

\footnotetext{
${ }^{27}$ Em seu estudo, Pilati (2006) traça uma diferenciação entre o PP locativo e o advérbio locativo. Para a autora, o PP locativo é movido para uma posição de adjunção no nível de $\mathrm{CP}$, enquanto o advérbio locativo funciona como sujeito expletivo e, por isso, sai da Numeração diretamente para Spec-TP. Destacamos, então, que, para Pilati (2006), PPs locativos não ocupam a posição canônica de sujeito da sentença.

${ }^{28}$ Segundo Munhoz (2011), Pilati e Naves (2010 apud Munhoz, 2011, p. 39) destacam que a ligação entre o locativo na posição inicial e o sujeito da oração encaixada ocorre em predicados não-causativos:

(i) $\mathrm{Ali}_{\mathrm{i}}$ dormem as crianças porque $e_{\mathrm{i}}$ é mais quente.

Com isso, comprova-se que, assim como um DP sujeito, o tópico-sujeito locativo controla a interpretação da categoria vazia que funciona como sujeito da oração encaixada.
} 
(36) a. In the swamp was/*were found a child.

b. In the swamp were/*was found two children.

(PILATI, 2006, p. 178)

A autora explica que, em chichewa, a manifestação morfológica da concordância verbal, exibida pela presença do morfema "chi", em (35a), e "ku", em (35b-c), tanto no DP pré-verbal quanto no verbo, permite atestar qual elemento exerce função de sujeito na sentença. Nesse sentido, o elemento locativo, que pertence à categoria NP, desencadeia concordância verbal quando preposto ao verbo, como apresentado em (35b-c).

O mesmo não ocorre no inglês, em que, apesar da inversão locativa, a concordância verbal se dá com o sintagma pós-verbal, sujeito da sentença. Isso se assemelha ao que ocorre nas sentenças com o expletivo "there" no inglês, conforme a autora exemplifica:

(37) a. There are/*is infinitely many prime numbers.

b. There is/*are one even prime number.

(PILATI, 2006, p. 178)

A ocorrência do PP em uma posição que, no PE e em tantas outras línguas românicas, é ocupada apenas por DPs é discutida em Avelar (2009), que assume um modelo de configuração sintática em que o PP locativo pertence à projeção LocP (Locative Phrase), cujo núcleo é um advérbio locativo, que pode ou não estar fonologicamente realizado na sentença. Sendo o PP locativo o complemento de LocP, como o autor defende, não haveria entraves para que essa categoria fosse alocada na posição de sujeito gramatical, uma vez que advérbios locativos apresentam estatuto nominal, necessário à valoração dos traços- $\phi$ de $T$.

Em sua proposta, Avelar (2009) não atenta para a marcação casual em construções inacusativas que contêm tópico-sujeito. A pergunta que surge é: qual seria o Caso do sintagma pós-verbal, já que o verbo é incapaz de atribuir Caso acusativo e o Caso nominativo já foi satisfeito pelo PP locativo? Com relação a essa problemática, Avelar \& Galves (2011) apresentam uma proposta de explicação. Para entender essa proposta, faz-se necessário primeiramente discorrer sobre alguns pressupostos adotados pelos autores para tratar da concordância verbal com sintagmas locativos posicionados no início na sentença.

Seguindo a versão minimalista de P\&P, Avelar \& Galves (2011) argumentam que o fato de (38), por exemplo, ser gramatical no PB e agramatical no PE deve-se à diferença do estatuto do EPP de T (doravante $\mathrm{EPP}_{\mathrm{T}}$ ) nessas variedades do português: 
(38) Essas casas batem muito/imenso sol. (*PE / PB)

Para tal sentença se tornar gramatical no PE, seria necessário ou ocorrer uma pausa que marque a atribuição de foco ao locativo deslocado, ou haver concordância do verbo com o sintagma que o sucede, uma vez que este é o sujeito gramatical da sentença.

Diante do contraste apresentado em (38), Avelar e Galves (2011) defendem que, no $\mathrm{PB}$, o $\mathrm{EPP}_{\mathrm{T}}$ é $\phi$-independente, ao passo que, no $\mathrm{PE}, \mathrm{EPP}_{\mathrm{T}}$ é $\phi$-dependente. Isso significa que, no $\mathrm{PB}$, Spec-TP pode receber sintagmas argumentais ou não argumentais, diferentemente do que ocorre no PE, que prevê que Spec-TP seja ocupado somente por um sintagma argumental.

Admitindo o pressuposto de que T herda os traços $u \phi$ de C (cf. Chomsky, 2008), os autores afirmam o seguinte:

\footnotetext{
Se, na satisfação do $E P P_{T}$, a criação de Spec-T é uma condição requerida para satisfazer os traços- $\varphi$ de T, o EPP ${ }_{T}$ será $\varphi$-dependente; em contraste, se Spec-T é criado independentemente dos traços- $\varphi$ de T, o EPP ${ }_{\mathrm{T}}$ será $\varphi$ independente. (...) Essa diferença pode ser vista, a rigor, como indicativa de que $\mathrm{T}$ dispõe ou não de uma condição EPP que lhe seja intrínseca, o que vai determinar se Spec-T é ou não criado depois que T herda os traços $u \varphi$ de C: nos casos de $\varphi$-dependência, Spec-T só pode ser criado após T herdar $u \varphi$; nos casos de $\varphi$-independência, ao contrário, Spec$\mathrm{T}$ pode ser criado tão logo $\mathrm{T}$ seja concatenado à estrutura.

(AVELAR \& GALVES, 2011, p. 52)
}

Partindo desses pressupostos, Avelar \& Galves (2011) defendem que, no PB, o locativo ocupa Spec-TP sem interagir com os traços- $\phi$ de T, haja vista não ser necessária a concordância entre verbo e locativo. Tendo em vista a possibilidade de não ocorrer interação entre os traços- $\phi$ de T e o sintagma que ocupe SpecTP, Avelar e Galves (2011) consideram que o PB é uma língua $\phi$-independente no que tange ao $\mathrm{EPP}_{\mathrm{T}}$. Também por esse motivo, elementos não argumentais podem ser licenciados nessa posição.

Quanto aos casos em que o sintagma locativo estabelece concordância e o verbo é inacusativo, Avelar \& Galves (2011) percebem que falta uma explicação acerca da marcação casual do sintagma pós-verbal. Para preencher essa lacuna, os autores aventam a hipótese de que constituintes nominais talvez possam ser licenciados sem Caso em algumas línguas, uma vez que os traços formais variam parametricamente entre as línguas do mundo. Nesse sentido, haveria dois tipos de línguas no que se refere à obrigatoriedade de Caso ser atribuído a constituintes nominais: i) línguas $[+\mathrm{K}]$ : os DPs sempre apresentam traço de Caso a ser valorado; ii) línguas [-K]: eventualmente, DPs não apresentam traço de Caso a ser valorado. 
Com base nessa hipótese, Avelar \& Galves (2011) argumentam que o DP pós-verbal pode ser licenciado sem Caso, não havendo qualquer implicação disso para a gramaticalidade da sentença. Segundo os autores, o mesmo ocorreria nas sentenças em que o sujeito não apresenta a flexão de concordância verbal, como frequentemente ocorre no PB popular:

(39) Os menino(s) jantou / jantaram.

(AVELAR \& GALVES, 2011, p. 62)

Também interessada nas construções de tópico-sujeito, Munhoz (2011) observa que a realização de DPs nus pós-verbais em construções de tópico-sujeito locativo são mais produtivas no PB que as com DPs plenos, o que diferencia esse tipo de construção de outras construções de tópico-sujeito, como o tópico-sujeito genitivo (40b):

(40) a. Doce não pode entrar água, senão estraga.

b. Meu carro acabou *(a) gasolina.

A autora ressalta que, nos contextos em que o verbo não traz uma informação lexical associada ao locativo, a interpretação do tópico-sujeito como locativo ou genitivo pode ser definida pela presença de DP pós-verbal que seja ou pleno, ou nu, ou indefinido:

(41) a. O campo cresceu grama/um matagal.

b. *Cresceu grama/um matagal do campo.

c. Cresceu grama/um matagal no campo.

d. O campo cresceu a grama.

e. Cresceu a grama do campo.

f. ??Cresceu a grama no campo.

(MUNHOZ, 2011, p. 71-72)

Dos dados infere-se que DPs pós-verbais que sejam nus ou indefinidos associam-se à interpretação locativa, ao passo que os plenos remetem à interpretação genitiva.

Munhoz também atenta para o fato de que não é simplesmente a realização de um sintagma locativo na posição inicial da sentença que caracteriza as construções de tópicosujeito locativo no PB. Segundo ela, somente os verbos inacusativos biargumentais não 
permitem a omissão do elemento locativo e podem desencadear concordância com ele (42), diferentemente do que ocorre nos predicados com verbos monoargumentais, como os inergativos (43) ou inacusativos canônicos (44):

(42) a. *Bate sol.

b. Essas casas batem sol.

(43) a. Nadaram os melhores da equipe.

b. *A piscina nadou os melhores da equipe.

(44) *Aquela pia quebrou um copo.

(MUNHOZ, 2011, p. 78 e 79)

Admitindo que um sintagma locativo de caráter obrigatório que venha a ocupar a posição inicial da sentença é um argumento do predicado verbal, a autora endossa a argumentação a favor de que os verbos dessas construções são inacusativos biargumentais, isto é, são verbos que não projetam argumento externo, mas sim dois argumentos internos (um tema e outro locativo). Nessas construções, ambos os argumentos concorrem para ocupar a posição de sujeito, o que pode derivar, no PB, uma ordem [DP V PP], [V DP PP], ou [DP V DP], conforme apresentado respectivamente nos dados:

(45) a. O sol bate nessa casa.

b. Bate sol nessa casa.

c. Essa casa bate sol.

Acerca da projeção sintática de estruturas como (45b) e (45c), Munhoz (2011) propõe uma diferenciação fundamental entre elas no que se refere à Numeração e ao posicionamento do argumento tema e do argumento locativo em Spec-VP.

Por se tratar de um predicado projetado por um verbo inacusativo, assume-se que não há projeção de $v \mathrm{P}$, uma vez que não há argumento com papel temático externo. Em vista disso, Munhoz (2011) defende que, em (45b) - cuja representação arbórea apresentamos em (46) —, o argumento tema permanece em posição pós-verbal porque $\mathrm{T}$ é defectivo com relação ao traço EPP, por isso não se realiza a operação Move sobre esse argumento: 
(46)

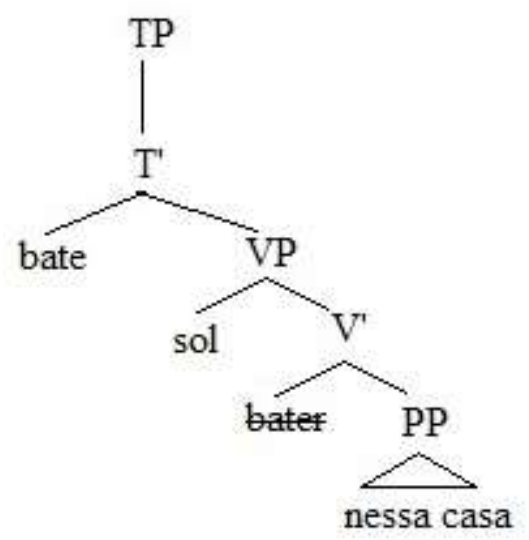

(MUNHOZ, 2011, p. 118 [com adaptações])

Segundo Munhoz, a razão de o DP estar projetado em Spec-VP consiste na sequência de merges que acontecem na derivação. Como a preposição realiza o primeiro merge com o DP "casa", formando o PP locativo, que, por sua vez, estabelece merge com o verbo, sobra apenas a posição de especificador de VP para o DP "sol". Como esse sintagma não se move para Spec-TP, posição em que tipicamente é marcado o Caso nominativo, Munhoz assume que, nessa configuração, o Caso é atribuído no componente morfológico, após Spell-out, na forma de Caso default. Para a autora, dados como os apresentados em (47) respaldam o argumento de que o Nominativo é o Caso default no PB:

(47) Eu bem que tentei levar minhas coisas na mala, mas num coube elas na mala não!

(MUNHOZ, 2011, p. 119)

No caso de (45c), cuja projeção sintática está apresentada em (48), a autora assume, com base em Lunguinho (2006 apud Munhoz, 2011), que não há preposição na Numeração composta pelos itens lexicais que formam essa sentença. Nessa situação, o primeiro merge se dá entre o verbo e o argumento tema, restando ao locativo a posição de Spec-VP, da qual deverá se mover para valorar seu Caso via Agree em Spec-T. Nesse caso, considera-se que T é rico em traços- $\phi$ e EPP, haja vista tanto a movimentação do DP locativo quanto a possibilidade de concordância dele com o verbo: 


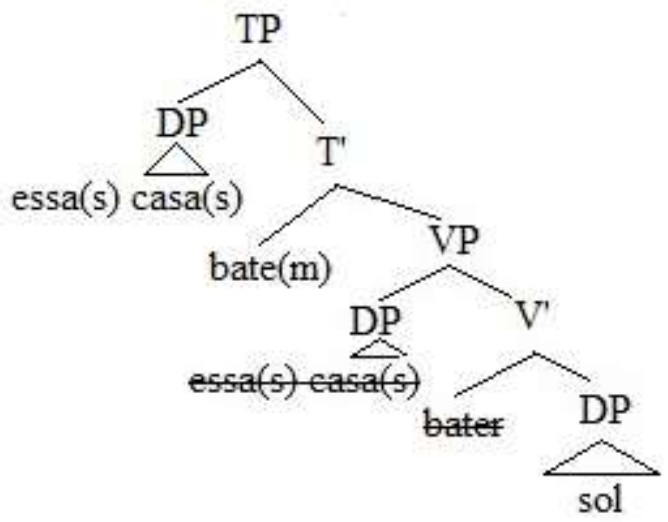

Dada a satisfação dos traços em T, Munhoz (2011) propõe que o DP tema comporta Caso (Nominativo) default também nessa configuração. Assim, a única ordem em que esse sintagma valora seu Caso estruturalmente é [DP V PP].

Levantando mais argumentos para confirmar o caráter argumental tanto do DP tema quanto do PP/DP locativo em predicados inacusativos biargumentais, Munhoz (2011, p. 86) sinaliza que tais sintagmas podem formar ilhas fracas porque possuem estatuto argumental, ao contrário de adjuntos:

(49) O motorista não sabe se vai caber toda a mudança no caminhão / o caminhão vai caber toda mudança.

a. $O$ que $_{\mathrm{i}}$ (que) o motorista não sabe [se vai caber $t_{\mathrm{i}}$ no caminhão]?

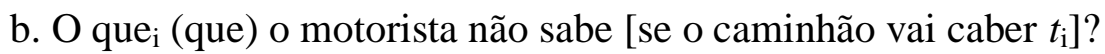

c. Onde $\mathrm{i} / \mathrm{em}$ que $\mathrm{i}$ (que) o motorista não sabe [se vai caber toda a mudança $t_{\mathrm{i}}$ ]?

d. Onde $\mathrm{i}_{\mathrm{i}} / \mathrm{em}$ que $_{\mathrm{i}}$ (que) o motorista não sabe [se toda mudança vai caber $t_{\mathrm{i}}$ ]?

e. Onde ${ }_{\mathrm{i}} / \mathrm{o} \mathrm{que}_{\mathrm{i}}$ (que) o motorista não sabe [se $t_{\mathrm{i}}$ vai caber toda a mudança]?

(50) O João não sabe se o motorista trabalha nessa firma.

a. ${ }^{*}$ Onde $_{\mathrm{i}}$ (que) o João não sabe [se o motorista trabalha $t_{\mathrm{i}}$ ]?

A aplicação dos testes em (49) comprova que DP-tema e DP-locativo, respectivamente, comportam-se como argumentos, uma vez que podem ser extraídos para formarem ilhas, ao contrário do que acontece com adjuntos em (50). 
Com relação à projeção do tópico-sujeito locativo na estrutura sintática, Munhoz \& Naves (2012) discutem a proposta de Pilati \& Naves (2012 apud Munhoz e Naves, 2012) acerca da existência de uma projeção intermediária, não atribuidora de Caso, entre $\mathrm{T}$ e $\mathrm{C}$ que abrigue os sintagmas tópico-sujeito locativos. Nessa proposta, entende-se que a referencialidade conferida pelo locativo em posição de tópico decorre da transferência de traços de C para essa projeção intermediária, chamada de $\alpha$-P (cf. Miyagawa, 2010).

Munhoz \& Naves (2012) explicam que o postulado da projeção $\alpha \mathrm{P}$ prevê que línguas orientadas para o tópico disponham dessa projeção, o que constitui uma distinção paramétrica em relação às línguas orientadas para o sujeito, conforme as autoras sintetizam:

(i) traços- $\varphi$ e traços de tópico"foco herdados por $\alpha$ : línguas de proeminência de tópico (Agreement não desencadeado por Caso);

(ii) traços- $\varphi$ e traços de tópico"foco herdados por $\mathrm{T}$ : línguas de proeminência de sujeito (Agreement desencadeado por Caso)

(MUNHOZ \& NAVES, 2012, p. 259)

Adotando essa perspectiva de análise, as autoras defendem que, nas construções de tópico-sujeito locativo do $\mathrm{PB}$, tanto o DP locativo pré-verbal, posicionado em Spec- $\alpha \mathrm{P}$, quanto o DP tema pós-verbal não apresentam traços de Caso na derivação, uma vez que T não recebe traços de $\mathrm{C}$ nesse caso e não há preposição na Numeração para atribuir Caso ao sintagma locativo. Assim, considera-se que ambos os DPs têm Caso atribuído no componente morfológico.

Tendo em vista as contribuições dos estudos do PB referidos até este ponto, retornamos à discussão acerca dos dados do PM apresentados inicialmente em (23-26).

Reiteramos, primeiramente, os dados em (23), repetidos aqui em (51):

(51) a. "[na cidade da beira] eu tinha um tio que já vivia lá há muitos anos"

b. "[na beira] saímos dia cinco"

(GONÇALVES, 1990)

Nesses dados, a anteposição do PP locativo é prevista da mesma forma no PE e no PB nas construções de tópico. Observa-se que os dados (51) não configuram construções de tópico-sujeito, uma vez que em ambos o argumento externo dos verbos está presente, ainda que representado por uma categoria vazia - como no caso de (51b). Além disso, é curioso notar que, em (51a), o advérbio locativo "lá", presente na oração relativa, retoma o PP 
locativo topicalizado, semelhante ao que ocorre nas construções de tópico locativo no PE, conforme destacamos da explicitação de Galves (1998) ${ }^{29}$. A exclusão desse "advérbio lembrete" pode, por hipótese, acarretar, senão a agramaticalidade da sentença, no mínimo uma mudança de sentido. Por essa perspectiva de análise, considera-se que os dados em (51) são exemplos de locativos oblíquos topicalizados. Contudo, tal análise não se aplica a outros dados do PM.

Abaixo constam alguns dados do PM pelos quais não se pode precisar, de antemão, se o locativo em posição inicial está apenas ocupando uma posição de tópico em $\mathrm{CP}$ (explodido) ou se está ocupando a posição sintática de sujeito:

(52) "[nas cartas de amizade] admite quase todo o tipo de linguagem"

(53) "[nas escolas] não dão certificados de habilitação"

(54) a. "[Na minha casa] nunca teve dificuldade"

b. "[em cada escola] tinha capacidade para albergar seiscentos alunos"

c. "[na minha província] não tem décima nem décima primeira!”

(GONÇALVES, 1990)

Nesses dados, notam-se construções com diferentes tipos de verbos, em que se identificam diferentes possibilidades de análise, embora da relação entre as mesmas seja possível extrair uma generalização, como veremos. Em (52) e (53), os verbos são transitivos e não preveem um sintagma locativo em sua estrutura argumental. Em (53), o verbo na terceira pessoa do plural permite uma interpretação indefinida/genérica do sujeito (em conformidade com o PE). No entanto, em (52), o verbo está na terceira pessoa do singular, e sua realização no presente do indicativo licencia uma interpretação indefinida/genérica do sujeito (embora não ocorra o pronome "se", marcador formal dessa interpretação, em conformidade com o $\mathrm{PE}$ ). A estrutura (52), em particular, permite um paralelo com o $\mathrm{PB}$, em que é recorrente o uso de estruturas com sujeito indefinido/genérico na terceira pessoa do singular, sem o pronome “se" (cf. GALVES 2001), sendo postulado um sintagma adverbial locativo/temporal (nulo) na posição de sujeito como o correlato formal desse pronome (cf. PILATI, 2006; PILATI \& NAVES, 2013).

\footnotetext{
${ }^{29}$ Ver página 58 desta dissertação.
} 
Comparativamente, os predicados de (52) e (53) se distinguem pelo fato de que apenas (53) é ambíguo quanto à sintaxe do sujeito da sentença, uma vez que tanto o PP locativo quanto o verbo estão no plural, diferentemente de (52), em que há diferença de número entre o sintagma pré-verbal e o verbo, o que permite afirmar que, em (52), o PP locativo não está na posição de sujeito, portanto não se trata de uma construção de tópicosujeito, nos termos de Pontes (1987), Galves (1998), Munhoz (2011) e Munhoz \& Naves (2012).

Por outro lado, o emprego do verbo "ter" sem um DP sujeito explícito nas construções em (54) as torna ambíguas, uma vez que admitem uma realização sintática tanto de predicado existencial quanto de predicado transitivo (possessivo). Na realização como predicado existencial, os PPs na posição inicial da sentença têm caráter argumental no estrutura predicado com o verbo "ter" (existencial), enquanto na realização como transitivo (possessivo), o verbo "ter" seleciona dois argumentos, e o PP é interpretado como o argumento possuidor, embora seja marcado como locativo (semanticamente um caso em que os indivíduos/habitantes são tomados pelo local em que atuam/vivem, contexto em que (54ac) são, respectivamente, equivalentes a Minha casa nunca teve dificuldade/Cada escola tinha capacidade de albergar.../Minha província não tem décima...).

A fim de compreender a distinção dos dados do PM em relação aos dados do PB, apresentamos a seguinte tabela, elaborada por Pilati (c.p.) ${ }^{30}$. Nessa tabela, são sumarizados os tipos de construções do PB em que ocorre sintagma locativo na posição inicial da sentença:

\begin{tabular}{|c|c|c|c|c|c|}
\hline construção & Exemplo & $\begin{array}{c}\text { frequência } \\
\text { no PB }\end{array}$ & estatuto do DP locativo & Sujeito & $\begin{array}{l}\text { concordância } \\
\text { com o tópico }\end{array}$ \\
\hline tópico-sujeito & $\begin{array}{l}\operatorname{Essa}(\mathrm{s}) \text { casa(s) } \\
\text { bate }(\mathrm{m}) \text { sol. }\end{array}$ & alta & $\begin{array}{l}\text { argumento do predicador } \\
\text { verbal; } \text { ocorre com } \\
\text { inacusativos biargumentais. }\end{array}$ & +definido & Sim \\
\hline $\begin{array}{l}\text { inversão } \\
\text { locativa }\end{array}$ & $\begin{array}{l}\text { Aqui dormem } \\
\text { as crianças. }\end{array}$ & baixa & adjunto $(\mathrm{CP})$; expletivo (TP) & +definido & Não \\
\hline $\begin{array}{l}\text { novos sujeitos } \\
\text { indefinidos }\end{array}$ & $\begin{array}{ll}\text { Aqui } & \text { vende } \\
\text { sorvete. } & \end{array}$ & alta & adjunto (CP); expletivo (TP) & -definido & Não \\
\hline
\end{tabular}

Com base nessas definições, é possível concluir que, pelo menos para os dados levantados neste estudo, o PM não apresenta construções de tópico-sujeito, mas apresenta o

\footnotetext{
${ }^{30}$ Agradeço à profa. Eloísa Pilati (p. c.) pelas observações elencadas na tabela e pelas contribuições para a discussão levantada neste estudo. Agradeço igualmente à professora Zenaide Teixeira (c. p.) por ressaltar a necessidade de discutir a concordância como diagnóstico para analisar a sintaxe dos predicados citados.
} 
fenômeno da inversão locativa, considerando-se a leitura existencial de (54), e os denominados "novos sujeitos indefinidos", classificação que pode ser preliminarmente atribuída a (52) e (53).

Portanto, os dados em (52-54) evidenciam que o posicionamento do locativo no início da sentença pode ocorrer em diferentes tipos de predicado, o que significa que essas construções podem ser licenciadas com sintagma locativo argumental ou não argumental no PM. Conforme apresentado anteriormente, as LB autorizam a inversão locativa nos mesmos contextos observados nos dados do PM. Levando-se em consideração o papel da L1 no processo de aquisição do português em Moçambique, pode-se pressupor que a autorização de inversão locativa no PM é resultado de reanálise do português com base nas propriedades gramaticais das LB.

Além dos predicados inacusativos, inergativos e transitivos, há ainda outro tipo de dado no PM, em que os PPs locativos ocorrem na posição de DPs sujeitos, conforme apresentado em (26). A próxima subseção é dedicada a tratar de tais dados.

\subsubsection{PPs locativos em posição pré-verbal em predicados com cópula}

No PM, há construções com predicados copulativos ("ser" / "estar") em que o PP locativo inicia a sentença, ocupando, por hipótese, a posição de sujeito, apesar da ausência de concordância, conforme apontam os seguintes dados:

(55) a. "[em casa] estava cheio de pessoas"

b. "[nesses museus] estava muito relacionados com a guerra de libertação não é?"

c. “[no Chokwé] já não já era um pouco mais movimentado"

d. "os alunos estavam formados em fila e [no meio] estava vazio"

e. "[neste lugar] está fora do coiso, está fora da cidade"

(GONÇALVES, 1990)

Sabe-se que, em predicados com cópula, o verbo não possui caráter predicador, mas é concatenado com uma small-clause (SC). Isso significa que, nesses predicados, o argumento é alçado à posição de sujeito, estabelecendo relações temáticas com o elemento predicativo no domínio da SC. Assim, para uma sentença como "João é valente", seria compatível a seguinte representação sintática (cf. MIOTO et al., 2005): 


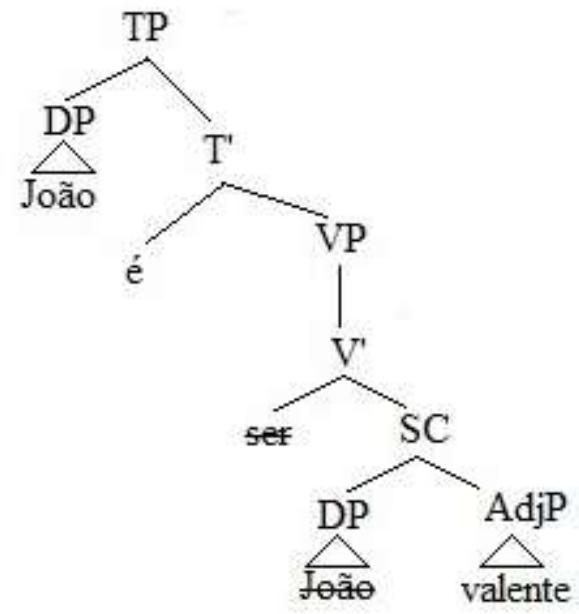

Assim como os verbos inacusativos, os verbos copulativos não selecionam argumento externo e, por esse motivo, são incapazes de atribuir Caso ao DP internamente. Além disso, na estrutura funcional o traço EPP de $\mathrm{T}$ deve ser valorado, bem como os traços- $\varphi$ não interpretáveis, realizados morfologicamente na estrutura do verbo. Portanto, T atua como uma sonda, que busca o elemento mais próximo que possua traços- $\varphi$ interpretáveis, o qual se move para a posição de sujeito da sentença.

A estrutura com a cópula "ser", em (56), se aplicaria também àquelas com um PP locativo, por hipótese, realizado na posição de sujeito, ilustradas a seguir:

(57) a. Em casa é um bom lugar ficar.

b. Embaixo da cama é bom para guardar o sapato.

c. No céu é lugar dos anjos.

Com relação aos dados em (55), é possível postular que o PP locativo forma a SC selecionada por VP. Evidência de que o PP locativo estabelece relação estrutural com o sintagma adjetival no âmbito da SC é a manifestação de concordância entre o particípio adjetival e o nome no PP locativo, como em (55b). Assim, por hipótese, o PP locativo ocupa a posição que um DP ocuparia em sentenças copulativas, sendo alçado a partir da SC na estrutura do predicado.

Em uma análise que considere que o PP locativo se move para Spec-TP, é possível entender que o PP fica visível para a Sonda em T porque a preposição apresenta estatuto 
funcional, de acordo com a proposta de PP shell assumida neste estudo. Por outro lado, tendo em vista a falta de concordância entre o argumento locativo e o verbo, também seria plausível pressupor que o PP se move para uma posição mais alta que TP e, talvez, mais baixa que CP. Nessa perspectiva, é possível supor que o PP locativo é alçado para uma posição intermediária, definida como Spec- $\alpha$ P. Por hipótese, essa posição abriga tópicos-sujeitos, segundo Miyagawa (2010 apud Munhoz e Naves, 2012), embora não tenha traços formais que permitam licenciar o Caso nominativo, o que explica que não haja concordância ${ }^{31}$.

Embora seja possível a construção de cópula com sujeito preposicionado no PE, a exemplo da sentença "Em cima da cama é um bom lugar (para colocar o travesseiro)", os dados do PM revelam uma inovação em relação ao PB e ao PE. Tal inovação consiste em licenciar estrutura de cópula com sujeito PP cópulas com o verbo "estar", em uma relação atributiva, como em (55a-b) e (55d), ou mesmo locativa, como em (55e).

Conforme referido na seção 3.1 deste capítulo, as LB autorizam predicados com cópula cujo sujeito seja um argumento locativo. Repetimos a seguir o dado da LB changana, que exemplifica tal fenômeno, extraído de Gonçalves \& Chimbutane (2004), seguido do julgamento de gramaticalidade para a tradução da sentença, no PE e no PB :

\section{(58) Kerek-eni i ku-tsongo \\ 9igreja-loc é 17-pequeno}

"Na nossa igreja é pequeno.” (*PE / *?PB)

(GONÇALVES \& CHIMBUTANE, 2004, p. 18)

Portanto, além das propriedades apontadas nas seções anteriores, em que os dados levantados demonstram que PB, PM e PB ora se diferenciam, ora se aproximam, constatou-se que, entre essas três variedades, somente o PM autoriza a ocorrência de PP locativo pré-verbal com "ser" e "estar", o que pode ser resultante do contexto de transmissão linguística específico de Moçambique.

\footnotetext{
${ }^{31}$ Foge aos propósitos do presente trabalho aprofundar a discussão a respeito das construções de cópula, por ser um tema que requer considerações adicionais de ordem teórica e empírica. Por isso, limitamo-nos a levantar a discussão, a fim de ensejar pesquisas futuras sobre o assunto, ressaltando a importância dos dados do PM para a análise desse tema.
} 


\section{CAPÍTULO 4}

\section{ARGUMENTOS LOCATIVOS NA VARIEDADE BRASILEIRA E EM VARIEDADES AFRICANAS DA LÍNGUA PORTUGUESA: A HIPÓTESE DO CONTATO}

Neste capítulo, levantam-se descrições e análises presentes na literatura que aborda as propriedades dos sintagmas locativos em variedades da língua portuguesa como decorrentes do contato interlinguístico. Com este capítulo, não se pretende construir uma argumentação em defesa da hipótese do contato, mas abordar de que forma a literatura tem indicado esse fator entre o conjunto de propriedades que teriam induzido às realizações desviantes presentes no PB e no português falado em países africanos. Para tanto, o capítulo está dividido nas seções: 4.1., na qual são expostas pesquisas que defendem a aproximação entre os empregos dos sintagmas locativos no PB e em línguas africanas, especialmente LB; e 4.2., na qual se descrevem alguns dados do português falado em Guiné-Bissau, em Angola e em São Tomé e Príncipe, a partir dos quais almejamos levantar mais discussões e instigar o interesse pela pesquisa acerca das variedades africanas do português.

\subsection{Aproximações entre o português brasileiro e línguas africanas}

No território brasileiro, o contato do português com línguas africanas iniciou-se no final do século XVI, quando a coroa portuguesa passou a adotar o tráfico negreiro na colônia brasileira. De fato, os estudos sobre a formação do português brasileiro são unânimes ao estabelecer esta correlação, como aponta Mattos e Silva (2002), em obra que reúne estudos prévios que incluem a contribuição dos estudos clássicos de Serafim da Silva Neto, Paul Teyssier, Antonio Houaiss, sobre a língua portuguesa no Brasil, e subsequentes, Aryon Rodrigues sobre as línguas indígenas, Alberto Mussa, Emílio Bonvini, sobre a influência de línguas africanas, além dos estudos de antropólogos notáveis, como Darcy Ribeiro, e de historiadores, como John Manuel Monteiro.

Tendo em vista que o sistema escravocrata perdurou até o final do século XIX, o contato mais intenso do português com as línguas africanas faladas pelos escravos aconteceu nesse intervalo, que durou mais de 300 anos, período em que também nasceram descendentes desses escravos, que adquiriram uma forma do português estruturada pelas gerações anteriores, conforme aponta Lucchesi (2003, 2008). 
Apesar do considerável contingente populacional africano no Brasil durante o período colonial, que coincide com o período de formação do $\mathrm{PB}$, nem todos os estudos acerca da formação dessa variedade compartilham da hipótese de que o contato interlinguístico determinou as diferenças gramaticais que se verifica atualmente no PB, mas não no PE.

Naro \& Scherre (1993), entre outros autores que defendem a hipótese da deriva linguística, argumentam que todas as propriedades gramaticais existentes no PB são fruto da evolução natural da língua portuguesa, e não decorrentes de eventuais contatos que tenha havido com qualquer outra língua. Na obra Origens do Português Brasileiro, em que recorrem a resultados de pesquisas sociolinguísticas, de base laboviana, para respaldar a tese da deriva, os autores afirmam o seguinte:

\footnotetext{
É importante notar que não estamos querendo afirmar que os falantes nativos de línguas africanas ou indígenas do Brasil tenham adquirido a língua portuguesa com fluência nativa, nem que os falantes nativos de português não tenham introduzido em sua fala traços africanos, indígenas, pidginizantes ou não, das línguas gerais e até mesmo da chamada "língua de preto", esta última bastante arraigada em Portugal, pelo menos desde o século XV, e usada para comunicação com africanos tanto na África como na Europa (...). (NARO \& SCHERRE, 2007, p. 28)
}

Nesse sentido, entende-se que quaisquer construções que sejam encontradas no PB, mas não no PE, em determinado intervalo de tempo, podem tanto ter sido utilizadas de forma corrente em outro momento da história do PE ou estão latentes na gramática dessa língua, podendo ser ativadas a qualquer momento.

O outro conjunto de pesquisadores, pautado na hipótese do contato, defende que a emergência de certas propriedades gramaticais no PB que não são encontradas no PE deve-se ao contato do português com diferentes línguas no território brasileiro, conforme dispõem Lucchesi (2001, 2003), Castro (2006), Petter (2006, 2008), entre outros. Nessa perspectiva, estimam que o contato interlinguístico, principalmente o que envolveu línguas de origem africana, tenha interferido de forma substancial no processo de formação do PB.

Para Mattos e Silva (2002), a população africana aportada no Brasil na condição de escrava foi quem atuou mais intensivamente na difusão do português em diversos pontos do território brasileiro. Ao terem tido de abdicar de suas línguas maternas em prol da língua do colono, esses africanos incluíram propriedades daquelas línguas nesta, a fim de "facilitar" o processo de aquisição. Com isso, o português fora profundamente reformatado pelos africanos e seus descendentes nascidos em território brasileiro, afirma Mattos e Silva (2002). 
No entanto, nem todos os pesquisadores que assumem a hipótese do contato o fazem com base na mesma argumentação. Por exemplo, Holm (1987 apud Avelar \& Galves, 2013) aventa a hipótese de que o PB passou por um estágio de crioulização, ao passo que Lucchesi (2003) defende ter ocorrido um processo de transmissão linguística irregular do tipo leve, responsável por muitas das propriedades que caracterizam as variedades populares do PB.

Em vista dos objetivos do presente estudo, não pretendemos explorar de forma mais profunda essa discussão teórica, mas, juntamente a Petter (2009), assumimos que há fortes indícios de que as línguas africanas exerceram papel fundamental na gênese de propriedades que são encontradas no PB e em variedades africanas do português, mas não no PE:

\begin{abstract}
São tantas as semelhanças compartilhadas pelas variedades brasileira, angolana e moçambicana de português, que fica difícil defender que tais fatos sejam casuais, resultantes de uma deriva natural do português ou decorrentes da manutenção de formas antigas do PE. Por que as mesmas áreas da gramática do português foram "perturbadas"? A hipótese de que essas mudanças tenham sido introduzidas por falantes de línguas africanas, tanto na África quanto no Brasil, impõe-se de forma contundente, mesmo que se considere que no Brasil falantes de línguas indígenas e de outras línguas europeias tenham participado da constituição do PB. É provável que o contato com as LB (línguas do grupo banto) não seja a única explicação para as mudanças observadas no PB, mas esse contato é com certeza bastante relevante. (PETTER, 2009, pp. 171-172)
\end{abstract}

Considerando os pressupostos da Teoria Gerativa em relação à mudança linguística em face da transmissão irregular, conforme sistematizado em Roberts (2007), e partindo de dados, como (1) a (4), do PB, Avelar \& Cyrino (2008) levantam evidências em favor da argumentação de proximidade sintática entre dados do PB e as construções de inversão locativa das LB, que permitem concluir que se trata de instâncias de inversão locativa:

(1) verbos inacusativos
a. Na casa da Maria chegou algumas cartas.
b. No meio da festa apareceu uns convidados estranhos.
c. Naquele documento consta o nome da Maria.

(2) verbos inergativos

a. Naquele quarto dormiu várias pessoas.

b. Naquela fábrica trabalha muitos amigos meus.

c. Na universidade estuda a filha de uma amiga minha. 
(3) verbos transitivos ergativizados

a. Naquele bairro aluga casa de todos os preços.

b. Na loja do Pedro não conserta sapato de couro.

c. Naquele fazenda plantava beterraba.

(4) verbos transitivos e inergativos sem tema e/ou agente

a. Nas cidades do interior não seqüestra tanto como nas grandes capitais.

b. No casa do João cozinha todos os dias.

c. Na casa da Maria dorme cedo.

(AVELAR \& CYRINO, 2008, p. 61)

Nesse aspecto, a análise de Avelar \& Cyrino (2008) é comparável à de Pilati (2006), ao recorrer à estrutura de inversão locativa para dar conta de um fenômeno característico do PB. No entanto, a primeira, mas não a segunda, adota a hipótese do contato. Conforme demonstrado no capítulo anterior, Pilati (2006) afirma que a ordem V-S do PB é licenciada na presença de um sintagma adverbial (lexicalmente realizado ou nulo), situado em uma configuração de inversão locativa, que satisfaz uma variável dêitica (temporal ou locativa) introduzida pelo predicado. Para Avelar \& Cyrino (2008), a presença da inversão locativa nas gramáticas das LB faladas pelos escravos constitui um argumento para explicar a existência dessas construções no PB, mas não no PE.

Recorrendo ao contraste em (5), originalmente proposto na argumentação de Pilati (2006), os autores demonstram que o PB e o PE diferem no que diz respeito à interpretação do sintagma locativo pré-verbal:

(5) a. Ele $\mathrm{i}_{\mathrm{i}}$ disse que naquela loja $c v_{\mathrm{k}}$ vende livros. $(\mathrm{PB} / * \mathrm{PE})$

b. Ele $e_{i}$ disse que naquela loja $c v_{\mathrm{i}}$ vende livros. (*PB / PE)

Avelar \& Cyrino explicam que a única interpretação possível no PE é (5b), na qual o sujeito da oração encaixada é correferente ao sujeito da oração principal, conforme demonstrado pelo índice exposto na categoria vazia $(c v)$. Por outro lado, no PB a interpretação que se tem de (5a) remete a um sujeito não especificado na sentença, a exemplo do que acontece no PE com o emprego do pronome "se" indeterminador de sujeito. 
Para Avelar \& Cyrino, atribuir a (5a) uma leitura de sujeito indeterminado acarretada pelo desuso do pronome "se" seria insuficiente para explicar o fenômeno, uma vez que, estando nessa posição, o locativo pode ser decisivo para a gramaticalidade da sentença. Isto é, a exclusão do locativo torna a sentença agramatical, conforme demonstrado em (6):

(6) *Vende muitos livros.

Por meio de dados recolhidos de Bresnan \& Kanerva (1989 apud Avelar \& Cyrino, 2008), os autores atestam a ocorrência da inversão locativa na LB chichewa ${ }^{32}$ :

(7) a. ku-um-dzi ku-na-bwér-á a-lendô-wo

17-3-village SC17-PAST-come-FV 2-visitors-those

"To the village came those visitors."

b. m-mi-têngo mw-a-khal-a a-nyăni

18-4-tree SC18-PERF-sit-FV 2-baboons

"In the trees are sitting baboons."

(AVELAR \& CYRINO, 2008, p. 60)

Segundo os autores, Bresnan \& Kanerva (1989 apud Avelar \& Cyrino, 2008) observam que a inversão locativa no chichewa apresenta as seguintes propriedades: i) ocorre somente com verbos inacusativos; ii) o verbo concorda com o sintagma locativo que o precede, como se nota pela indicação dos morfemas das classes 17 e 18, respectivamente, em (7a) e (7b), o que denota ser o sintagma locativo o sujeito da sentença.

Se essas fossem as únicas condições que licenciam a inversão locativa em chichewa, não seria possível estender a mesma análise para os dados do PB com verbos transitivos. Em vista disso, Avelar \& Cyrino apresentam dados de outras duas LB, o setswana (8) e o kinyarwanda (9), que admitem a inversão locativa com verbos inergativos e transitivos, desde que não haja argumento agente e tema ao mesmo tempo na sentença:

\footnotetext{
32 Assim como nas outras LB, em chichewa a concordância verbal é explicitada pela inclusão no verbo do morfema classificador presente no DP sujeito. Em (7a), trata-se do morfema da classe 17 (ku-); em (7b), é o morfema da classe 18 .
} 
(8) Mó-le-fátshé-ng gó-fúla di-kgomo

18-5-country 17SM-graze 10-cattle

"In the country are grazing the cattle."

(9) a. kw’ íisôko ha-Ø-guz-w-e ibi-íntu bi-taandátu

in market 16-PST-buy-PAS-PRF 8-thing 8-six

"At the market were bought six things."

b. um cyûmba ha-Ø-ríi-r-iye umwáana

in room 16-PST-eat-APL-PRF 1 :child

"The child ate in the room."

(AVELAR \& CYRINO, 2008, p. 60)

Considerando que, em um contexto de aquisição de L2, estruturas menos marcadas, ou seja, que exigem menos operações sintáticas, são preferidas pelo falante para lidar com a falta de transparência, Avelar \& Cyrino (2008) defendem que a aquisição do português pelos africanos no Brasil envolveu a marcação de um parâmetro que permite o licenciamento da inversão locativa no PB. Pelas projeções sintáticas expostas abaixo, os autores buscam demonstrar que forma a construção de inversão locativa é menos marcada (mais econômica) que a topicalização do locativo que ocorre no $\mathrm{PE}^{33}$ :

\footnotetext{
${ }^{33}$ As estruturas propostas em (10) requerem elaboração em alguns aspectos, que não estão explicitados na análise de Avelar e Cyrino. Por exemplo, a presença de pro em specTP, por movimento a partir de vP, pressupõe a leitura referencial específica para o argumento externo do verbo 'vender'. No entanto, na estrutura do PB, não há qualquer referência ao licenciamento do argumento externo do verbo 'vender', particularmente ao fato de que, nessa configuração, o argumento externo recebe leitura arbitrária, obrigatoriamente. Pilati e Naves (2013) argumentam que, com a realização do sintagma locativo em specTP, na inversão locativa, permanecem em VP o argumento externo de verbos intransitivos e o argumento interno de verbos inacusativos e transitivos - no caso dos transitivos, o argumento externo terá leitura arbitrária necessariamente. Agradeço à Heloisa Salles (c. p.) pela observação.
} 
(10)

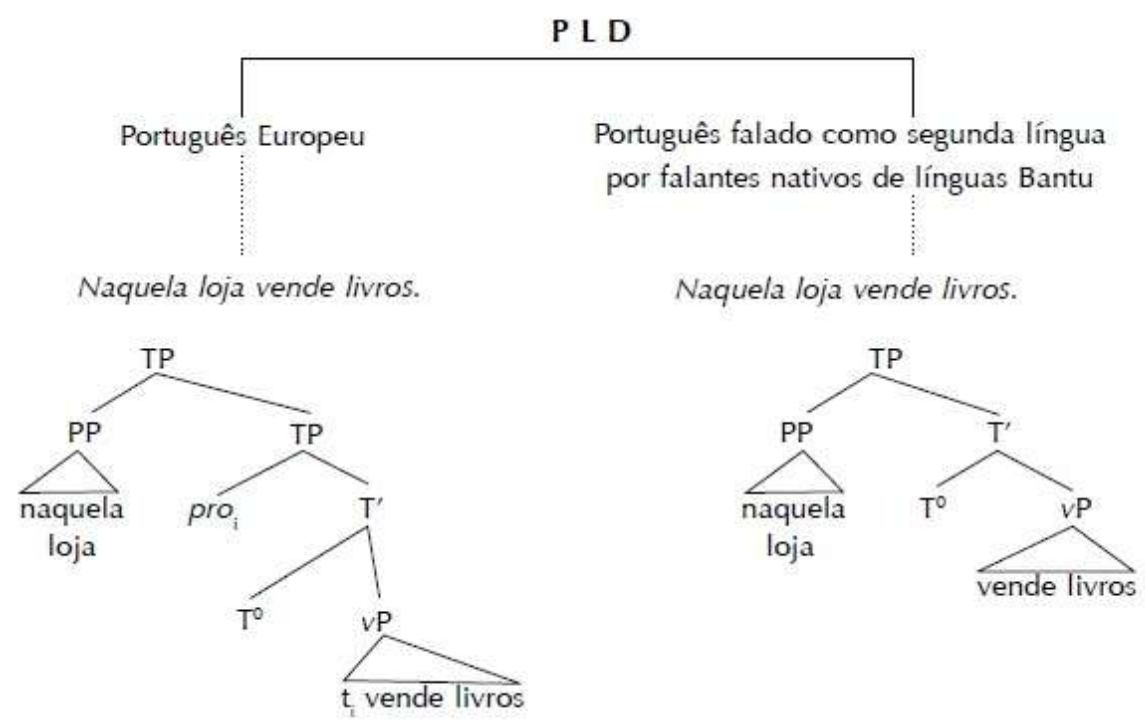

(AVELAR \& CYRINO, 2008, p. 67)

Os autores explicam que, enquanto no PE é necessário inserir, inicialmente, uma categoria nula (pro) em Spec- $v \mathrm{P}$ e depois movê-la para Spec-TP, no PB ocorre apenas a inserção do PP locativo diretamente em Spec-TP, o que seria menos oneroso para o sistema computacional. Avelar e Cyrino acrescentam ainda que o PB, diferentemente do PE, admite o licenciamento de $\mathrm{T}$ sem traços- $\phi$, por isso não há qualquer entrave para que um PP seja licenciado naquela língua.

Partindo do pressuposto de que a estrutura projetada para o PB é a mesma que as LB apresentam, Avelar \& Cyrino defendem que a falta de concordância entre verbo e locativo pré-verbal em algumas LB decorre da pobreza de traços- $\phi$ em $T$, o que permite explicar a falta de concordância verbal em (9a). Dessa forma, a inversão locativa em algumas LB não desencadeia concordância verbal, como os autores demonstram com base em mais dados das LB sesotho (11), setswana (12) e kinyarwanda (13):
(11) Mo-tsé-ng
hó-tl-il-é
ba-eti.
3-village-LOC
17-come-PRF
2-travelers

"To the village came the travelers."

(12) Mó-le-fátshé-ng gó-fúla di-kgomo

18-5-country 17SM-graze

10-cattle 
"In the country are grazing the cattle."

$\begin{array}{rlll}\text { (13) um gisagára } & \text { ha-ra-riríimbir-a } & \text { aba-shyitsi } \\ \text { in 7:village } & \text { 16-PRS-sing-IPFV } & \text { 2-guest }\end{array}$

"In the village are singing guests." (lit.)

(AVELAR \& CYRINO, 2008, p. $71-72$ )

Em suma, a argumentação de Avelar \& Cyrino é a seguinte:

\begin{abstract}
Sugerimos, preliminarmente, que as inovações do português brasileiro são o resultado do português usado como segunda língua por falantes nativos de línguas Bantu. A possibilidade de um locativo ser pré-verbal e concordar com o predicado nessas línguas, aliada ao enfraquecimento do paradigma flexional presente nos dados linguísticos primários, gerou ambiguidade para a criança que aprendia o português como primeira língua. O sintagma locativo pré-verbal, em uma posição periférica no português, é reanalisado e passa a poder figurar na posição gramatical de sujeito no português brasileiro. (AVELAR \& CYRINO, 2008, p. 55)
\end{abstract}

Na mesma linha de análise, os casos em que o locativo exerce função oblíqua em um predicado de verbo de movimento, ao qual se aplica a preposição "em", diferentemente do que prevê o PE para esse contexto, são analisados por Albuquerque \& Nascimento (2013) como uma extensão ao PB da forma de marcação locativa das LB, considerando dados do PB falado no estado de Sergipe, exemplificados a seguir.

(14) a. ... sei ki S. foi onti ni Aquidabã.

b. Se tamem mora ni kaza dus seus pais?

c. ... trabalhu kum jardinagem, ni terenu, nessas koiza.

d. Eu so vivi akilo ni minha adolesensia.

(ALBUQUERQUE \& NASCIMENTO, 2013, p. 105)

Os autores ressaltam que, ao contrário do se poderia esperar, a preposição "ni" não compõe o uso exclusivamente de falantes com baixa escolaridade, uma vez que os dados apresentados em (15), a seguir, são provenientes da fala de um entrevistado escolarizado (com o ensino fundamental completo) e residente em zona urbana. Nos dados verifica-se, inclusive, flutuação entre as formas "ni”, "na" e "em":

(15) a. Em dia atual, eu trabaio aki na sidade ni varius servisu ku animais. 
b. Paso umas koisa na tv e pensei ni ose (...) aí em fakudade.

(ALBUQUERQUE \& NASCIMENTO, 2013, p. 106)

Albuquerque \& Nascimento não só associam o morfema locativo das LB à preposição "em” do português e sua consequente seleção no argumento locativo de verbos de movimento, como também argumentam que a proximidade fonológica entre esses morfemas e a preposição "em" podem explicar a ocorrência da forma "ni”" nos dados do PB falado no estado de Sergipe. Para tanto, os autores citam os seguintes dados ${ }^{34}$ da LB changana:

$$
\begin{aligned}
& \text { (16) a. Tin-tombhi ti-hum-a [kerek-eni]. } \\
& \text { 10-rapariga 10MS-sair.de-VF 9igreja-Loc } \\
& \text { Mov+Fora+Or } \\
& \text { "As raparigas saem da igreja". } \\
& \begin{array}{rcc}
\text { b. Tin-tombhi } & \text { i-nghen-a } & \text { [kerek-eni]. } \\
\text { 10-rapariga } & \text { 10MS-entrar.em-VF } & \text { 9igreja-Loc } \\
& \text { Mov+Dentro+Dt } &
\end{array} \\
& \text { "As raparigas entram na igreja." }
\end{aligned}
$$

Os autores explicam que, nessa LB, o movimento e o percurso são lexicalizados no verbo pelo morfema “-a”, de modo que o morfema “-eni”, que acompanha o Nome locativo não interfere na descrição do movimento, diferentemente do que acontece com as preposições no português (padrão).

Para demonstrar que os morfemas locativos das LB não acrescentam interpretação conceitual acerca do movimento denotado pelo verbo, Albuquerque \& Nascimento (2013, p. 104) mencionam dados da LB tonga, na qual um único sufixo (-ni) é empregado indistintamente no locativo direcional (17a) e no situacional (17b):

(17) a. Athu anodowa omunda-ni "as pessoas vão à machamba"

\footnotetext{
${ }^{34}$ Esses dados também são apresentados em Gonçalves e Chimbutane (2004).
} 
b. Libuku lomo aba badera-ni

"o livro está na cadeira."

Embora os autores adotem a hipótese de que as propriedades das LB possam ter sido decisivas para a seleção da preposição "em”/“ni” nos dados recolhidos, eles consideram a pesquisa ainda bastante incipiente para afirmar que se trata de uma propriedade do PB como um todo.

Considerando que a hipótese de interferência de propriedades das LB na realização do locativo também é adotada por outros autores para explicar dados das demais variedades africanas do português, a próxima seção é destinada à descrição de dados que se aproximam das variedades brasileira e moçambicana do português. Com isso, pretende-se verificar até que ponto a situação de contato foi relevante para a emergência dos padrões de marcação locativa nessas variedades não-nativas da língua portuguesa.

\subsection{Realização sintática do Locativo em outras variedades africanas do português}

Nesta seção, são apresentados dados de algumas variedades africanas da língua portuguesa em que se verificam semelhanças com o PB e PM no que se refere à realização dos sintagmas locativos, especialmente à seleção da preposição que os introduz.

Nascimento et al. (2008) organizam um conjunto de dados de diversas variedades africanas do português para demonstrar aspectos em que a gramática dessas línguas tem apresentado variação em relação ao PE. Com relação aos sintagmas locativos em predicados de verbos de movimento, Nascimento et al. (2008) e Bento (2010) demonstram que a preposição "em" constitui a principal forma de marcação de argumentos locativos nas variedades do português faladas em Guiné-Bissau (18) e em Angola (19):

(18) a. "vai num hospital"

b. "qualquer dia vamos chegar num ponto"

(NASCIMENTO et al., 2008, p. 380 - 382)

(19) a. "depois se prepara ir na escola"

b. "aí você cultiva vai na tuas lavra"

c. Fui na tua casa te encontrei não estavas.

d. Consegui chegar em casa antes do telejornal da noite começar. 
e. Vou na praça fazer as compras para o jantar.

Relativamente ao português falado em São Tomé e Príncipe (PSTP), Gonçalves (2010) registra um quadro de variação um pouco diferente no que se refere ao complemento locativo dos verbos "ir" e "chegar". Segundo a autora, há duas estratégias para expressar o locativo no PSTP: i) ser o locativo um DP; ii) marcar o locativo com preposição "a" ou "em". Das duas preposições que concorrem para marcação do locativo no PSTP, os falantes marcam preferencialmente a primeira, e não a segunda, conforme exposto no seguinte gráfico:

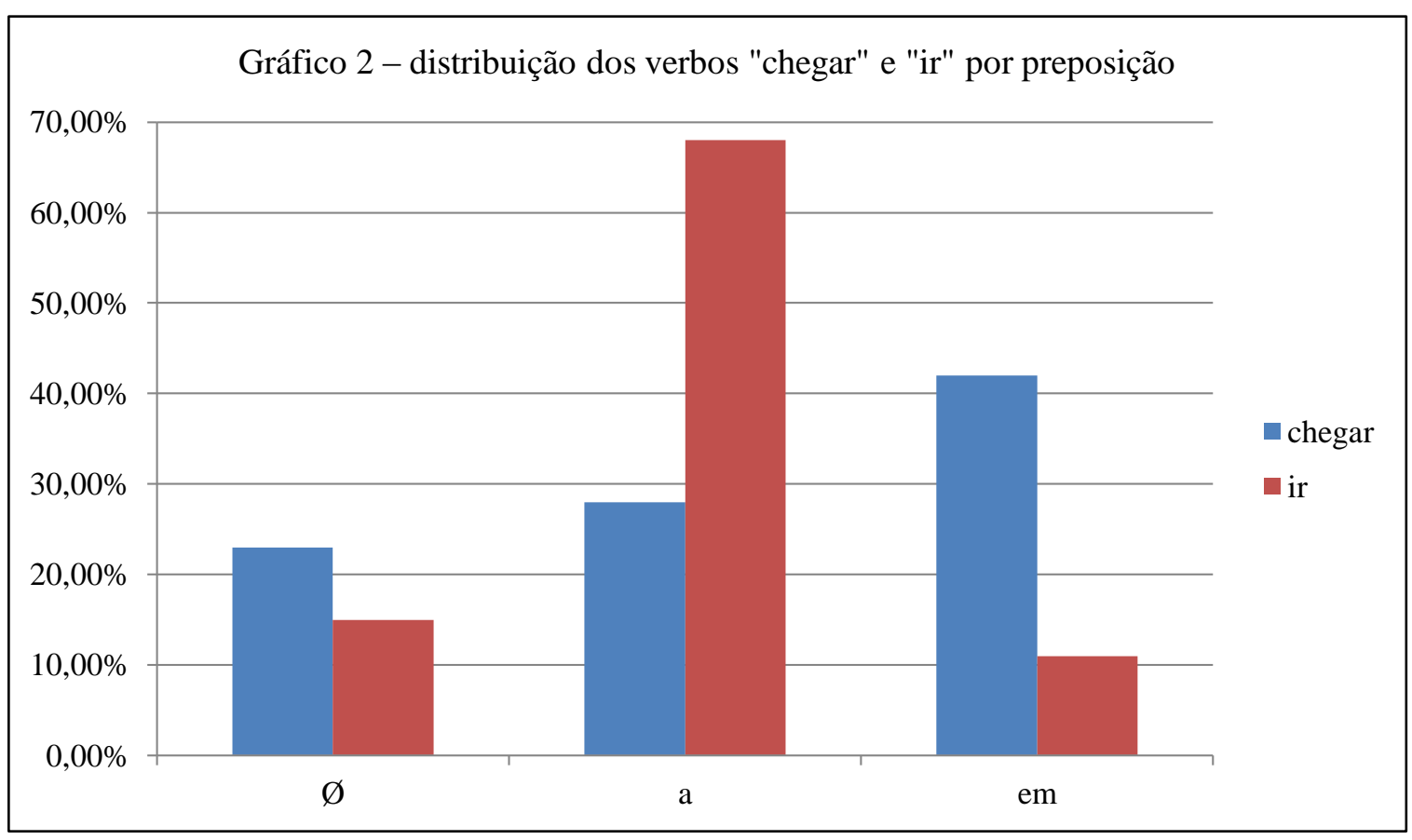

Fonte: GONÇALVES, 2010, p. 482.

Conforme se extrai do gráfico, a preposição “em” é preferível na complementação do verbo "chegar", ao passo que a preposição "a" é a estratégia mais utilizada para a marcação do argumento locativo em predicados com verbo "ir". Os dados ${ }^{35}$ apresentados por Gonçalves (2010, p. 483) ilustram essas ocorrências:

(20) a. Ao fim-de-semana vamos jogar um pouco de bola ou vamos à praia.

b. Fui a Portugal duas vezes.

\footnotetext{
${ }^{35}$ Todos os dados que a autora apresenta foram coletados de discurso oral, portanto são padrões da fala.
} 
c. Se eu trabalho, chego em casa tenho coisas para fazer.

d. A gente quando chegávamos na praia com voador (...).

Nota-se que o PSTP difere consideravelmente do detectado nas variedades africanas do português até aqui descritas. Para Gonçalves (2010), o quadro de variação em questão não se relaciona a propriedades da língua materna dos santomenses no processo de aquisição do português, uma vez que o crioulo Forro, de base lexical portuguesa, não apresenta preposições nos argumentos de verbos de movimento, de modo que a inserção da preposição locativa "ni" nesses sintagmas torna as sentenças agramaticais, segundo Gonçalves (2010, p. 484):

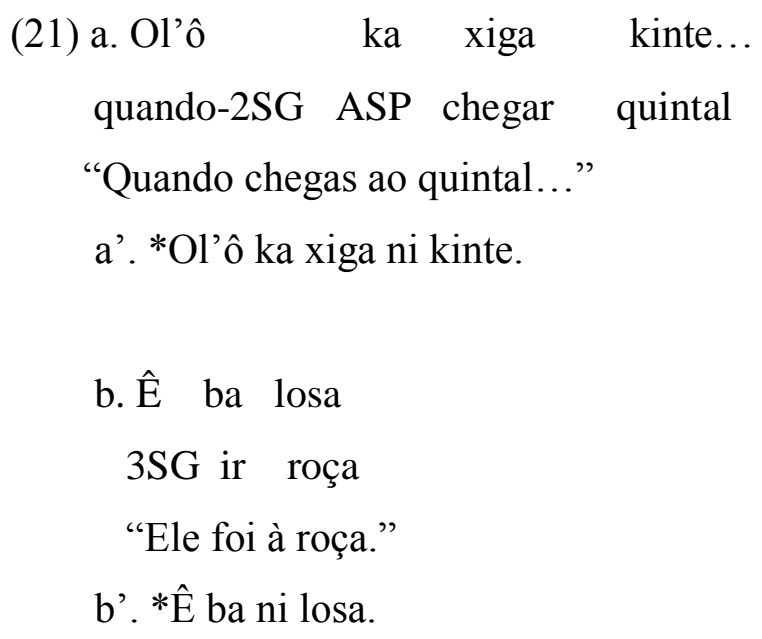

Em vista disso, Gonçalves argumenta que o que o falante analisa para selecionar a preposição introdutora de argumento locativo são as propriedades semânticas desses itens associadas ao tipo de movimento que o verbo denota. Semelhantemente ao que Mollica (1996) analisou para o PB, Gonçalves levanta a hipótese de que a preposição “em” introduz o complemento de "chegar" no PSTP devido ao aspecto télico desse movimento, que se direciona ao ponto final do deslocamento. Diferentemente, a preposição "a" focaliza o percurso do verbo "ir", sem ressaltar que o evento foi finalizado, a exemplo do padrão europeu.

Acerca dos locativos em posição pré-verbal, os estudos consultados citaram apenas os seguintes dados:

(22) Igreja eu vou mas eu vou assistir missa. (PSTP) 
(23) a. nesse sertão nosso aqui tem cascavel demais (PA)

b. no Lubango o mês de agosto tem sido quente (PA)

(SANTOS, 2011, p. 133 e 137)

Depreende-se dessa breve descrição de dados de algumas das variedades africanas do português que, embora todas tenham sido formadas a partir do contato do português com LB, há especificidades em cada uma delas que não permitem a formulação de generalizações capazes de abarcar um padrão uniforme de marcação locativa nas variedades africanas do português. Desejamos então deixá-las neste ponto apenas como evidências para futuras investigações. 


\section{CAPÍtULO 5 CONSIDERAÇÕES FINAIS}

Nesta pesquisa, constatou-se que o comportamento sintático dos sintagmas locativos no PM difere em diversos aspectos dos usos encontrados no PE. Entre esses aspectos inclui-se a seleção da preposição introdutora desse tipo de sintagma. Nos contextos em que o locativo exerce função oblíqua em predicados com verbos de movimento, o PE dispõe das preposições "a" ou "para" para a marcação do sintagma, havendo uma ligeira diferença entre elas quanto ao traço semântico [+/-permanente] do movimento, segundo Farias (2006): "a" é selecionada para indicar que o movimento é [-permanente]; "para" associa-se à interpretação de que o movimento é [+permanente].

No PM, a marcação do locativo acontece majoritariamente pela preposição "em", independentemente do tipo de verbo que compõe o predicado. Há registros também da seleção de "para" e "a", porém em número consideravelmente menor em comparação ao uso da preposição "em". Quando selecionadas, "para" e "a" também podem refletir diferenças semânticas quanto ao movimento: "para" indica movimento [+concreto] e [+permanente]; "a" denota movimento [+abstrato] e [-permanente], uma conclusão preliminar, que respaldamos em estudos que discutem esse tipo variação no PB.

Na discussão dos dados do PM, referimos a análise de Gonçalves \& Chimbutane (2004), segundo a qual o padrão de seleção da preposição "em" como introdutora de sintagmas locativos nessa língua está associado ao processo de formação dessa variedade do português. Tendo em vista o contato de línguas a partir do período colonial e acirrado recentemente com o crescimento da urbanização, o PM indica um padrão de marcação morfológica dos locativos baseado na L1/LB no processo de aquisição da L2, pelos falantes aloglotas adultos em um contexto de transmissão imperfeita, pelo qual ocorreu a reanálise das estruturas do padrão de marcação europeu, que superficialmente apresenta três possibilidades (“a”, "para" e "em”), em uma configuração que elege a preposição "em” como o mecanismo padrão de marcação desses sintagmas no PM. Por hipótese, a escolha dessa preposição teria levado em conta a proximidade fonológica dos morfemas "-eni" e "-ini”, marcadores de locativo nas LB, com a preposição portuguesa “em”, por um lado, e o caráter uniforme de marcação dos locativos por esse morfema, independentemente de uma denotação associada à noção de trajetória (o que se distingue do sistema preposicional do PE). 
Nesse sentido, assim como nas LB, os sintagmas locativos são marcados por esses morfemas, independentemente da função sintática que exerçam ou do verbo que compõe o predicado em que se inserem. Explica-se, dessa forma, que o PM tenha passado a utilizar a preposição "em” como uma categoria funcional, na estrutura de sintagmas locativos, isto é, sintagmas cujo complemento seja um DP que indique "lugar". Com esse estatuto, é possível dar conta do fato de que a preposição "em" não está associada unicamente a sintagmas locativos no PM, uma vez que esta pesquisa detectou contextos sintáticos em que se utiliza essa preposição como introdutora de sintagmas oracionais, como em "se aparecesse a guerra cada um devia estar apto em pegar arma e disparar" (Gonçalves, 1990, p. 421) e "não havia nenhuma necessidade em deixar as filhas estudar" (Gonçalves, 1990, p. 635) (embora tais estruturas não tenham sido objeto de análise mais detalhada). Esses dados revelam usos também desviantes do $\mathrm{PE}$, em que se recorre à preposição "a" e "de", respectivamente. No entanto, é significativo que o uso uniforme da preposição “em" em sintagmas locativos seja estendido a outros contextos também. Deixaremos, porém, esse assunto para pesquisas futuras, antecipando que esses dados confirmam a hipótese de que a preposição "em" no PM seja uma categoria funcional.

Conforme apresentado na seção 4.3 do capítulo 4 do presente trabalho, os resultados de estudos acerca de outras variedades africanas do português vão ao encontro da hipótese de que o contato com propriedades das LB ou das línguas crioulas formadas a partir de LB teria desencadeado padrões de marcação locativa divergentes do PE, de modo que o emprego da preposição "em" no complemento de verbos de movimento é uma das estratégias mais recorrentes de marcação do locativo no português de Guiné-Bissau (cf. Nascimento et al., 2008) e no português de Angola (cf. Inverno, 2009), por exemplo. No português de São Tomé e Príncipe, o argumento locativo de verbos de movimento, além de poder ser marcado pelas preposições “em” ou "a”, pode ser expresso sem preposição (cf. Gonçalves, 2010). Acerca dessa última estratégia, Gonçalves, (2010) levanta a hipótese de que estaria associada ao fato de que, no crioulo Forro, língua falada por mais de $70 \%$ da população santomense, a preposição marcadora de locativo (ni) não é utilizada em predicados de movimento.

Quanto ao PB, verificou-se que as preposições "para" e "em" alternam na marcação do argumento locativo de verbos de movimento. Apesar de a preposição "a" também ser selecionada nesse contexto, as pesquisas têm apontado uso preferencial daquelas em detrimento desta, cujo emprego se restringe a verbos que denotam movimento abstrato. 
Assumimos a hipótese de que a preposição “em" no PM é uma categoria funcional, realizada em uma PP shell, que codifica as propriedades expressas por operadores conceituais PLACE e PATH. Nessa configuração, a preposição funcional introduz um núcleo aspectual, que seleciona uma predicação introduzida pelo sintagma locativo (DP), que, por sua vez, pode (ou não) ser modificado por uma categoria marcadora de propriedades aspectuais.

A respeito do sintagma locativo na posição inicial da sentença, verificam-se semelhanças e diferenças entre o PB e o PM, uma vez que, nos dados da variedade moçambicana, encontramos dados que podem ser analisados como inversões locativas, e estruturas transitivas com PP locativos pré-verbais (obrigatórios), com sujeito indefinido na $3^{\mathrm{a}}$ pessoa do singular, não marcadas por 'se', também encontradas no $\mathrm{PB}$, conforme análise de Pilati (2006); Munhoz; Naves (2012) e Pilati; Naves (2013), mas não construções de tópicosujeito locativo, como as presentes (e bastante produtivas) na variedade brasileira. Finalmente, verificou-se a presença no PM de construções de cópula com verbo "estar" e PP pré-verbal, realizado, por hipótese, em posição de sujeito, ausentes no PB.

Acerca das particularidades gramaticais do PM, concordamos com a argumentação de Gonçalves \& Chimbutane (2004), segundo a qual construções de sujeito locativo presentes nas LB faladas pelos moçambicanos podem ter sido a base para um processo de reanálise envolvendo argumentos locativos na aquisição/formação inicial do PM. Como nas LB um Nome pode ser marcado morfologicamente como locativo e ocupar a posição de sujeito em predicados copulativos (estativos e atributivos), os moçambicanos falantes de LB talvez tenham estendido essa propriedade para o português, haja vista o contexto de aquisição imperfeita que, por hipótese, envolveu a formação do PM, como defendem Gonçalves \& Sitoe (1999), Gonçalves (2002), entre outros estudiosos dessa variedade do português.

As referidas diferenças entre o PM e o PB podem ser entendidas se se considera o tempo de exposição às LB e ao português nos dois países. Em Moçambique, a população falante de PE era mínima, de modo que o português foi adquirido de forma imperfeita pelos moçambicanos, o que culminou no surgimento de diversas construções mais próximas das LB desses falantes que do PE, uma vez que o input proveniente da L1/LB teria sido mais robusto. No Brasil, o contato com o português padrão ocorreu de forma mais consistente porque a coroa portuguesa mudou-se para o país, trazendo consigo um grande contingente de falantes do PE. Por isso, a estruturação da gramática do PB contou com um input robusto em traços sintáticos e semânticos do PE. No entanto, considerando que houve um momento em que havia mais africanos que portugueses nos principais centros urbanos do Brasil, a diferença 
tipológica entre as línguas africanas e o português implicou o surgimento de novas propriedades gramaticais no $\mathrm{PB}$, decorrentes, por hipótese, de processos de reanálise efetuados pelos falantes das classes mais baixas, os quais não tinham acesso ao ensino formal do idioma. Ou seja, em um contexto de aquisição imperfeita de L2, a ambiguidade dos dados da língua-alvo pode ser resolvida ou pelo acesso aos parâmetros da L1 do falante, ou pela comparação entre esses parâmetros e os parâmetros disponíveis na GU, conforme prevê a hipótese do acesso parcial à GU (White, 2003).

Tendo em vista os argumentos e os fatos empíricos levantados, a análise empreendida neste estudo contribui com a agenda de pesquisa que trata do papel das línguas africanas na formação da gramática do PB e do PM, com vistas a demonstrar como, nessas variedades, a emergência de certos fenômenos não encontrados no PE relaciona-se ao contato interlinguístico ocorrido entre no território brasileiro e no moçambicano. 


\section{Referências bibliográficas}

ALMEIDA, Napoleão M. de. (1978) Gramática latina: curso único e completo. 15. ed. São Paulo: Saraiva.

ALBUQUERQUE, Davi Borges de; NASCIMENTO, Aurelie M. F. (2013) O locativo ni na fala sergipana: uma interpretação à luz do contato de línguas. In: Interdisciplinar. Ano VIII, v.17 - Edição especial. ABRALIN/SE.

ARAÚJO, Paulo J. P. (2008) Aspectos semântico-cognitivos de usos espaciais das preposições 'para' e 'em' na fala das comunidades quilombolas. Dissertação de mestrado. Universidade de São Paulo.

ASSIS, Telma S. B. (2009) A atuação das variáveis linguísticas na regência dos verbos de movimentos no português afro-brasileiro. PAPIA, n 19, pp. $39-49$.

AVELAR, Juanito O. de. (2009) Inversão locativa e sintaxe de concordância no português brasileiro. In: Matraga, v. 16, n. 24.

AVELAR, J.; CYRINO, Sônia. (2008) Locativos preposicionados em posição de sujeito: uma posição contribuição das línguas Bantu à sintaxe do português brasileiro. Linguística 3 Revista de Estudos Linguístico da Universidade do Porto, pp. 218 - 249.

AVELAR, J.; GALVES, C. (2011) Tópico e concordância em português brasileiro e português europeu. In: A. Costa; I. Falé \& P. Barbosa (orgs.) Textos Seleccionados do XXVI Encontro Nacional da Associação Portuguesa de Linguística , pp. 49 - 65.

(2013) Concordância locativa no português brasileiro: questões para a hipótese do contato. In: M. D. Moura \& M. A. Sibaldo (orgs.). Para a História do Português Brasileiro. $1^{\text {a }}$ ed. Maceió: Edufal. pp. 103 - 132.

BAXTER, A.; MELlO, C. F.; SANTANA, N. G. de A. (2014) A construção de objeto duplo e as influências do substrato no português afrobrasileiro (e africano). In: PAPIA, 24(2), pp. $283-306$.

BENTO, Cristina T. J. S. F. (2010) Contributos para uma caracterização linguística do luandense. Dissertação de mestrado. Universidade de Aveiro, Portugal.

BERLINCK, Rosane de A. (2001) Dativo ou Locativo? Sobre sentidos e formas do "dativo" no português. In: Revista Letras, n. 56, pp. 159 - 175.

BRITO, Ana M. (2002) Relativas no genitivo "estranhas" no português de Moçambique: Erros ou sinais de mudança? In: As Ciências Sociais nos Espaços de Língua Portuguesa: Balanços e desafios. Actas, 2, pp. 329 - 336. Porto: Universidade do Porto, Faculdade de Letras.

(2008) Grammar variation in the expression of verb arguments: the case of the Portuguese Indirect Object. Phrasis, v. 2, 2008, p. 31 - 55.

BURZIO, L. (1986). Italian Syntax: a government-binding approach. Dordrecht: Reidel.

CANÇADO, M. (2009) Argumentos: complementos e adjuntos. São Paulo: Alfa, 53 (1), pp. $35-59$.

CARVALHO, Maria José Albarran (1991) Aspectos sintáctico-semânticos dos verbos locativos no Português oral de Maputo. Lisboa: I.C.A.L.P./Angolê - Artes e Letras. 
CASTRO, Yeda P. de. (2006) A matriz africana no português do Brasil. In: CARDOSO, S. A. M.; MOTA, J. A.; MATTOS e SILVA, R. V. (orgs) Quinhentos anos de história linguística do Brasil. Salvador: Secretaria de Cultura e Turismo do Estado da Bahia. pp. 81 - 115.

CHIMBUTANE, F. (1995) A estratégia do pronome resumptivo na formação de orações relativas restritivas de objecto directo e de oblíquo do português de Moçambique. Tese de licenciatura. Universidade Eduardo Mondlane.

CHOMSKY, N. (1959) A review of B. F. Skinner's Verbal Behavior 1957. In: Language. 35, pp. $26-58$.

(1981) Lectures on government and binding. Dordrecht: Foris.

(1986) Knowledge of Language: its nature, origin and use. New York:

Praeger.

(1995) The Minimalist Program. Cambridge. Mass.: MIT Press.

(1998) Linguagem e mente. Brasília: Editora UnB.

(2008) On phases. In: FREIDIN, R.; OTERO, C. P.; ZUBIZARRETA, M. L. (ed.) Foundation issues in linguistic theory: essays in honor of Jean-Roger Vergnaud. Cambridge: MIT Press, pp. 133 - 166.

COSTA, João. (2010) PB e PE: orientação para o discurso importa? In: Estudos de Lingua(gem). v. 8. n. 1. pp. $123-143$.

CUNHA, C. \& CINTRA, L. (1985) Nova gramática do português contemporâneo. 2 ed. São Paulo: Nova Fronteira.

DUARTE, Inês. (1987) A construção de topicalização na gramática do Português. Dissertação de doutoramento. Universidade de Lisboa.

DUARTE, Inês; GONÇALVES, Anabela; MIGUEL, Matilde; MOTA, Maria Antónia (1998) Não cheguei de aprender nada - Áreas de variação e tendências de mudança no português de Moçambique. In: LOPES, Ana C.; MARTINS, Cristina. (orgs.) Actas do XIV Encontro Nacional da Associação Portuguesa de Linguística. Lisboa: Associação Portuguesa de Linguística, pp. 477 - 493.

DUARTE, I.; BRITO, A. M. (2003) Predicados e classes de predicadores verbais. In: MATEUS, M. H. M. et al. Gramática da Língua Portuguesa. 5. ed. Lisboa: Editorial Caminho, 2003, pp. $181-203$.

ENDRUSCHAT, Annette. (2004) Elementos preposicionais nas línguas crioulas de base portuguesa. In: PAPIA. v. 14, pp. $47-70$.

EUGENIO SOUTO, K. C. (2014) Categorias funcionais e lexicais no licenciamento dos verbos de trajetória: o caso do verbo 'ir'. Tese de doutoramento. Universidade de Brasília.

FÁBREGAS, A. (2007). An exhaustive lexicalisation accout for directional complements. CASTL, University of Tromso. Disponível em: http://uit.academia.edu/AntonioF\%C3\%A1bregas/Papers/525956/An_exhaustive_lexicalisatio n_account_of_directional_complements> Acessado em: 09 de fevereiro de 2012.

FARIAS, Jair G. (2006) Variação entre a, para e em no português brasileiro e no português europeu: algumas notas. Porto Alegre: Revista Letras de Hoje, vol. 41, nº 1, pp. 213 - 234.

FIRMINO, Gregório (2000). A Situação Linguística de Moçambique: Dados do II Recenseamento Geral da População e Habitação de 1997. Maputo: INE. 
GALVES, Charlotte. (1998) Tópicos, sujeitos, pronomes e concordância no português brasileiro. In: Caderno de Estudos Linguísticos. n. 34, pp. 19 - 32.

(2008) O papel das línguas africanas na formação do português brasileiro: (mais) pistas para uma nova agenda de pesquisa. In: Gragoatá. n. 24, pp. 145 - 164.

GOMES, Christina A. (1997) A importância do significado da preposição na aquisição de segunda língua. PAPIA, v. 9, pp. $65-71$.

GONÇALVES, Perpétua. (1990) A construção de uma gramática de português em Moçambique: aspectos da estrutura argumental dos verbos. Dissertação de doutoramento. Universidade de Lisboa.

(2002) The role of ambiguity in second language change: the case of Mozambican African Portuguese. Second Language Research, no 18, pp. 325 - 347.

(2005) Falsos sucessos no processamento do input na aquisição de L2: papel da ambiguidade na génese do português de Moçambique. Revista da ABRALIN. v. IV, n. 1 e 2 , pp. $47-73$.

GONÇALVES, Perpétua; CHIMBUTANE, Feliciano. (2004) O papel das línguas Bantu na gênese do português de Moçambique: o comportamento sintáctico de constituintes locativo e direcionais. In: PAPIA, $\mathrm{n}^{\circ} 14$, p. $7-30$.

GONÇALVES, P; SITOE, B. (1999) Mudança linguística em situação de contacto de línguas: o caso do Changana e do português. In: Travessias. v. I. Rio de Janeiro, pp. 73 - 86.

GONÇALVES, Rita. (2010) A preposição a no português de S. Tomé. In: Textos Seleccionados do XXV Encontro Nacional da Associação Portuguesa de Linguística. Lisboa: Edições Colibri, pp. 475 - 486.

(2011) Functional prepositions and argument structure in Santomean Portuguese. (pôster). Creole Seminar. Lisboa: FCSH-UNL.

HOLM, J. (1987) Creole influence on popular Brazilian Portuguese. In: G. Gilbert (org.). Pidgin and creole languages: essays in memory of john E. Reinecke. Honolulu: University of Hawaii Press, pp. 406 - 429.

HORNSTEIN, N., J. NUNES e K.K. GROHMANN. (2005) Understanding Minimalism. New York: Cambridge University Press.

INVERNO, Liliane. (2009) Contact-induced restructuring of Portuguese morphosyntax in interior Angola. Tese de Doutoramento. Faculdade de Letras da Universidade de Coimbra.

JACKENDOFF, Ray. (1972) Semantic Interpretation in Generative Grammar. Cambridge: MIT Press.

(1983) Semantics and Cognition. Cambridge, MA: MIT Press.

LEVIN, B. \& RAPPAPORT, H. (1995) Unaccusativity at the Syntax-Lexical Semantics Interface. Cambridge, Mass., MIT Press.

LEWIS, M. Paul; SIMONS, Gary F.; FENNIG, Charles D. (eds.). (2016) Ethnologue: Languages of the World. $19^{\text {th }}$ ed. Dallas, Texas: SIL International. http://www.ethnologue.com

LITTLEFIELD, H. (2005) Lexical and Functional Prepositions in Acquisition: Evidence for a Hybrid Category. Conference on Language Development, 29, Boston University. Disponível 
em: http://www.bu.edu/bucld/files/2011/05/29-LittlefieldBUCLD2004.pdf (acesso em: 10/07/2016)

LOBATO, L. (1995) De novo sobre advérbios e preposições, sintagmas adverbiais e sintagmas preposicionais. In: HEYE, Jügen (org). Flores verbais: uma homenagem linguística e literária para Eneida do Rego Monteiro Bomfim no seu $70^{\circ}$ aniversário. Rio de Janeiro: Ed. 34, 1995. pp. 23 - 39.

LUCCHESI, Dante. (2001) A questão da formação do português popular do Brasil: um estudo de caso. In: Cor das Letras. Feira de Santana, pp. 73 - 100.

(2003) O conceito de transmissão linguística irregular e o processo de formação do português do Brasil. In: RONCARATI, Claudia; ABRAÇADO, Jussara (orgs.). Português brasileiro: contato linguístico, heterogeneidade e história. Rio de Janeiro: 7 Letras, pp. $272-284$.

MATEUS, M. H. M. et al. (2003) Gramática da Língua Portuguesa. 5. ed. Lisboa: Editorial Caminho.

MATTOS e SILVA, R. V. (2002) Para a história do português culto e popular brasileiro. In: T. Alkmim (org.). Para a história do português brasileiro, Vol. III. São Paulo: Humanitas, pp. $443-464$.

MIOTO, Carlos; FIGUEIREDO SILVA, Ma Cristina; LOPES, Ruth E. V. (2005) Novo Manual de Sintaxe. $2^{\mathrm{a}}$ ed., Florianópolis: Insular.

MIYAGAWA, S. (2010) Why agree? Why move? Unifying agreement-based and discourseconfigurational languages. Cambridge: MIT Press (Linguistic Inquiry Monographs, 54).

MOLLICA, Maria C. M. (1996) A regência variável do verbo "ir" de movimento. In: SILVA, Giselle M. O.; SCHERRE, Maria Marta P. (Orgs.). Padrões sociolinguísticos: análise de fenômenos variáveis do português falado na cidade do Rio de Janeiro. Rio de Janeiro: Tempo Brasileiro.

MUNHOZ, Ana T. M. (2011) A estrutura argumental das construções de tópico-sujeito: o caso dos sujeitos locativos. Dissertação de mestrado. Universidade de Brasília.

MUNHOZ, Ana T. M.; NAVES, Rosana R. (2012) Construções de tópico-sujeito: uma proposta em termos de estrutura argumental e de transferência de traços de C. In: Signum. n. $15 / 1$, pp. $245-265$.

MUSSA, Alberto. (2001) O papel das línguas africanas na história do português do Brasil. Dissertação de Mestrado. Universidade Federal do Rio de Janeiro.

NARO, A.; SCHERRE, M. M. (2007) Origens do Português Brasileiro. São Paulo: Parábola.

NASCIMENTO, M ${ }^{\mathrm{a}}$ F. et al. (2008) Corpus África: as cinco variedades africanas do português. In: Textos Seleccionados do XXIII Encontro Nacional da Associação Portuguesa de Linguística. Lisboa: APL, pp. 373 - 384.

NGUNGA, A. (2009) Empréstimos nominais de português em Bantu: o caso da língua yao. In: GALVES, C.; GARMES, H.; RIBEIRO, F. R. (Org.). África-Brasil: caminhos da língua portuguesa. S. Paulo: Editora da Unicamp, pp. 185 - 209.

OLIVEIRA, Marilza. (2008) Português Brasileiro, Português Moçambicano e as línguas crioulas de base portuguesa. In: Veredas. n. 9, pp. $99-113$. 
PETTER, M. T. (2006) Línguas africanas no Brasil. In: CARDOSO, S.; MOTA, J., MATTOS e SILVA, R. V. (orgs.). Quinhentos anos de história linguística do Brasil. Salvador: Secretaria da Cultura e Turismo do Estado da Bahia, pp. 117 - 142.

(2007) Uma hipótese explicativa do contato entre o português e as línguas africanas. PAPIA - Revista Brasileira de Estudos Crioulos e Similares. 17, pp. 9-19.

(2008) Variedades linguísticas em contato: português angolano, português brasileiro e português moçambicano. Dissertação de doutorado. São Paulo: USP Departamento de Linguística.

(2009) Aspectos morfossintáticos comuns ao português angolano, brasileiro e moçambicano. PAPIA - Revista Brasileira de Estudos Crioulos e Similares. 19, pp. 201-220.

PERLMUTTER, D. (1978) Impersonal Passives and the Unaccusative Hypothesis. In: Proceedings of the 4th Annual Meeting of the Berkeley Linguistics Society. Berkeley Linguistics Society, Berkeley, pp. $157-189$.

PILATI, Eloísa. (2006) Aspectos sintáticos e semânticas das orações com ordem VerboSujeito no português do Brasil. Tese de doutoramento. Universidade de Brasília.

PILATI, E.; NAVES, R. R. (2010) A hipótese de transferência de traços e o licenciamento da posição de sujeito no português do Brasil. In: Ciclo de Palestras - Temas em Teoria Gerativa, 7. Brasília: Universidade de Brasília.

PONTES, E. L. (1986). Sujeito: da sintaxe ao discurso. São Paulo: Ática; (Brasília): INL, Fundação Nacional Pró-Memória.

(1987) O tópico no português do Brasil. Campinas: Pontes.

PRATAS, F. (2007) Tense features and argument structure in Capeverdean predicates. Tese de Doutoramento. Universidade Nova de Lisboa.

RABÊLO, S. (2014) Mudança categorial da preposição 'em' no processo de aquisição do português de Moçambique. Comunicação apresentada no I Encontro Internacional e VII Encontro Nacional do Grupo de Estudos de Linguagem do Centro-Oeste. Universidade Estadual de Goiás, 29 de agosto de 2014.

RABÊLO, S. F.; SALLES, H, M. M. L. (2013) Estudo comparativo de sintagmas locativos e dativos no português brasileiro, europeu e de Moçambique. In: Anais do $19^{\circ}$ Congresso de Iniciação Científica da UnB e $10^{\circ}$ Congresso de Iniciação Científica do DF. v. 3. Livro de Resumos. Universidade de Brasília, 2013, p. 344. Disponível em: http://www.unb.br/administracao/decanatos/dpp/dific/anais/2013/Resumo\%20ProIC2013\%20-\%20Vol\%203.pdf (Acesso em 26/07/2016).

REITE, Torun. (2013) ̀̀ descoberta de particularidades no português de Moçambique: explorações quantitativa e comparativa. Dissertação de mestrado. Universidade de Oslo.

ROBERTS, Ian. (1997) Comparative Syntax. Great Britain; Arnold. (2007) Diachronic Syntax. Oxford University Press.

ROCHA, Ana P. (2005) Uso de preposições no português como L2: verbos de movimento. Brasília: Anais do IV Congresso Internacional da ABRALIN, pp. 159 - 164.

SALleS, H. M. L. (1992) Prepositions and the Syntax of Complementation. PhD Thesis. University of Wales. 
TARALLO, F. (1990) Tempos linguísticos. Itinerário histórico da língua portuguesa. São Paulo: Ática.

TORTORA, Christina. (1996) Two types of unnacusatives: evidence from a Nothern Italian dialect. In: ZAGONA, Karen. Grammatical theory and Romance languages. Select papers from the 25th Linguisctic Symposium on Romance Languages. Amsterdam: John Benjamins, pp. $251-262$.

(1997) The syntax and semantics of the weak locative. Tese de doutoramento. Department of Linguistics and Cognitive Science. University of Delaware.

(2008) Aspect inside PLACE PPs. In: ASBURY, Anna; DOTLACIL, Jakub; GEHRK, Berit; NOUWEN, Rick. (orgs.) Syntax and semantics of spatial P. Amsterdam: John Benjamins, pp. $273-301$.

VAN HOECKE, W. (1996) The Latin dative. In: BELLE, W. V.; LANGENDONCK, W. V. The Dative - Volume 1: Descriptive studies. Amsterdam: John Benjamins, pp. 3 - 38. Disponível em: https://books.google.com.br/books?id=vSVzAAAAQBAJ\&printsec=frontcover\&hl=pt-

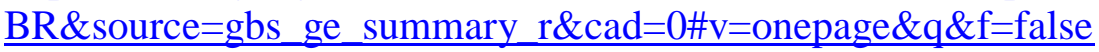

VIEIRA, Maria J. B. (2009) Variação das preposições em verbos de movimento. Londrina: Signum Estudos Linguísticos, v. 12, nº 1, p. 423 - 445.

WHITE, L. (2003) Second language acquisition and Universal Grammar. Cambridge University Press. 